
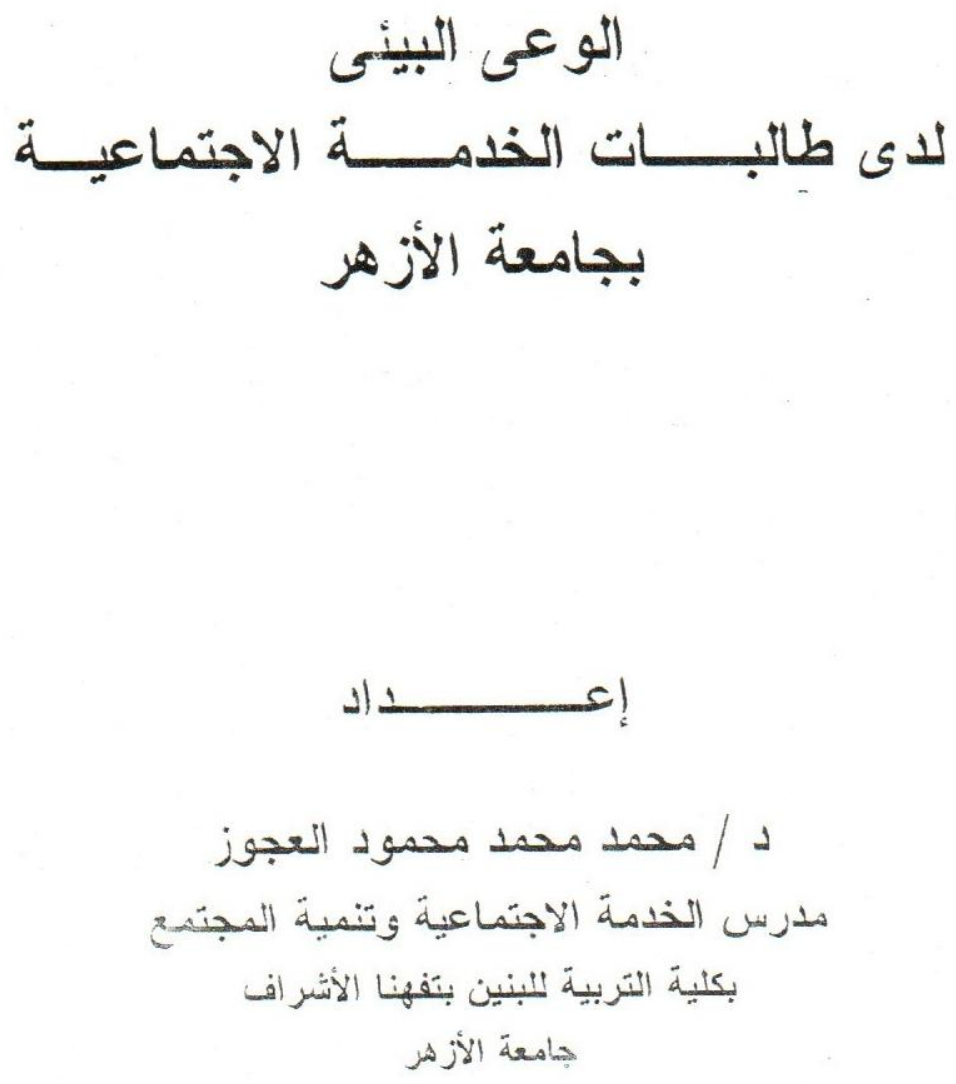

r... 


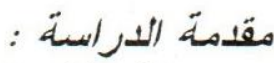

منذ نشأة الإنسان : على الأرض وهو فو فى تفاعل دائم مع البينة

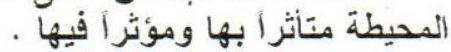

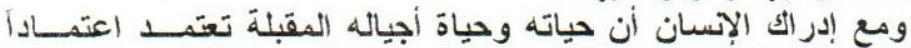

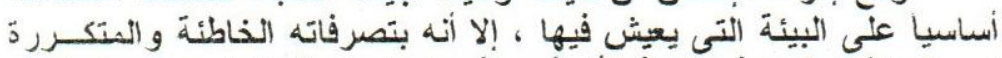

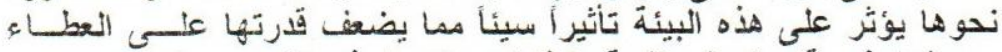

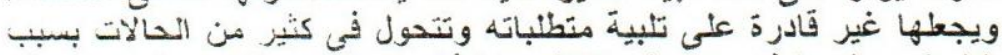

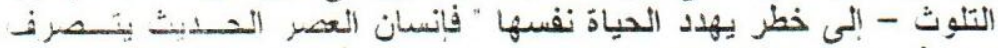

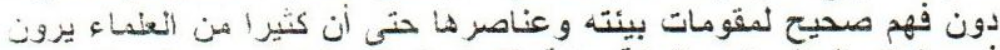

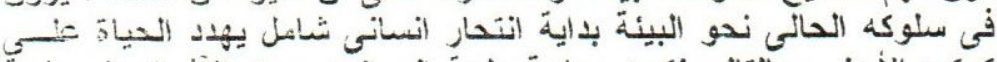

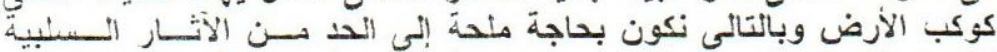

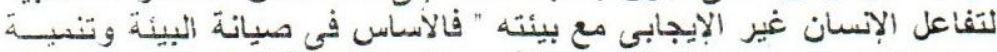

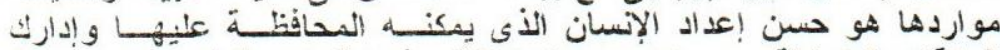

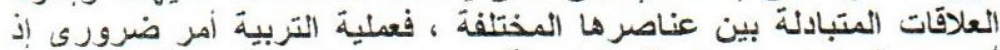

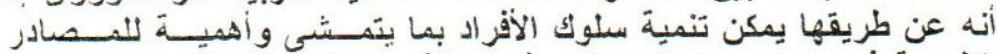

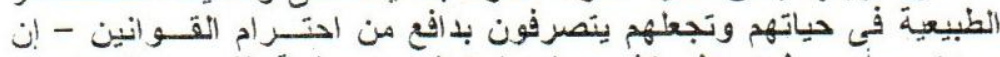

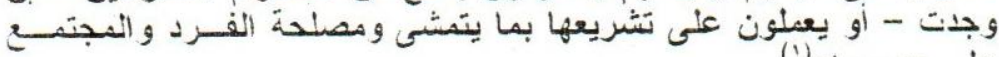

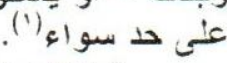

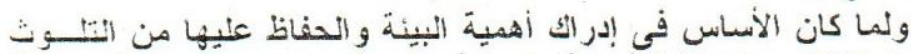

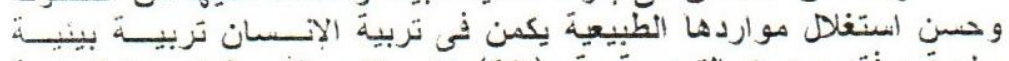

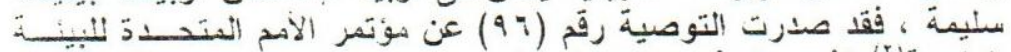

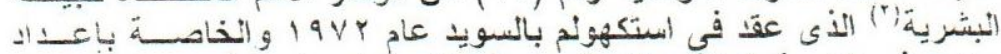

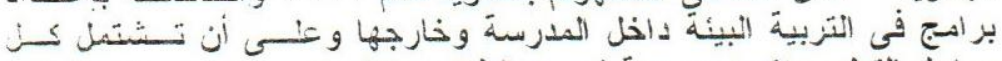

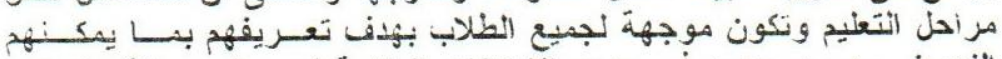

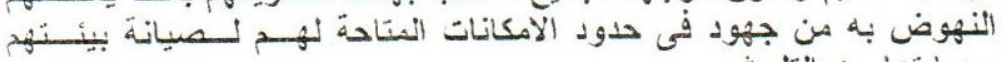

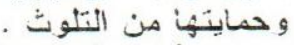

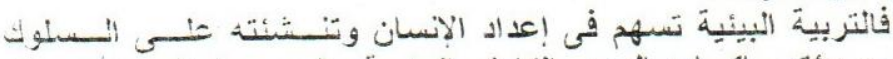

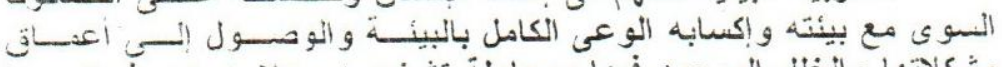

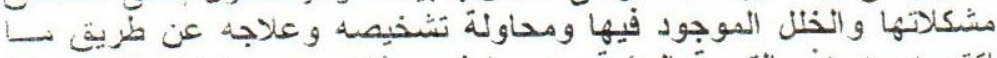

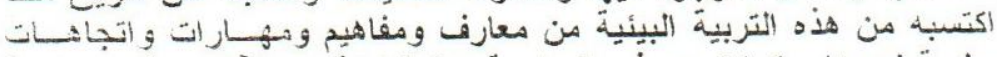

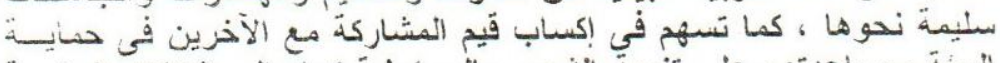

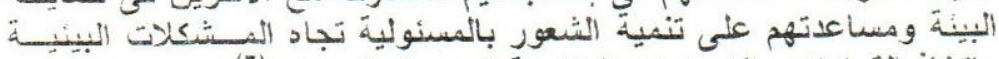

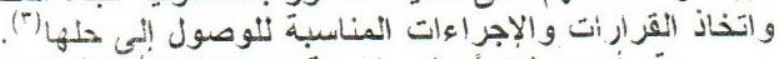

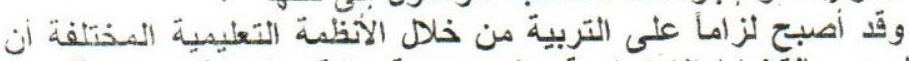

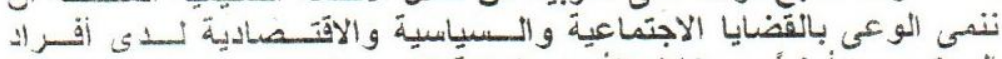

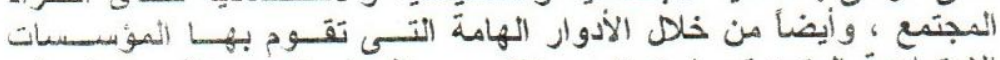

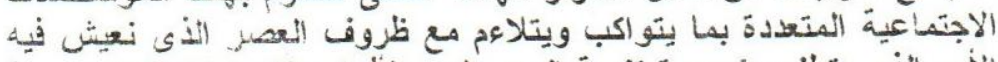

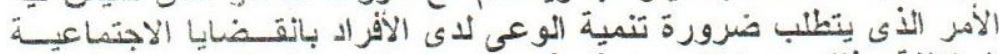

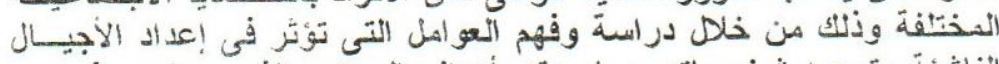

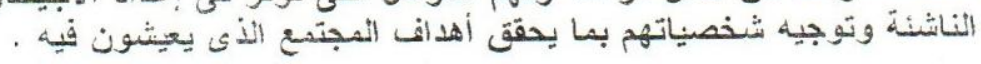




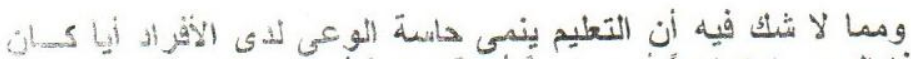

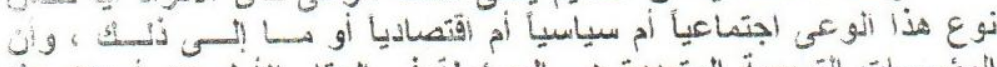

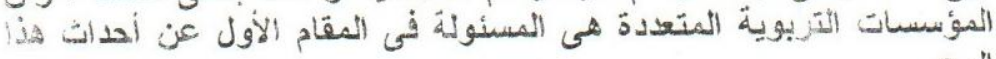

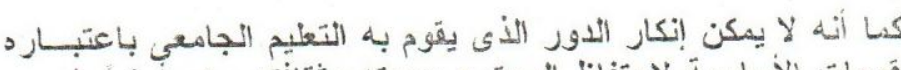
الؤوعى

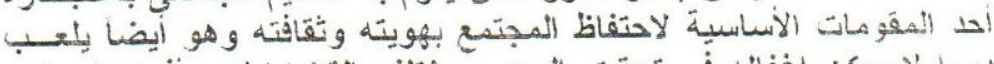

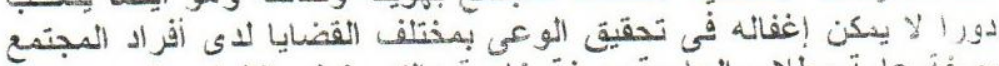

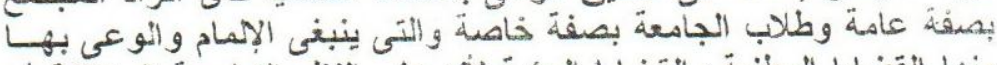

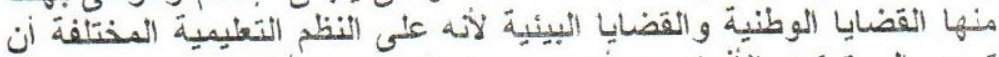

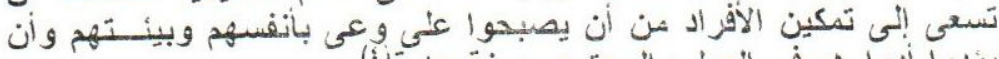

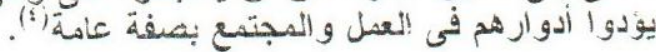

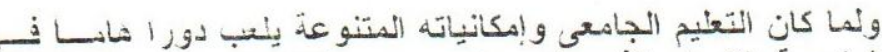

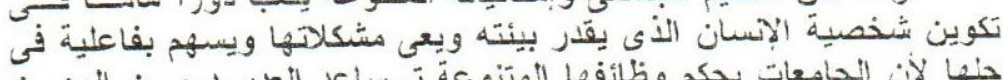

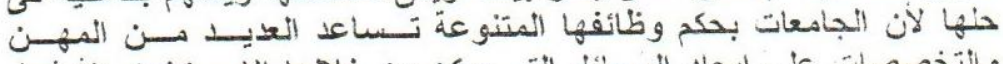

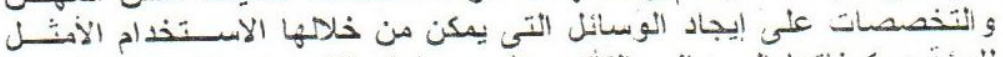

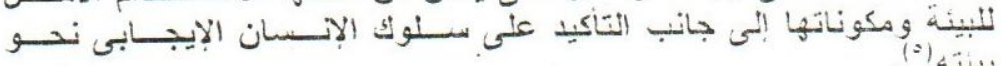

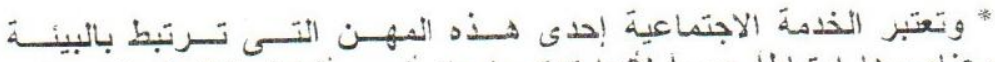

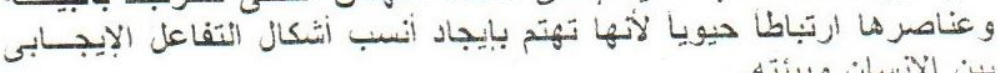
بين الإنسان وبيئته.

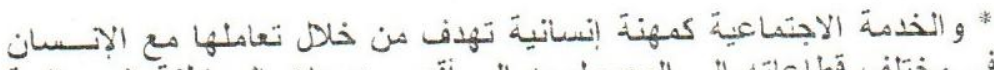

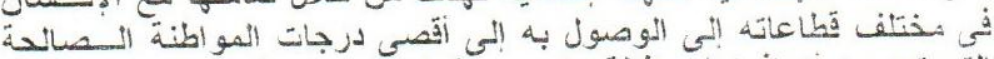

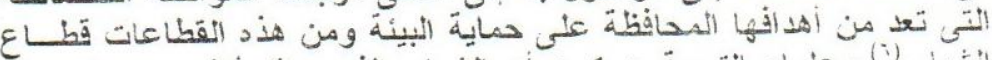

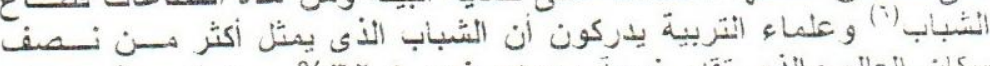

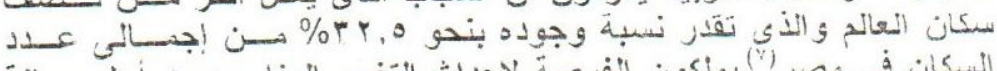

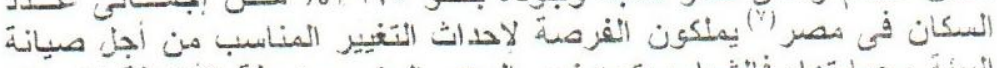

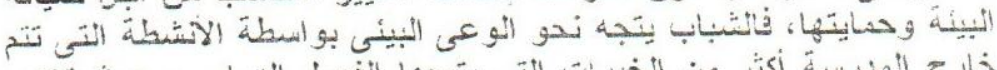

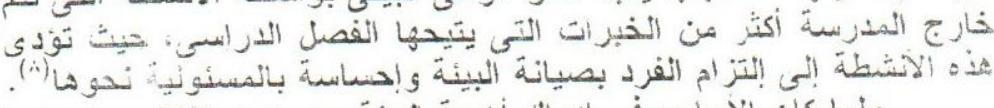

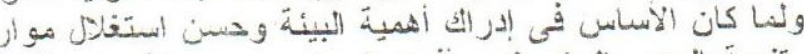

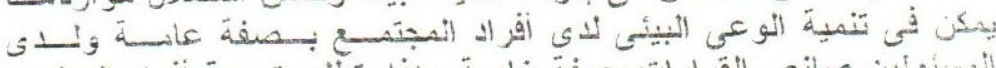

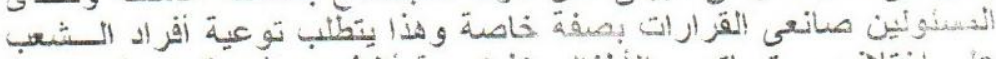

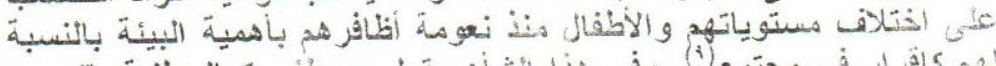

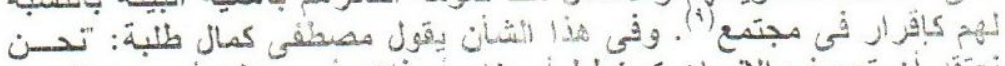

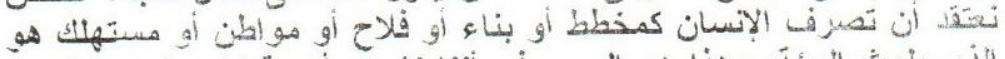

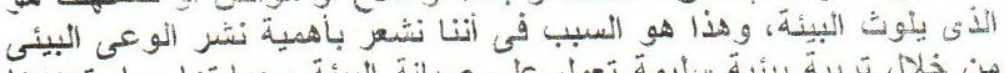

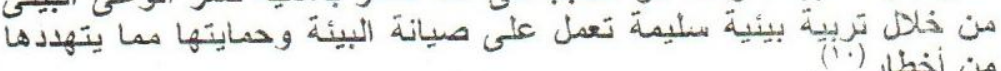




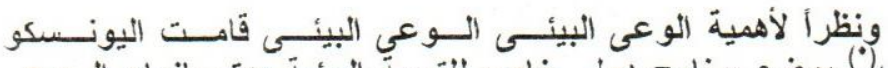

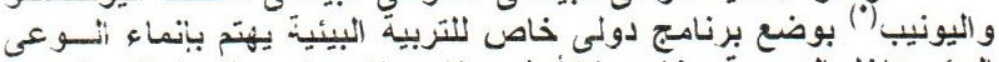

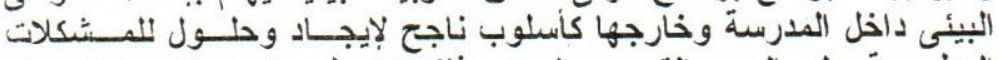

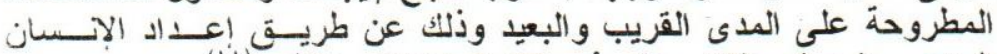

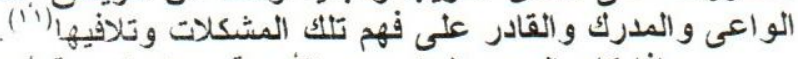

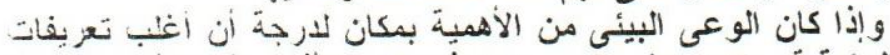

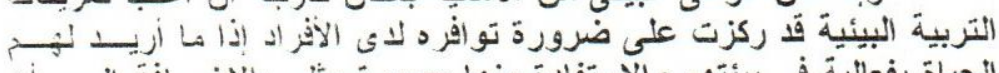

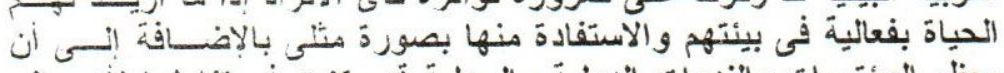

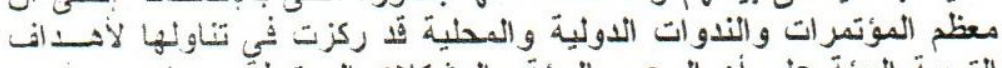

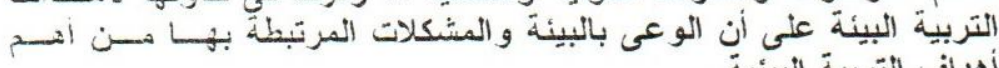
أهداف التربية البينة النبيئية. أنسا.

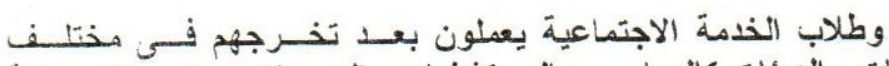

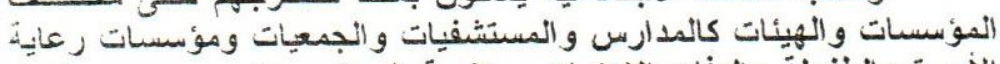

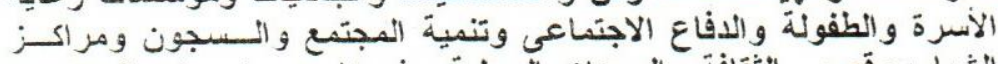

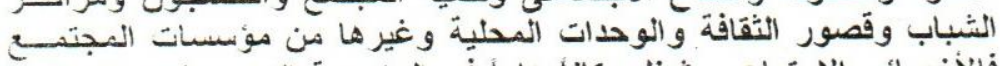

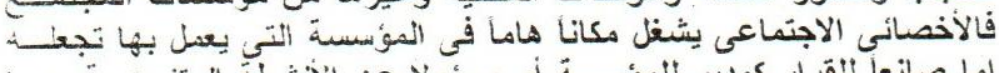

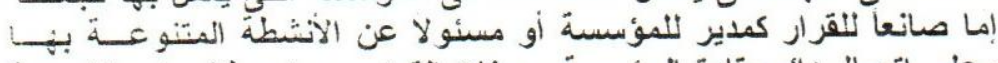

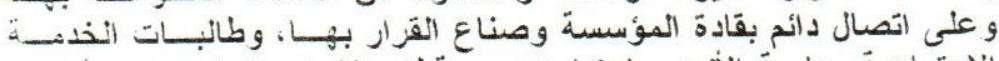

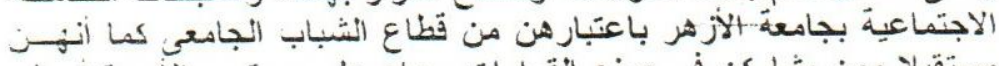

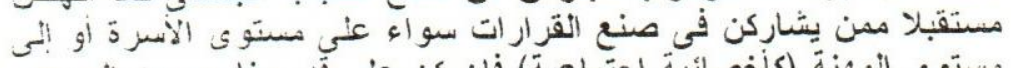

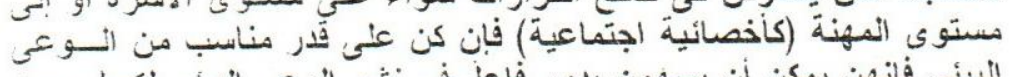

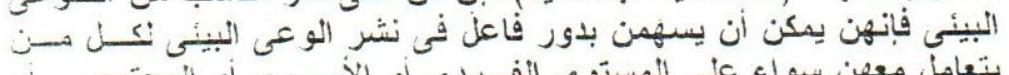

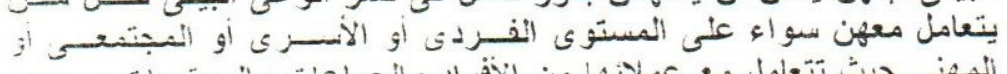

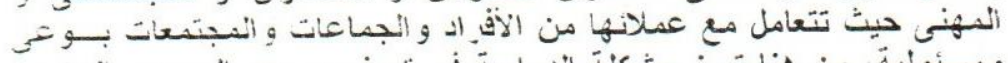

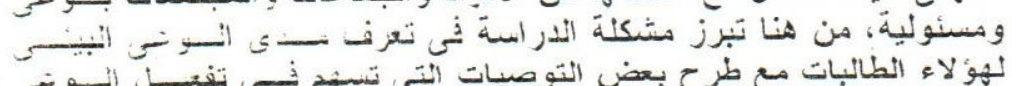

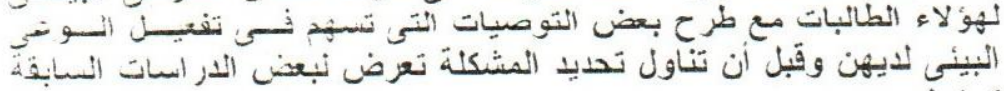
كنانيفي r - الادرانسات السيابقة:

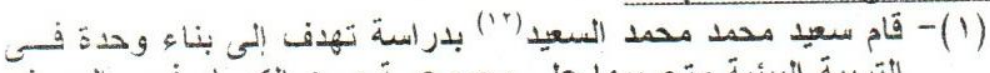

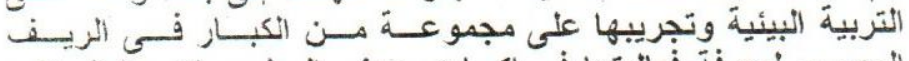

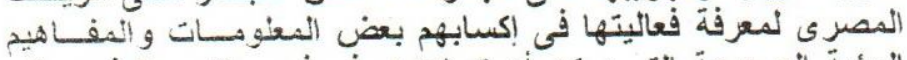

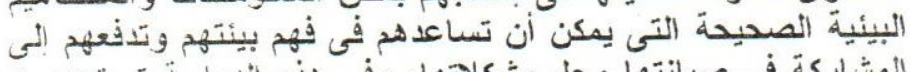

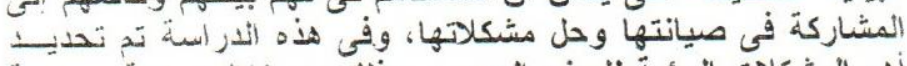

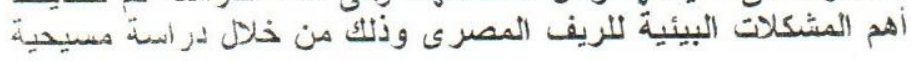

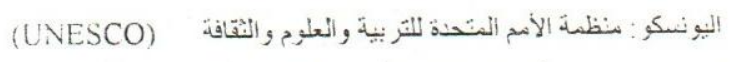

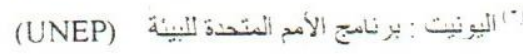




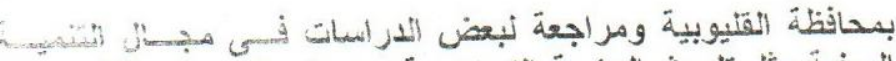

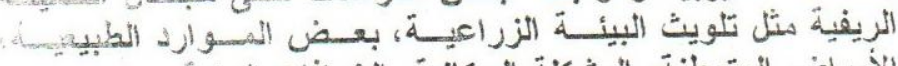

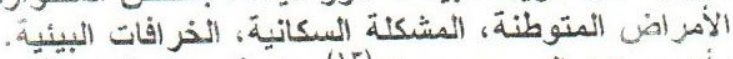

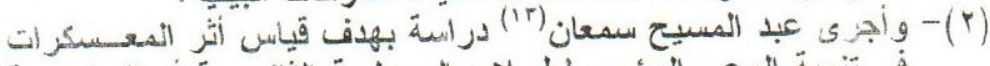

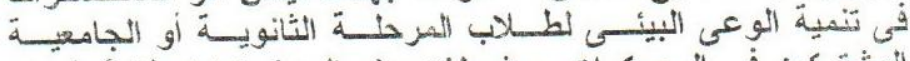

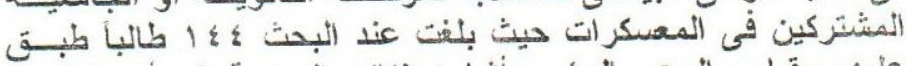

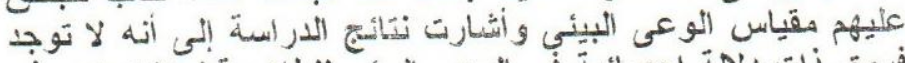

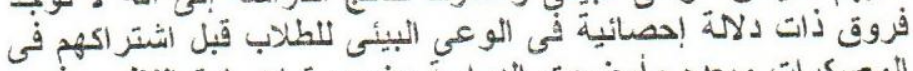

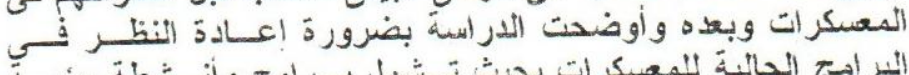

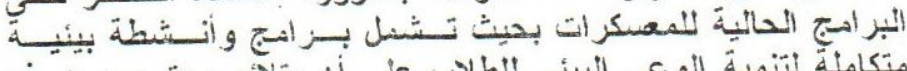

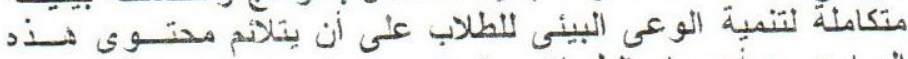

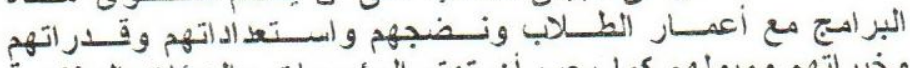

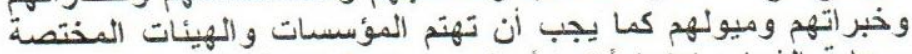

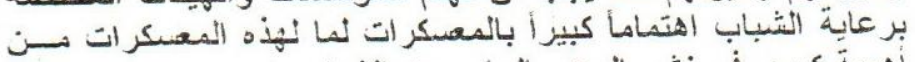

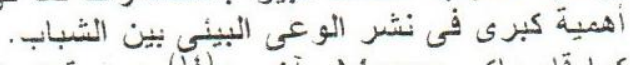

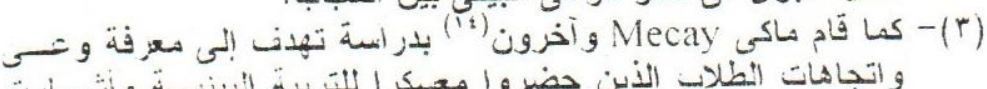

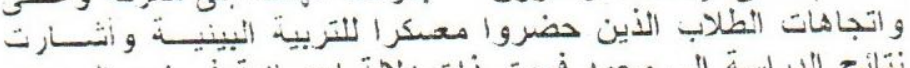

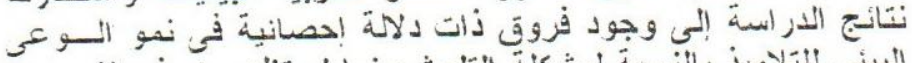

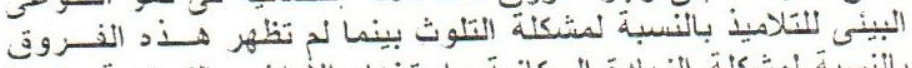

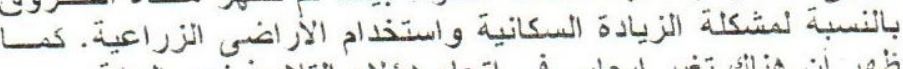

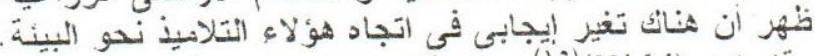

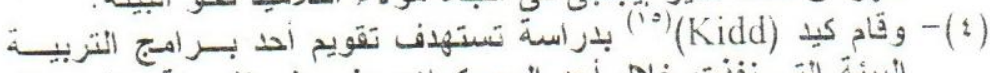

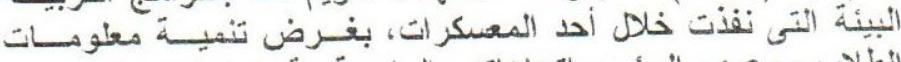

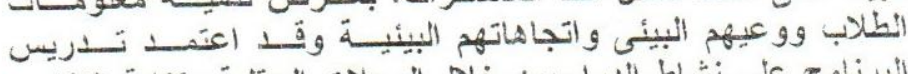

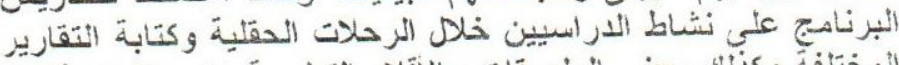

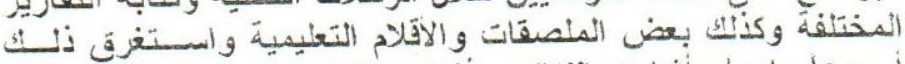

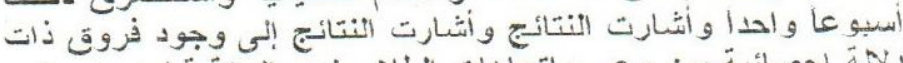

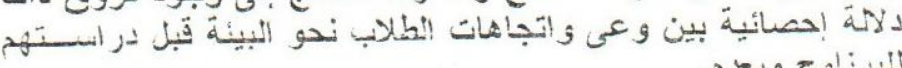

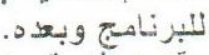

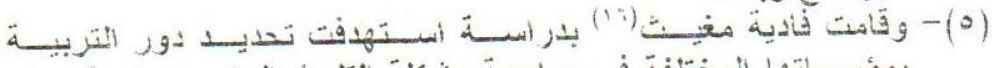

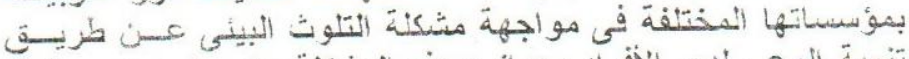

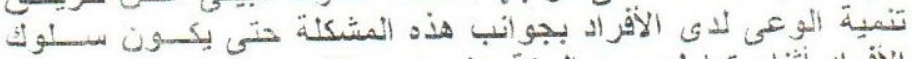

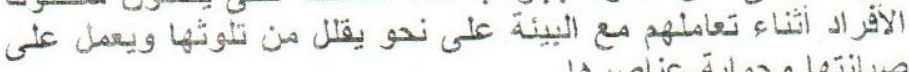

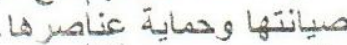

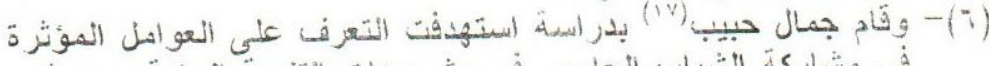

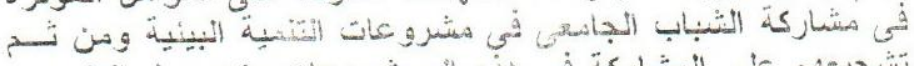

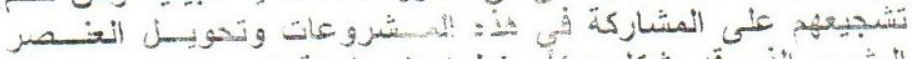

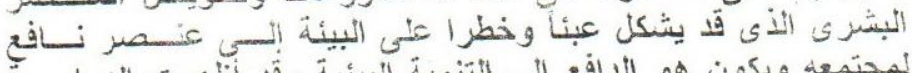

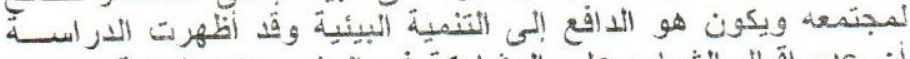

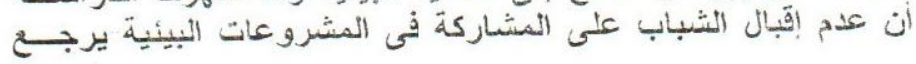




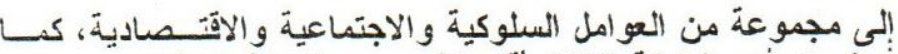

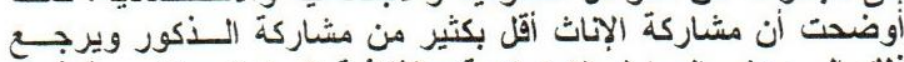

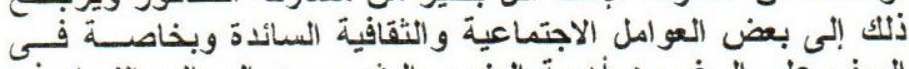

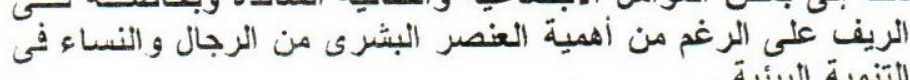

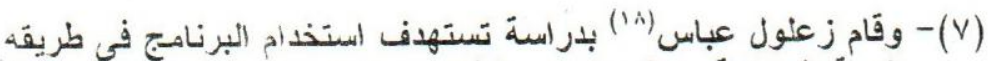

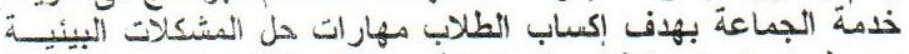

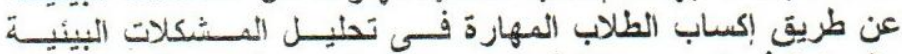

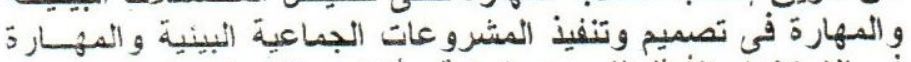

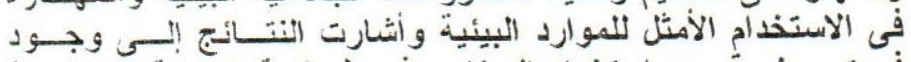

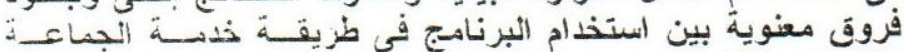

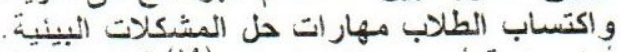

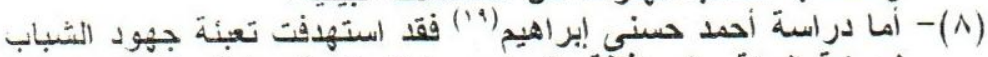

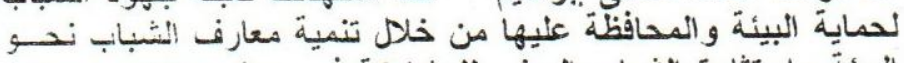

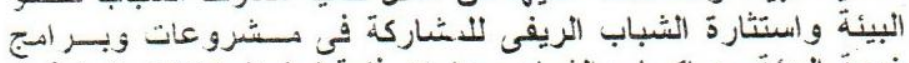

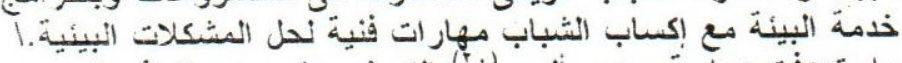

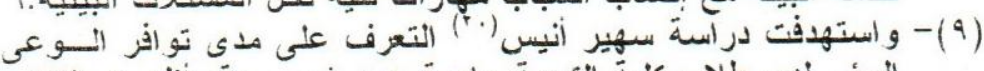

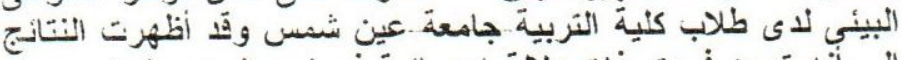

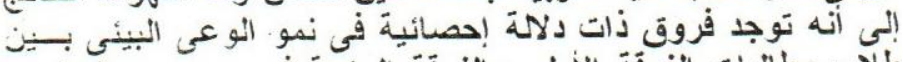

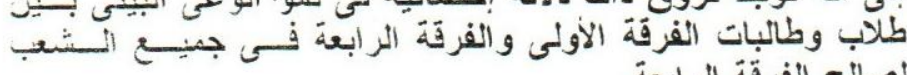

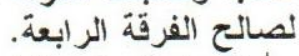

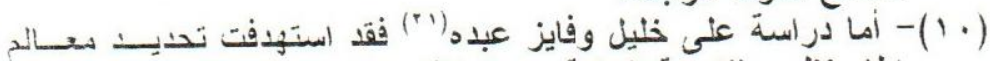

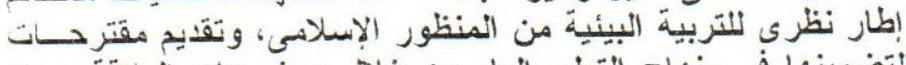

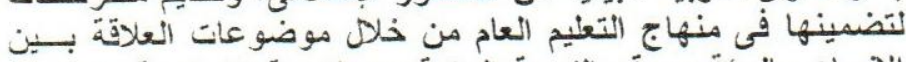

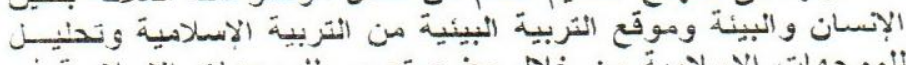

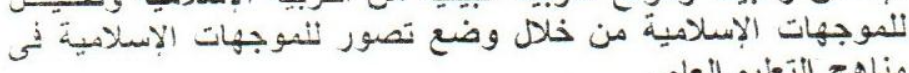

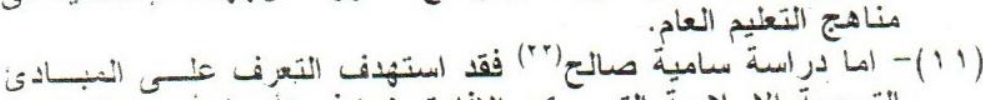

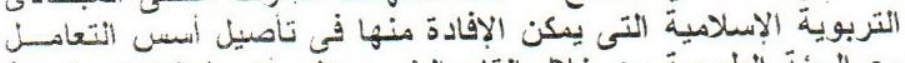

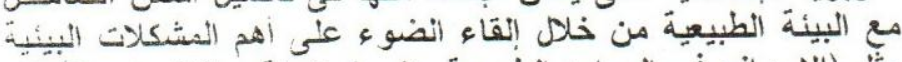

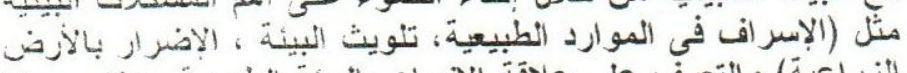

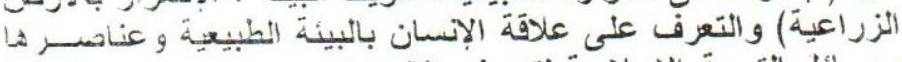

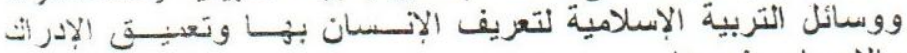

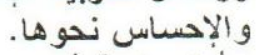

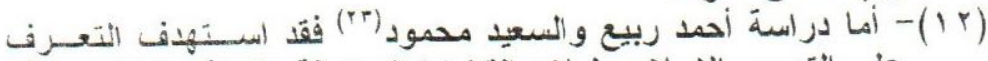

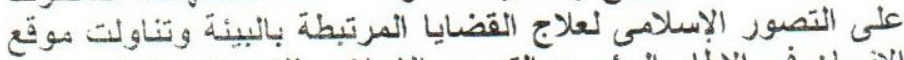

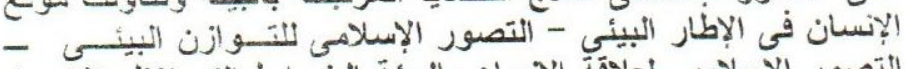

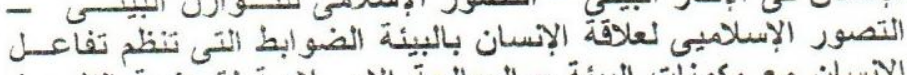

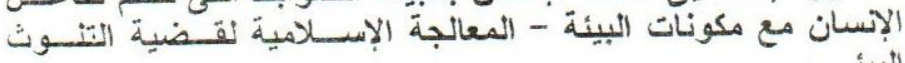




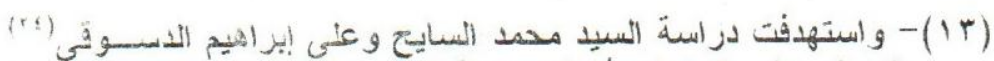

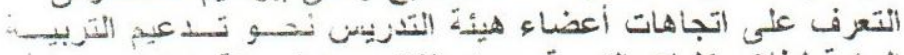

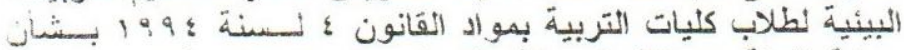

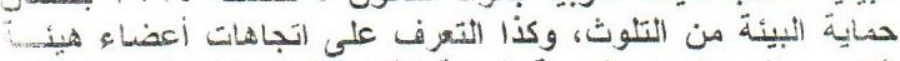

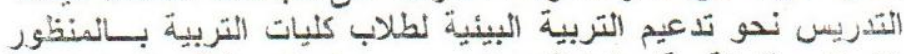

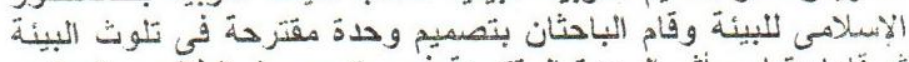

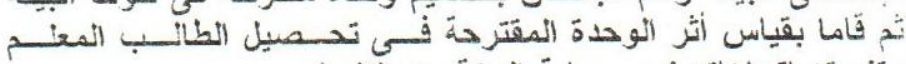

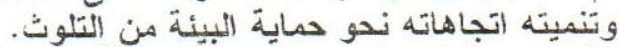

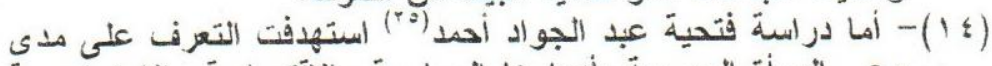

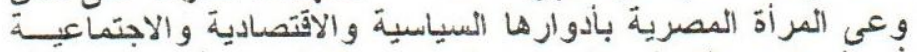

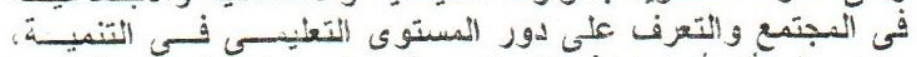

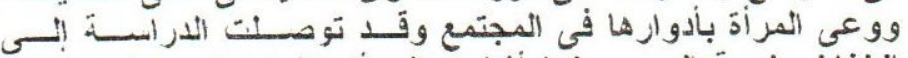

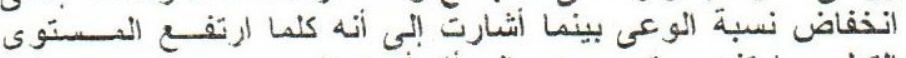

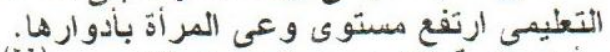

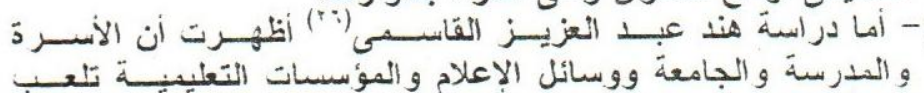

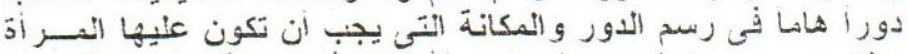

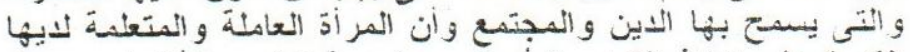

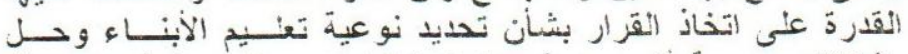

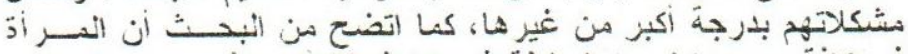

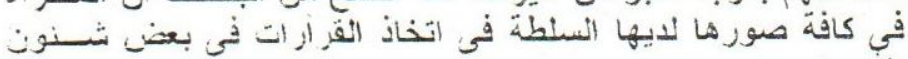

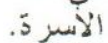

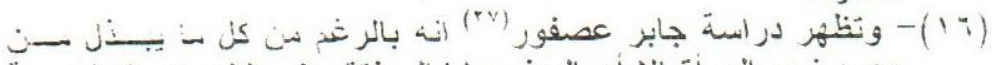

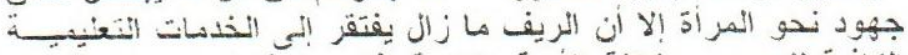

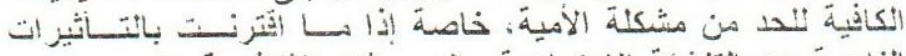

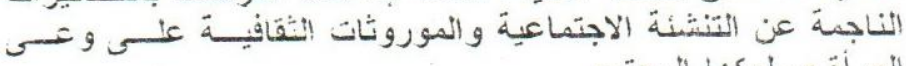

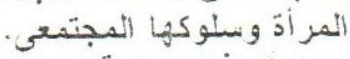
- (IV)

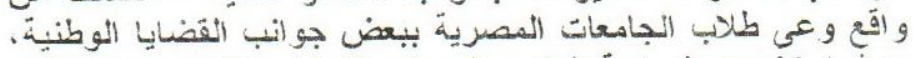

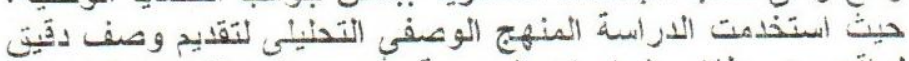

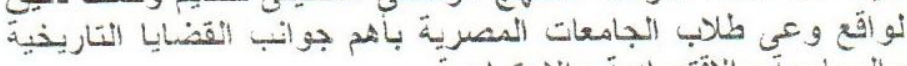

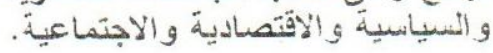

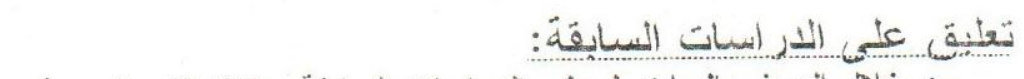

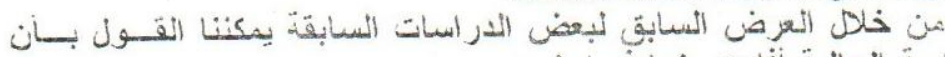

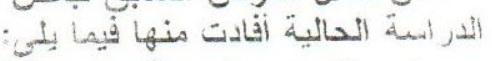

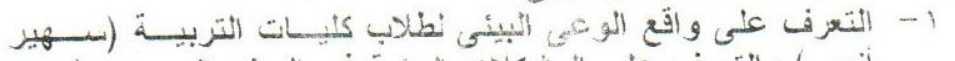

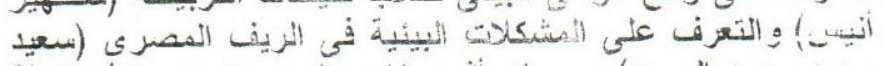

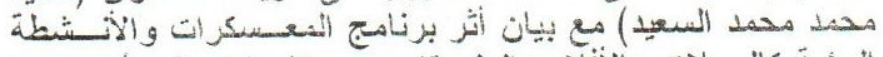

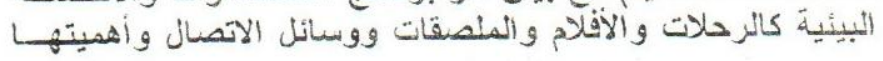


لتنمية الوعى البيئى والاتجاهات البيئية الإيجابية نحو البيئة (عبد

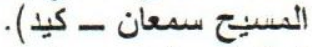
r- الوقوف على دور المؤسسات التربوية في مواجهة مشكلة التوث

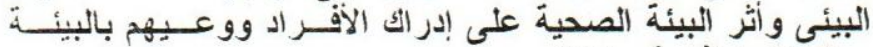
ومشثكلاتها (فادية مغيث).

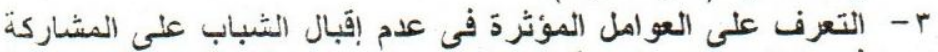

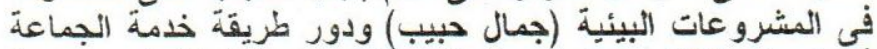

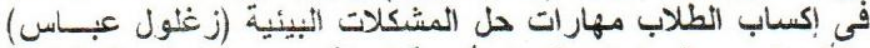

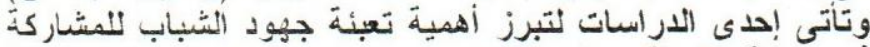

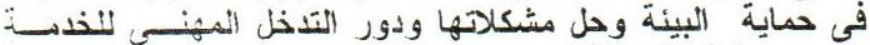

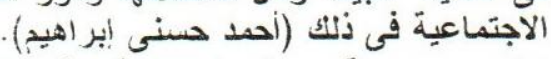

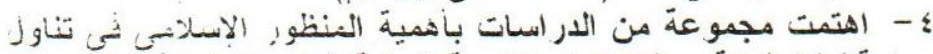

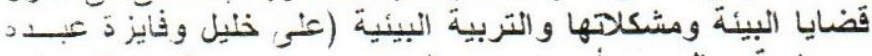

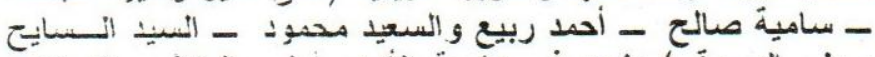

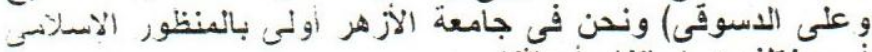
في مختلف دراساتنا و أبحانثنا.

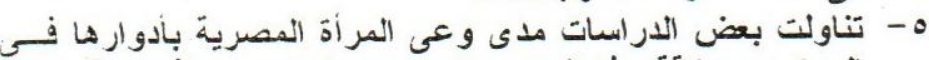

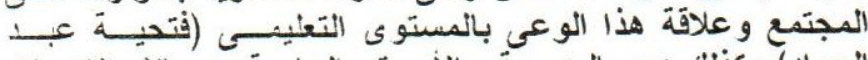

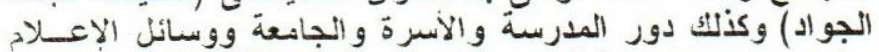

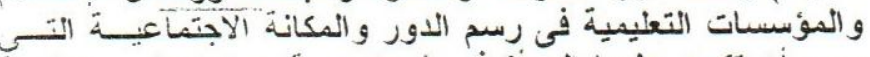

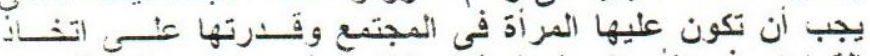

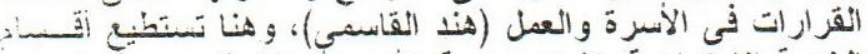

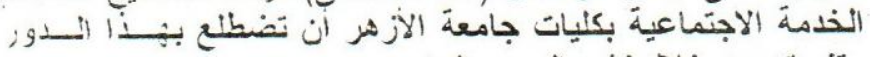

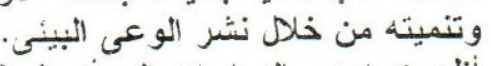

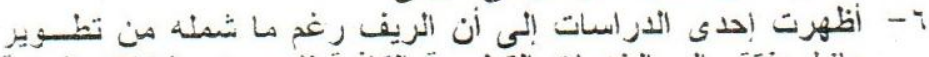

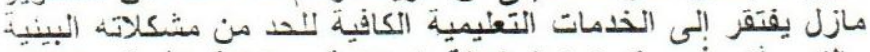

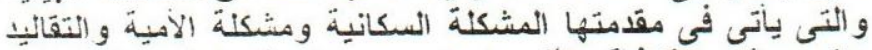

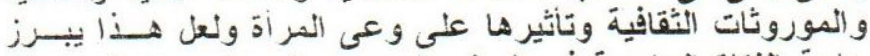

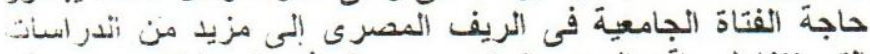

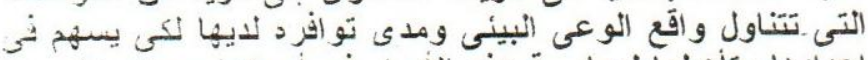

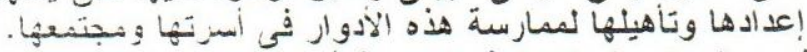

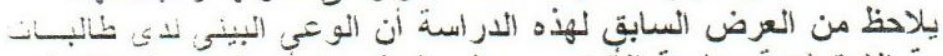

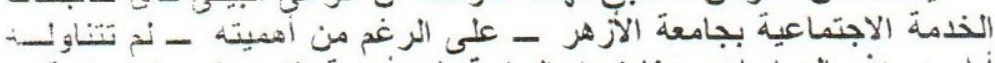

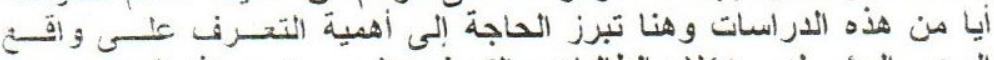

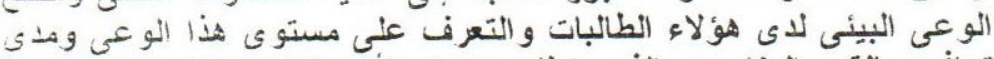

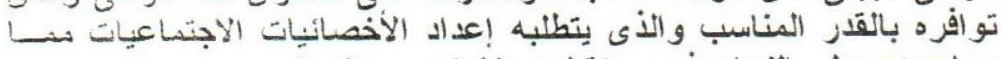

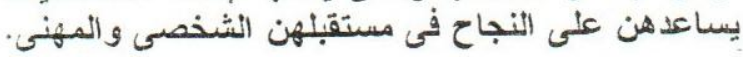

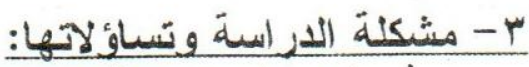

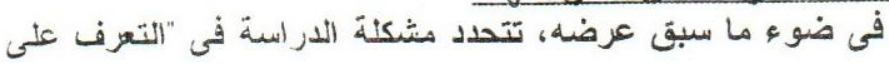




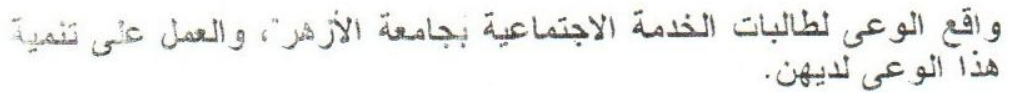

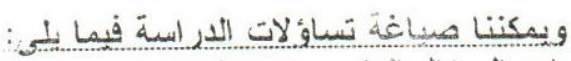

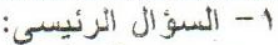

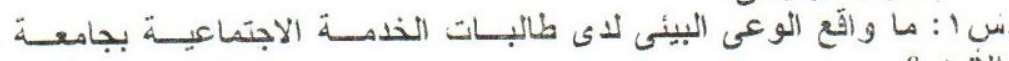

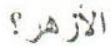

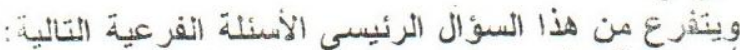

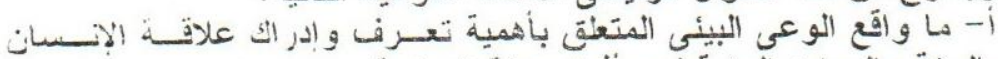

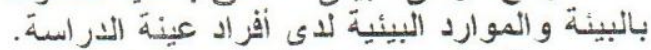

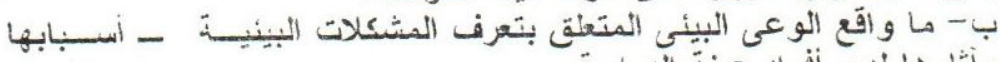

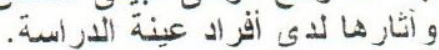

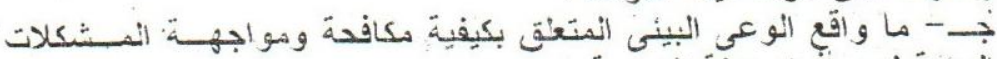

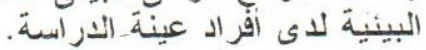

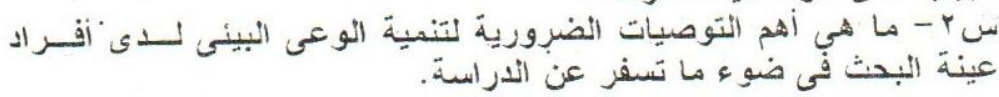

$$
\text { : }
$$

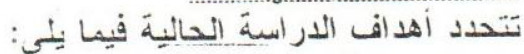

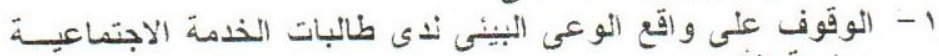

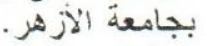

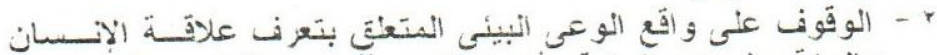

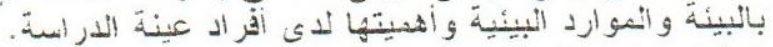

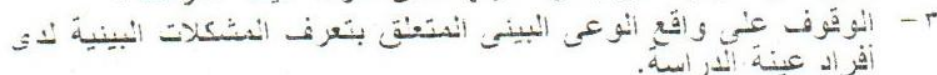

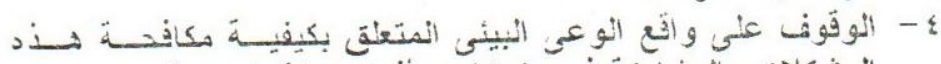

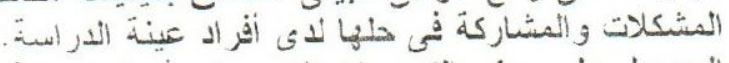

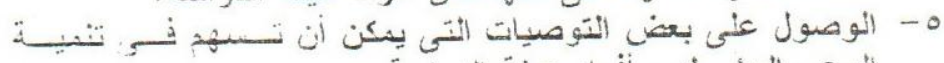

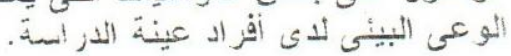

$$
\text { : }
$$

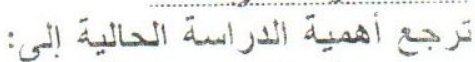

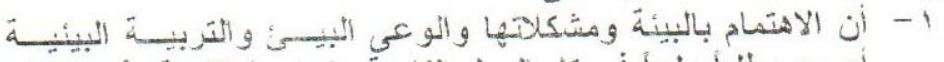

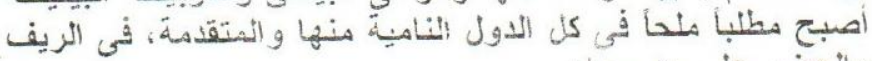

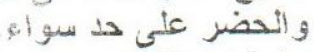

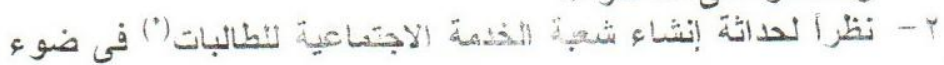

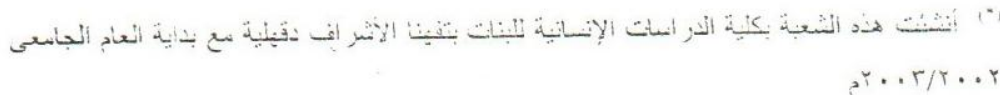




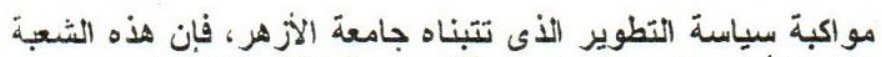

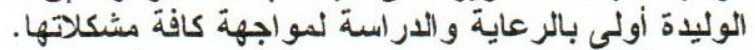

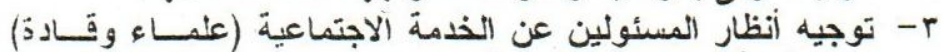

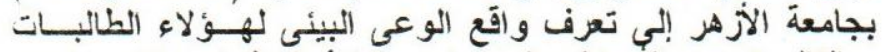

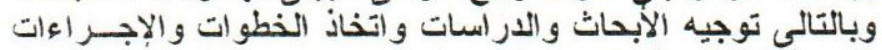

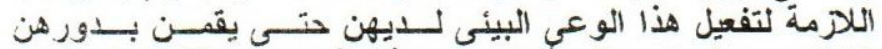

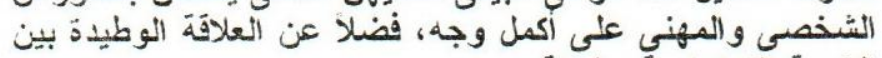
الخدمة الاجتماعيةً و البيئة.

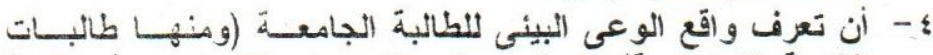

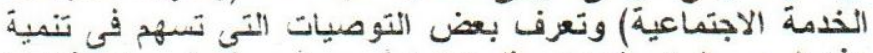

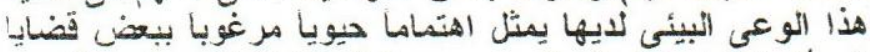

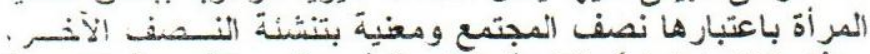

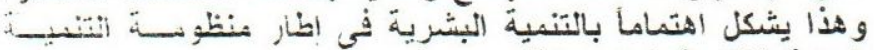

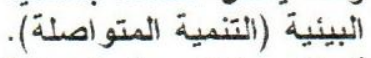

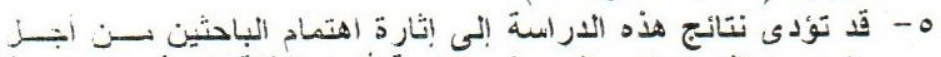

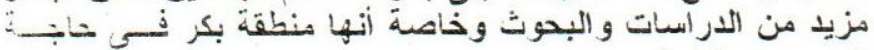

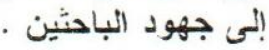

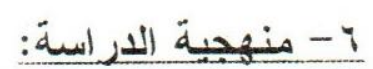

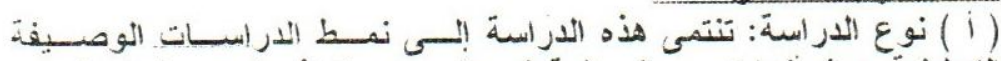

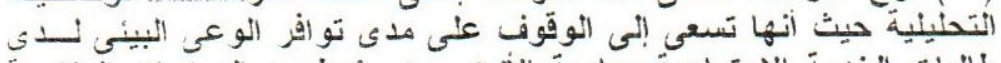

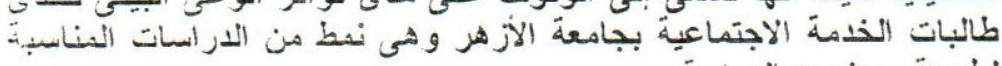

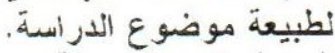

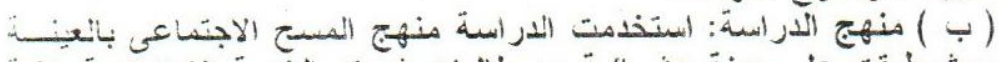

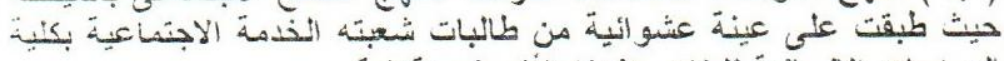

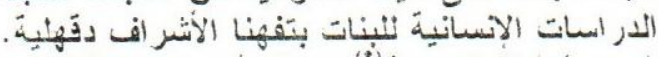

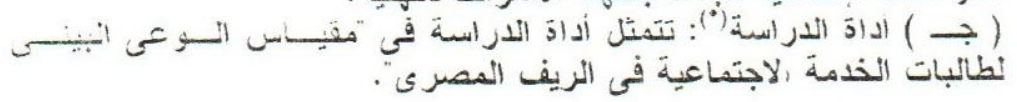
وتضمن إعداد الأدأة النقاط التالية:

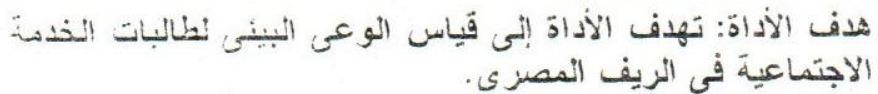

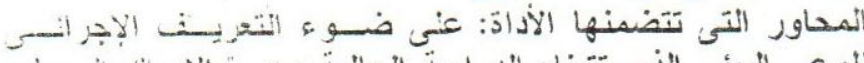

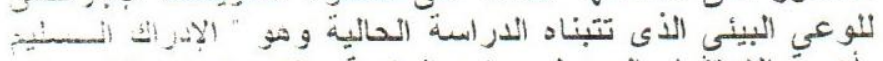

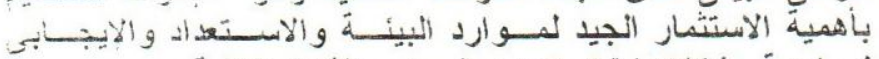
لمواجهة مشكلاتها " تم تحديد المداور الثلاث التمالية: الميدول الأول: الموارد البيئية (الطبيعية و البثرية) و علاقة الإنسان بها. (1) منحق رثم 


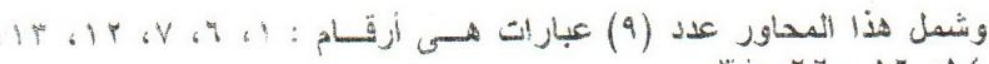

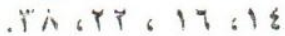

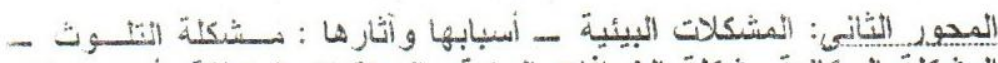

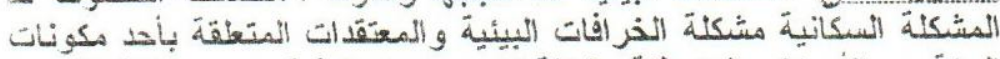

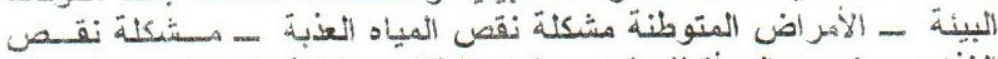

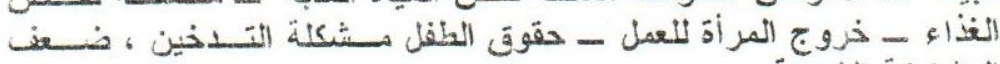
المثنازئة الثنعبية.

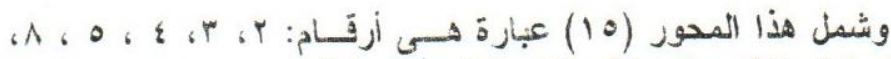

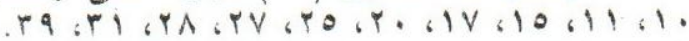

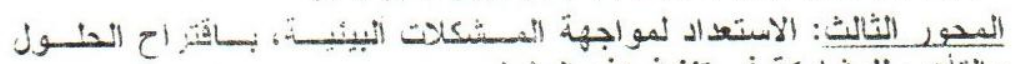

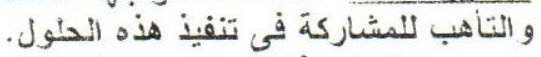

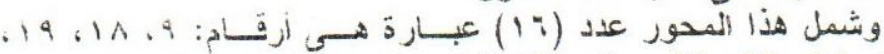

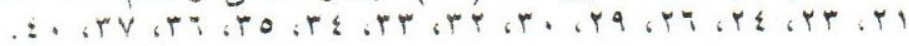

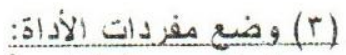

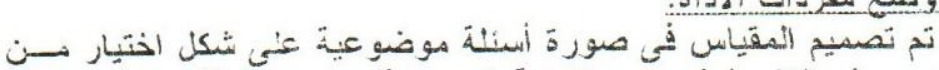

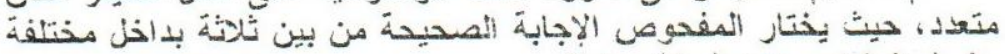

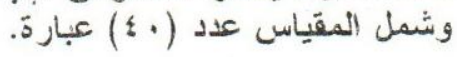

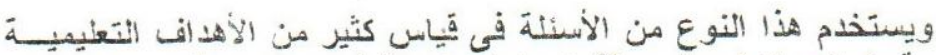

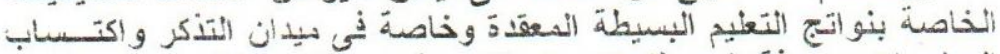

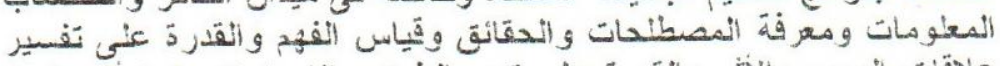

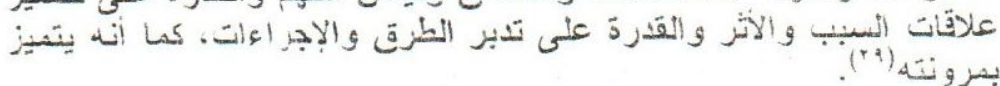

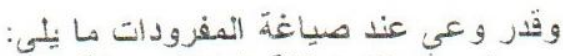

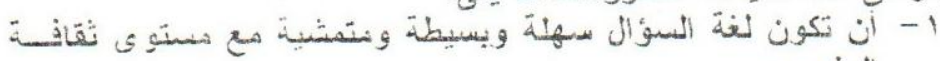

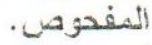

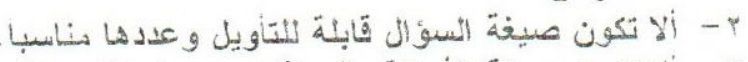

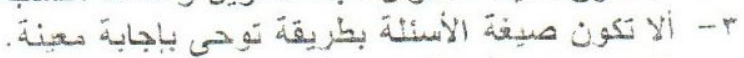

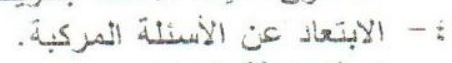

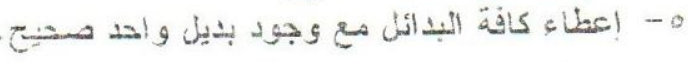

(2)

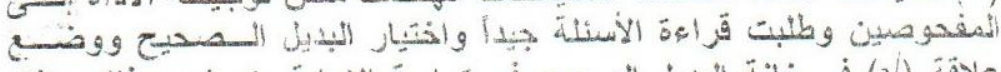

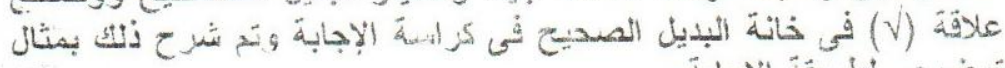
توضيديدي لنطريقة الإجابة.

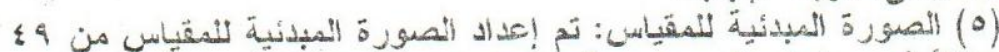

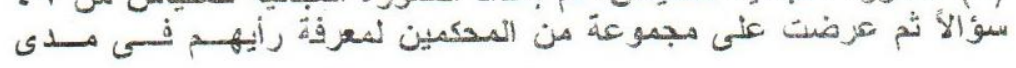


مناسبة الأسئلة نقياس الهُف الأى وضع من أجله و إمكانية تعديل أو إضافة

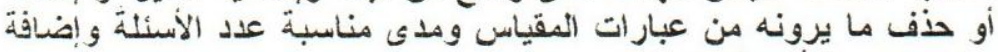
مقترحاتهم بشأن هذا المقياس.

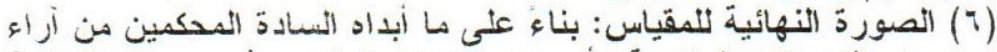

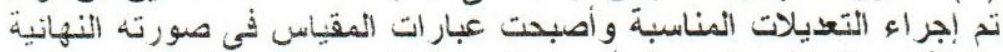

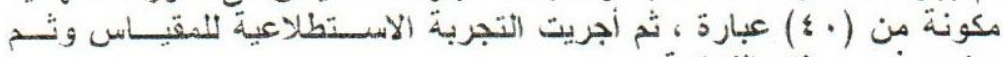
وضعه في صنيغته النهائية.

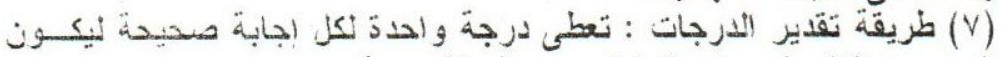

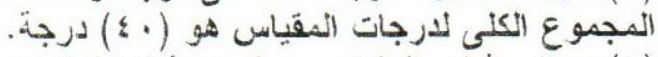

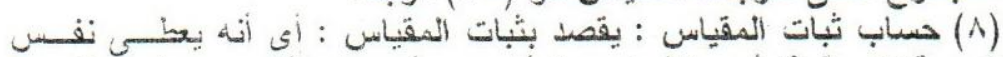

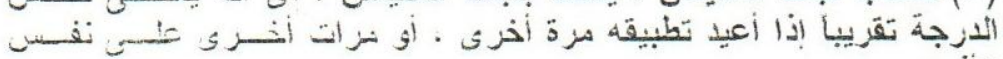

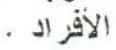

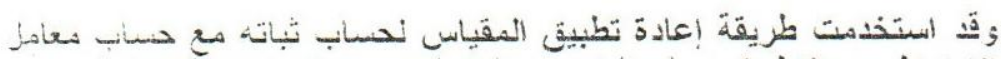

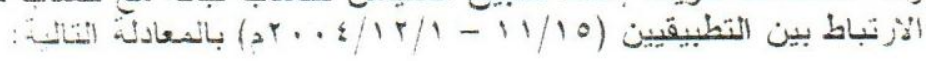

$$
\begin{aligned}
& \text { ن ثجـ س ص - مجـ س × مجـ ص }
\end{aligned}
$$

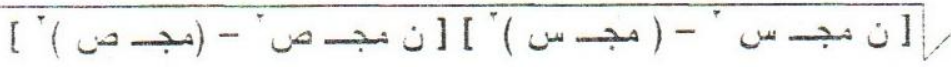

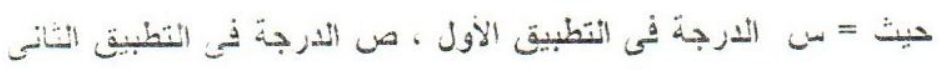

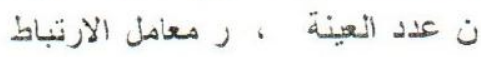

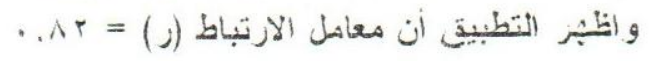

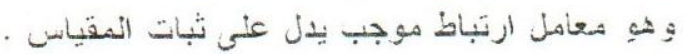

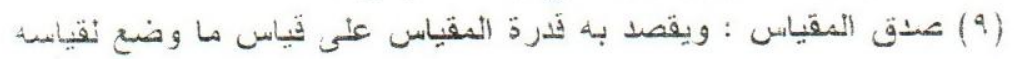

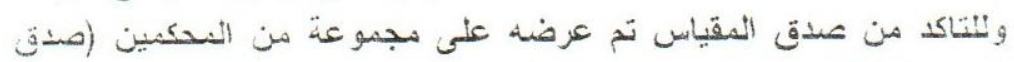

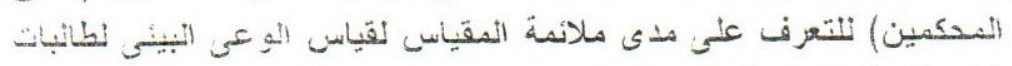

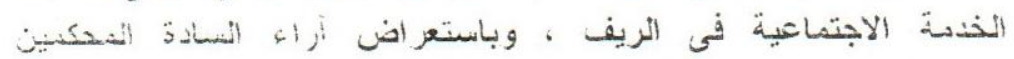

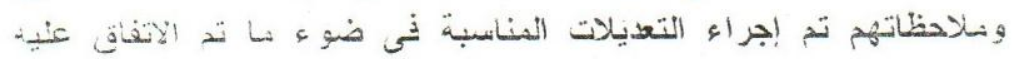

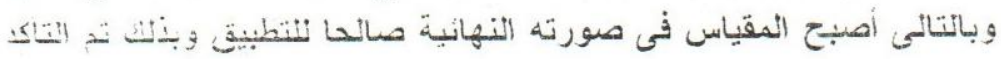

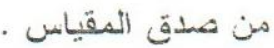

\begin{tabular}{|c|c|c|c|c|}
\hline \multirow{2}{*}{ سنتون الثوعن } & \multicolumn{2}{|c|}{ المنبة المينوية \% } & \multicolumn{2}{|c|}{ عدد الاستنجابات الصـيبحة } \\
\hline & ! & من & ! & هن \\
\hline ضعبف جدا & $\% r$. & صفز \% & 10 & صنز \\
\hline
\end{tabular}


د. دحثل محمد محسود المجوز

\begin{tabular}{|c|c|c|c|c|}
\hline ضعنف & $\% \leq \wedge$ & $\% r r$ & $Y \varepsilon$ & 14 \\
\hline متو سط & $\% \vee$. & $\%$ & ro & ro \\
\hline هرتف & $\% \wedge \wedge$ & $\% \vee r$ & $\varepsilon \leqslant$ & ri \\
\hline سرتفع جذا & $\% \quad, \ldots$ & $\% 9$. & o. & $\leqslant=$ \\
\hline
\end{tabular}

(د) ميالات الثدراسية:

- المجال المكانى : طبقت هذه الاراسة على عينة هن طالبات شعبة الخدمة

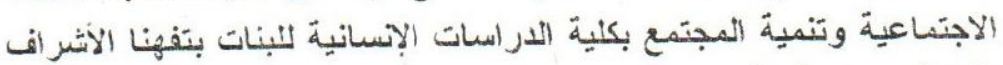

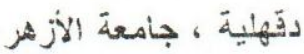

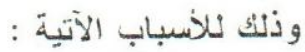

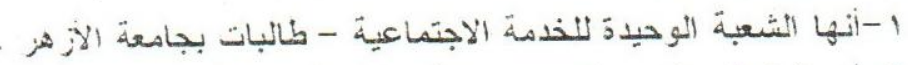

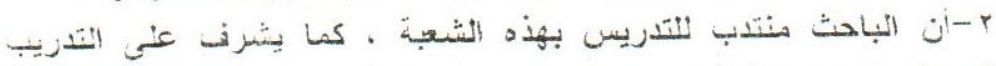

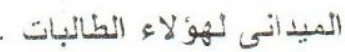

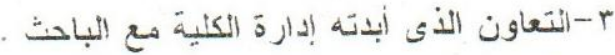

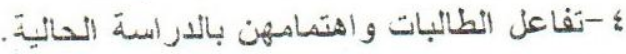

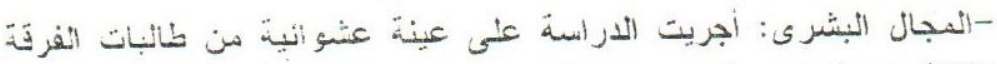

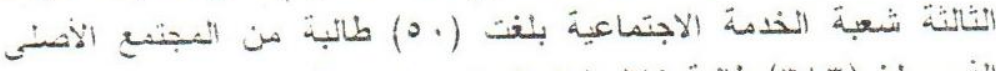

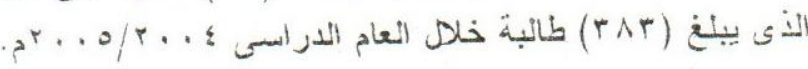
وتم اختيار طالبات الفرقة الثالثة لما يلي:

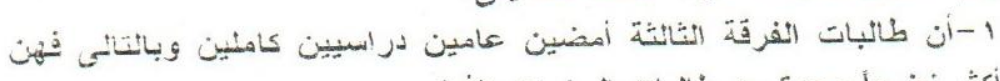

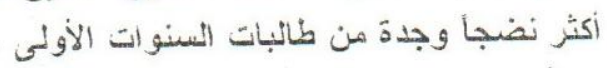

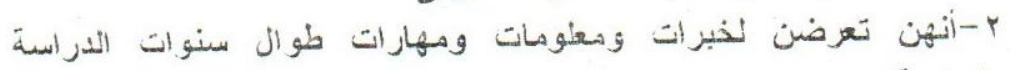

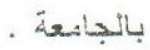

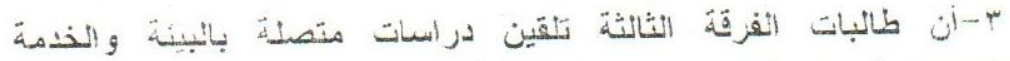

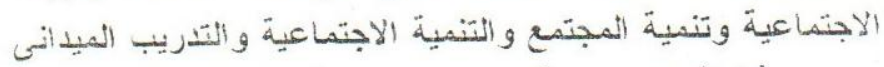

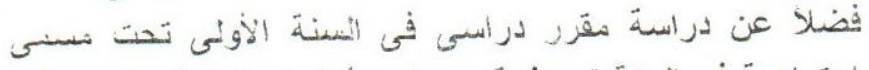

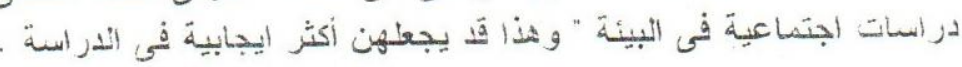

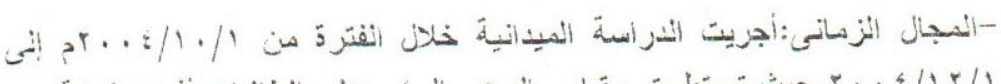

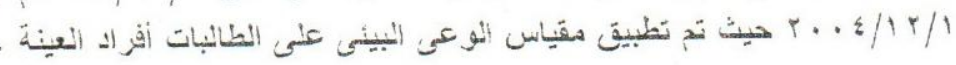




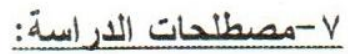 \\ أولاً : مفهوم البيئة}

تتعدد التعريفات التى تناولت البيئة وذلتك نظرا التعدد جوانب التبات التزوايا

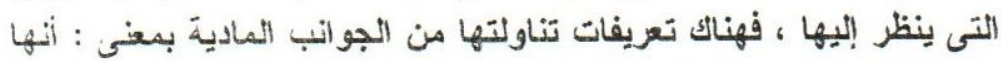

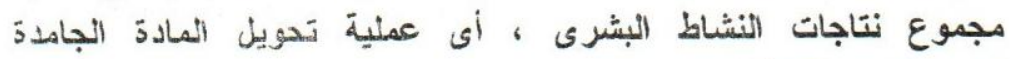
لاستعمالات مختلفة للإنسان .

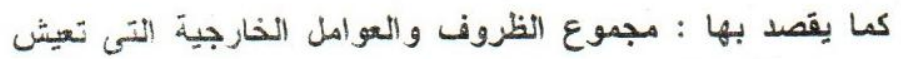

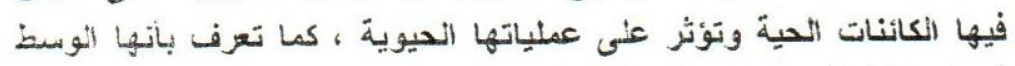

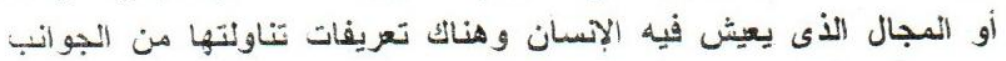

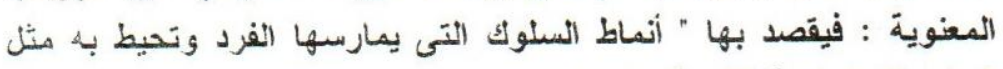

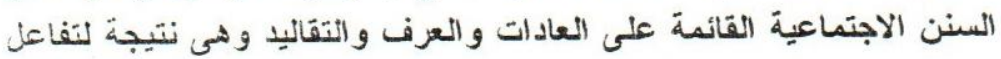

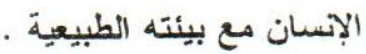

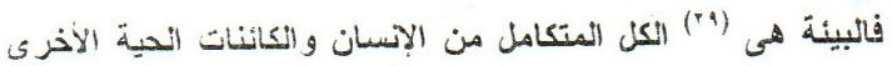

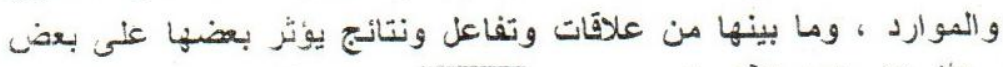

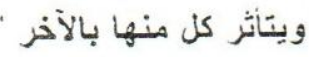

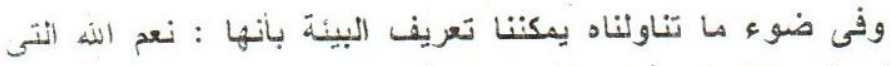

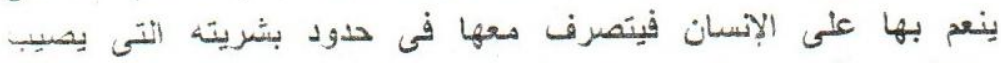

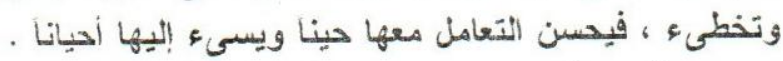

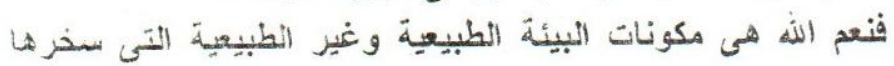

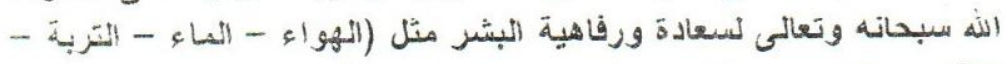

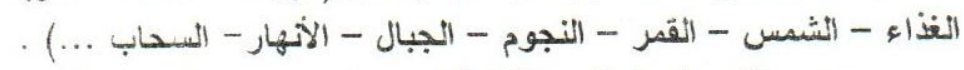

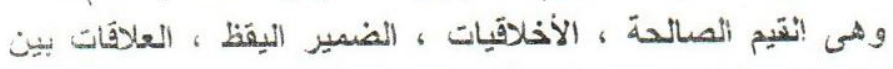

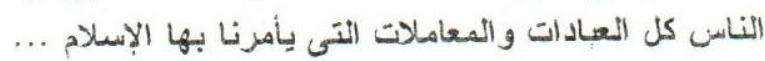

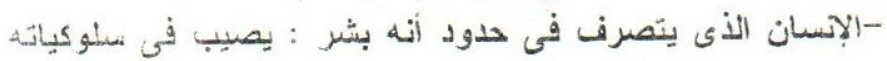

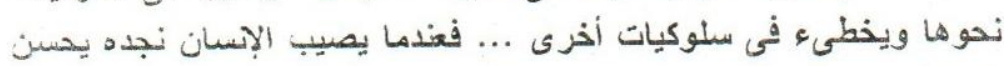

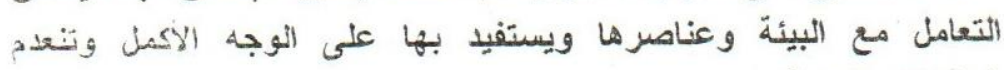

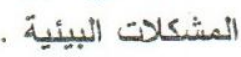

وعندما يخطى : يلوث البيئة ويهلد الموارد ويعهل على أستنز أفها

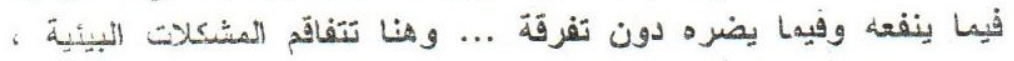

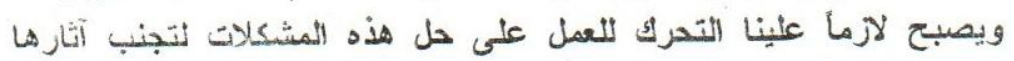


ونتائجها المدمرة على الإنسان وحياته ودستقبل جنسه .

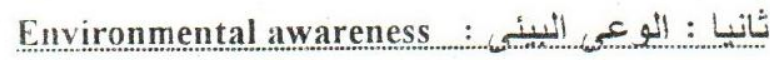

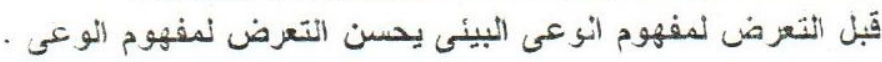

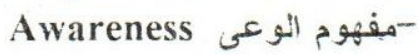
تتعند تعاريف الو عى ويعكس كل نعريف وجهة نظر صاحبه :

- فيرى كراثيول Krathuahl -

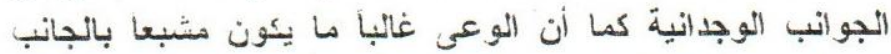

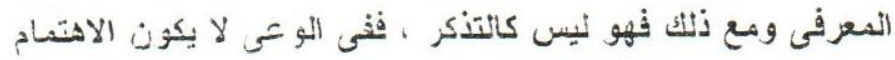

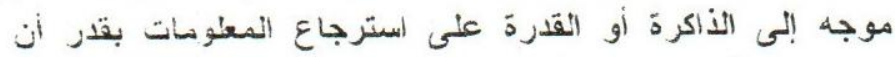

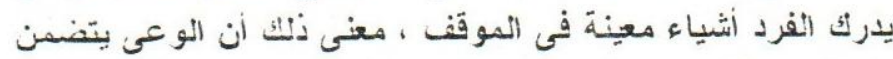

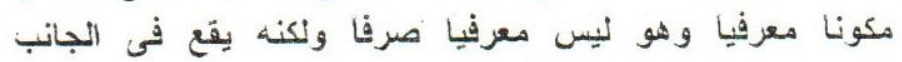

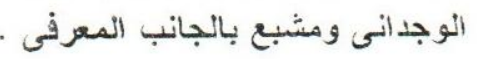

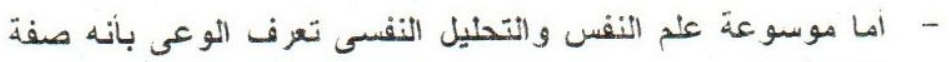

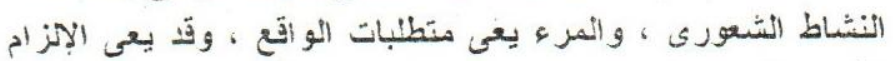

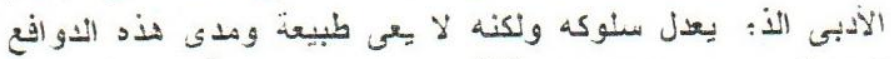

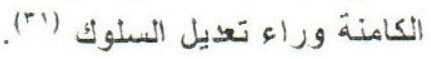

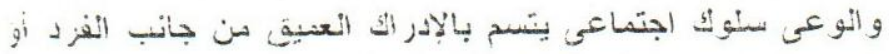

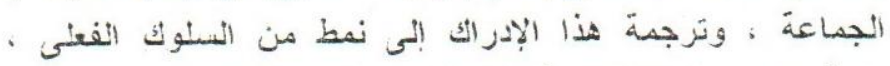

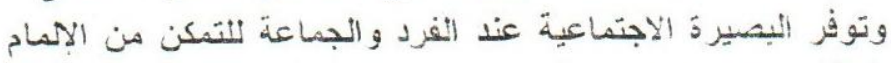

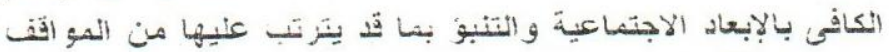
المختلفة (بr)

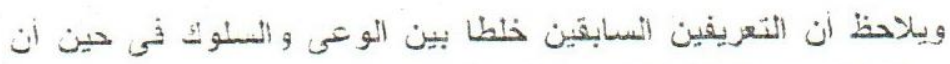

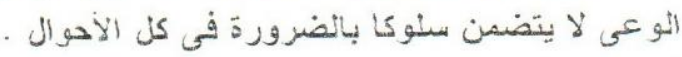

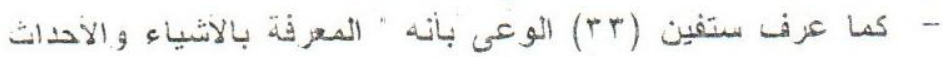

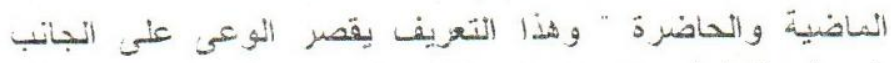

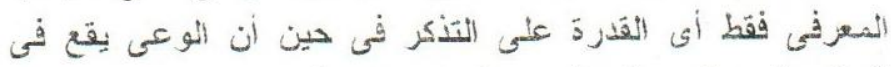

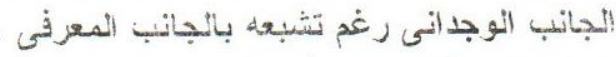

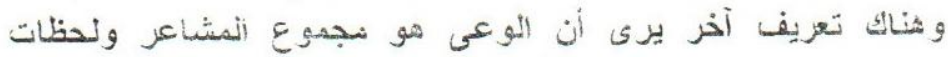

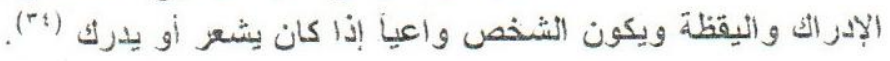


بعد هذا العرض السابق لمفهوم الوعى ننتقل بالحديث عن الموعى البيئى.

• يقول علدى كامل فرج ؛ " " تحتاج البشرية إلى أخلاق اجتماعية

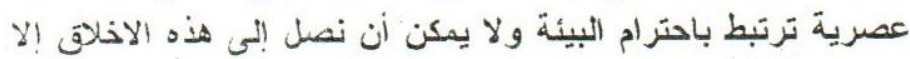

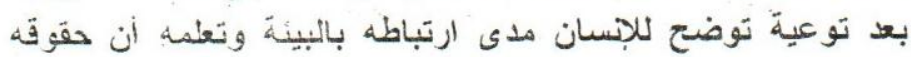

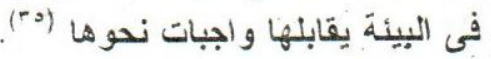

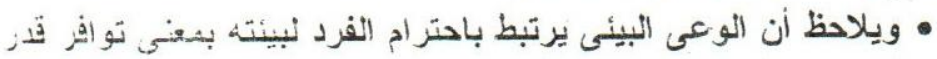

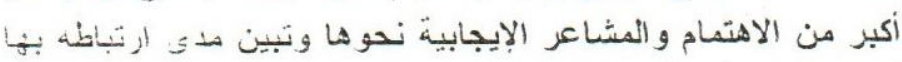

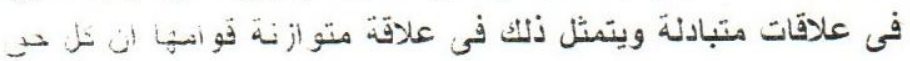

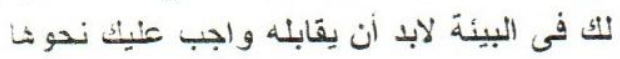

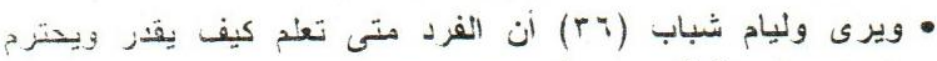

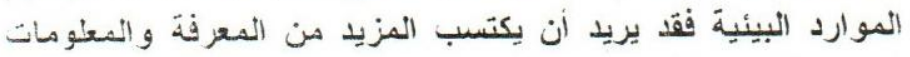

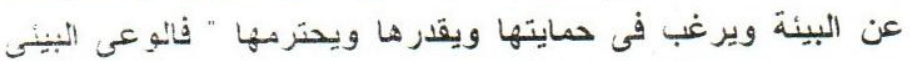

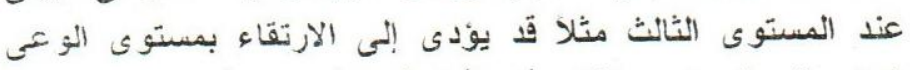

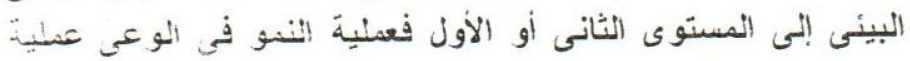

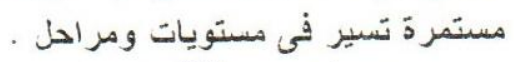

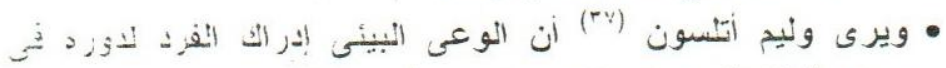

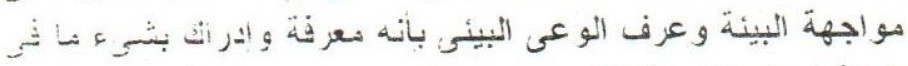

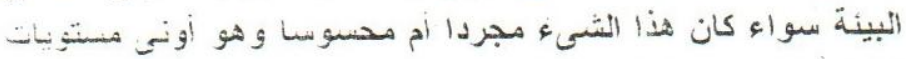

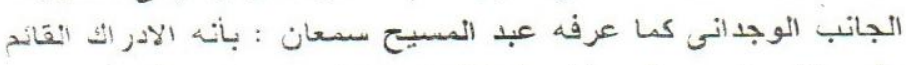

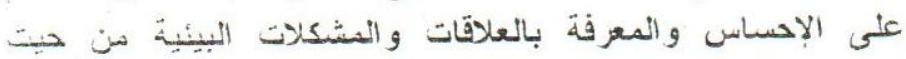

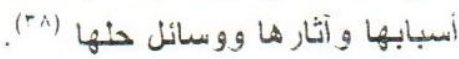

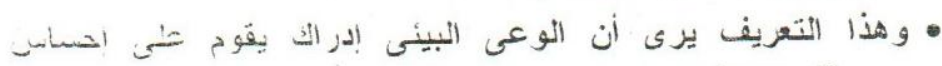

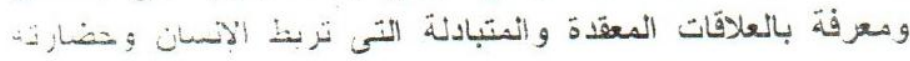

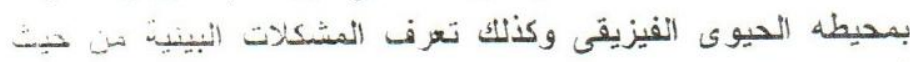

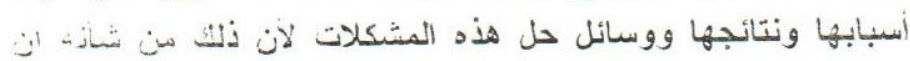

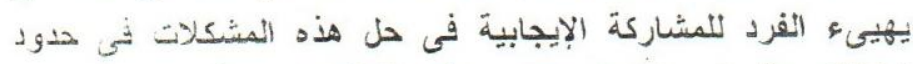

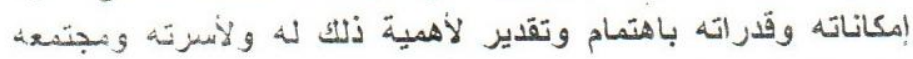

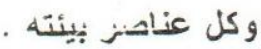

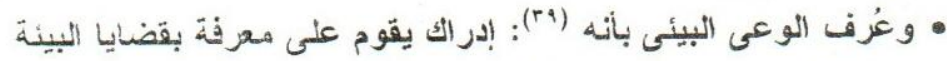

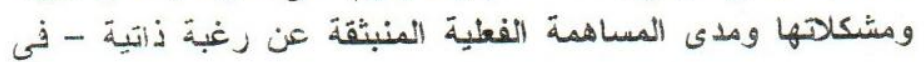


حل تلثك المثكلات و النهوض بالبيئة وحسن استغلال مواردها . ويؤكد هذا التعزيف على أن الوعى البيئى بيعد أساسا لحسن استّنلا.

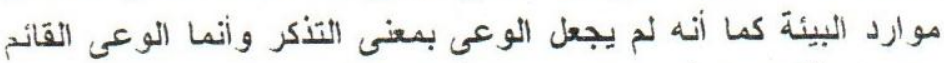
على معرفة تحمل فى كونها جانبا وجدانيا يدفع إلى الممار سة الإيجابين ، كما حدد مصادر كثيرة للوعى البيئحى سواء مؤسنسات التربية النظامية أو غير النظامية هـية

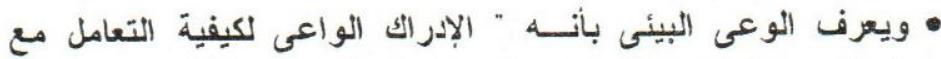
البيئة بوصفها الغلاف المحيط بالإنسان فهو يحافظ عليها لإدراكه الأنه

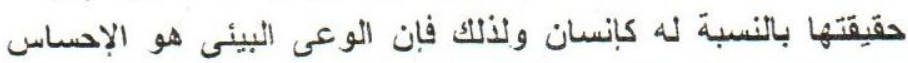

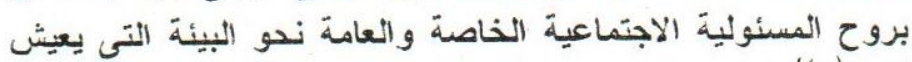
فئان (•)

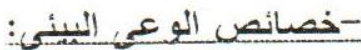

باستعز اض وهناقثة التعاريف السابق ذكرنها للو عى البيني يمكنتا بلورة

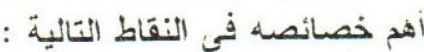

- أن تكوين الؤى البينى وتنميته لا يقتصر على التربية النظنمية

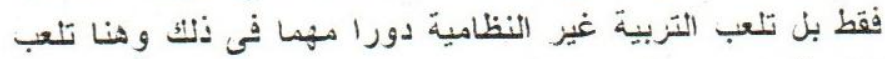

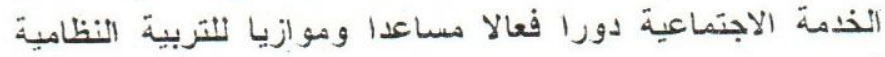

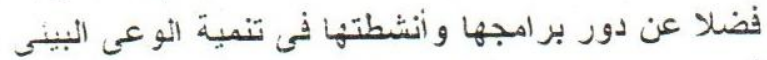

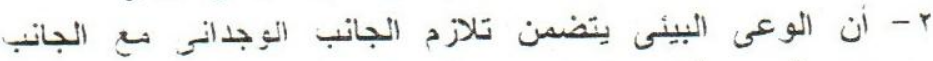

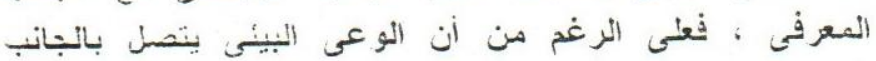

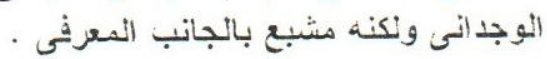
r- أن تنمية الوعى البيئى ليست ثابتة ونكنها ارتقائية فقتليل هن

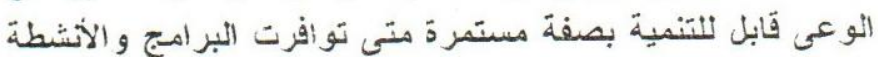

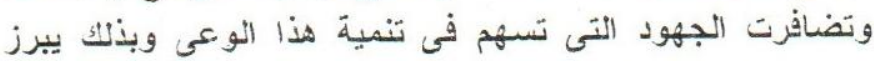
اللاور الفاعل للاسرة والمدرسة والجامعة ووسدئئ الإعلام

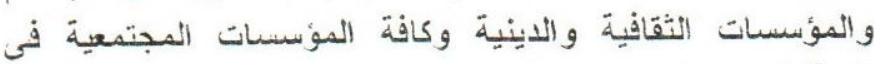
تنتمية الثوعى النبئئى.

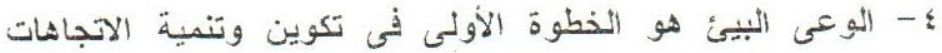

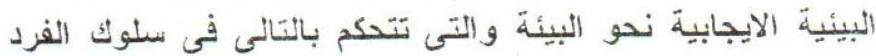

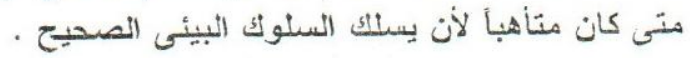


ه- للوعى البيئ وظيفة تنبئوية عما يمكن أن يصدر هن سنوك الفرد تجاه البيئة مستقبلا.

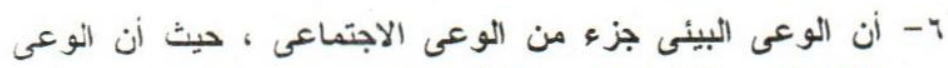

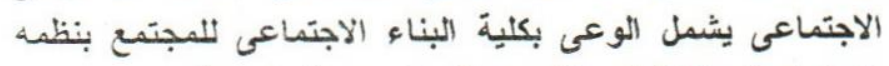

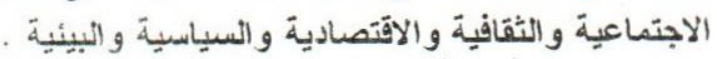
-V

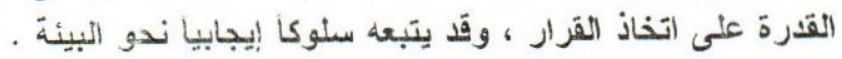

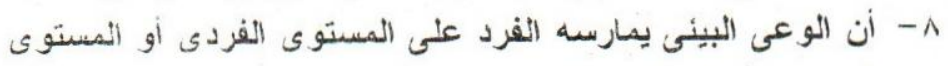

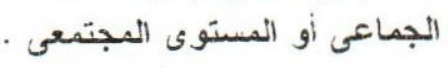

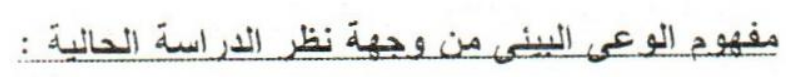

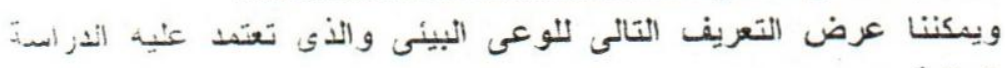

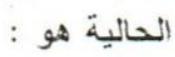

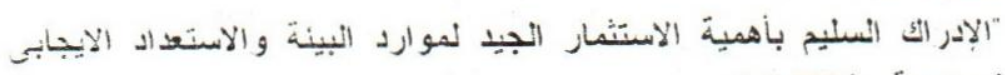
لمو اجهة مشكلاتها ".

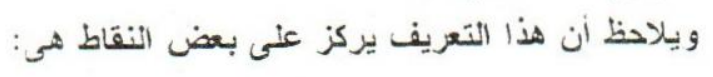

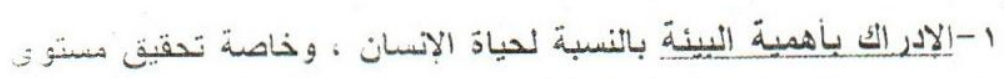

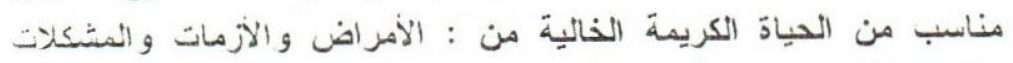

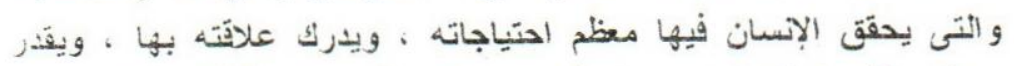

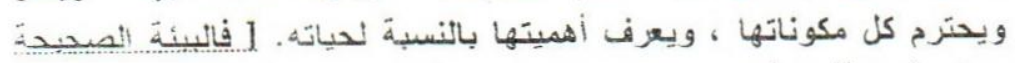

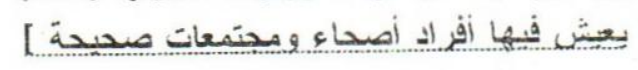

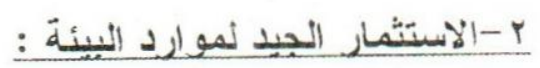

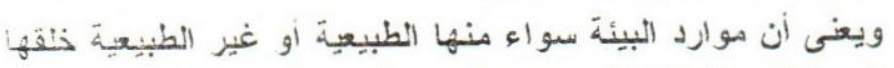

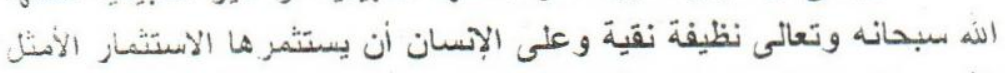

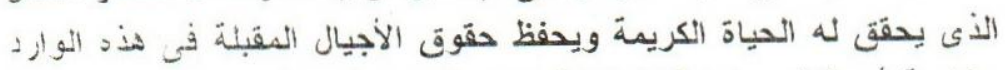

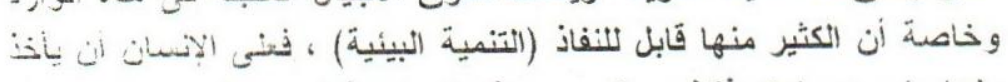

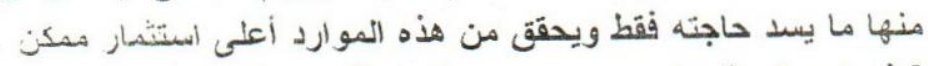

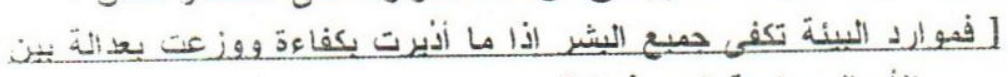

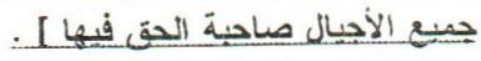




\section{با-بينيكات اليبينة}

بمغنى تعرف هذه المشكلات التَى تقلل من الاستثمار الر اشتد للموردي

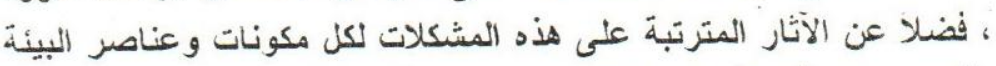

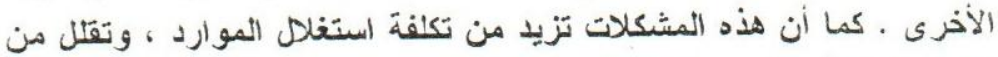

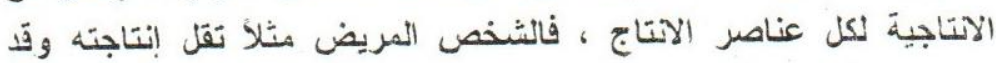

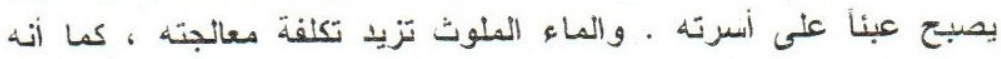

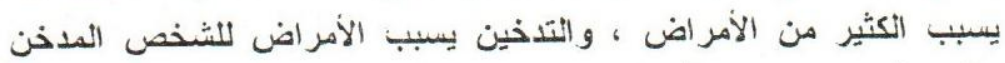

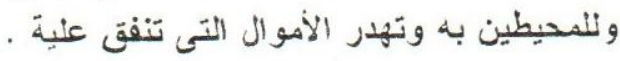

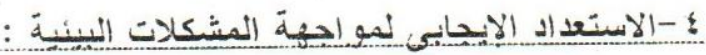

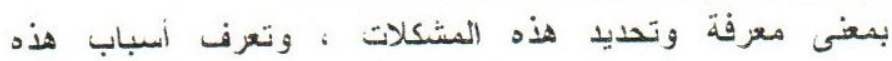

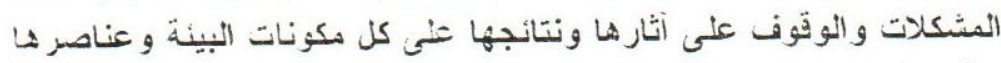

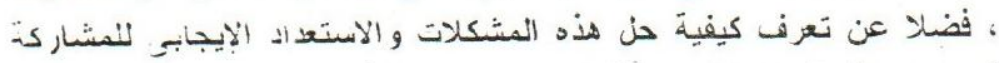

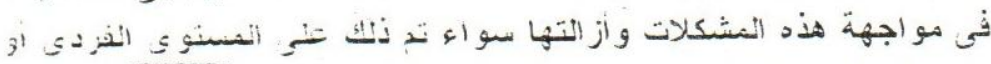

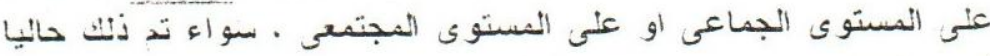
او سستقبلا .

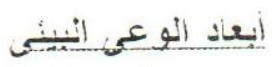

في ضوء التعريف الأى تتبناد الدراسة الحانية يمكن تحديد الأبعاد

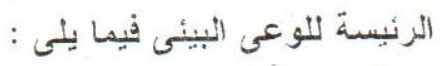

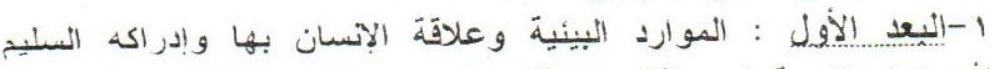

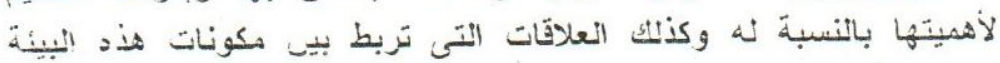

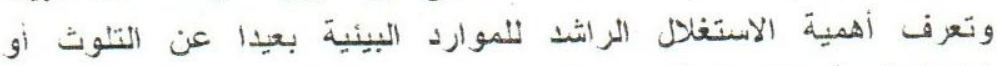

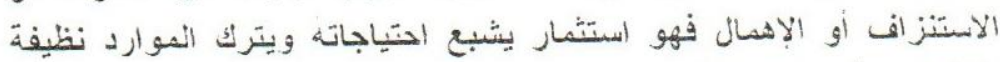
نقيةً إلى الأجيال النقبلة.

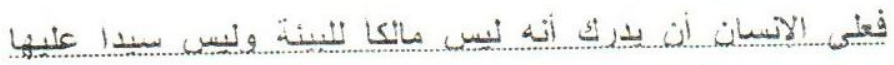

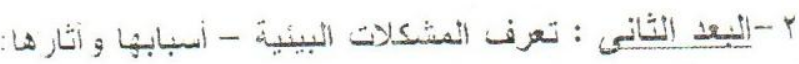

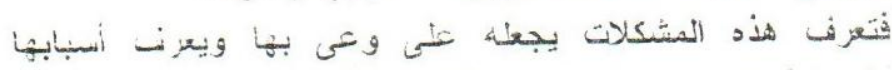

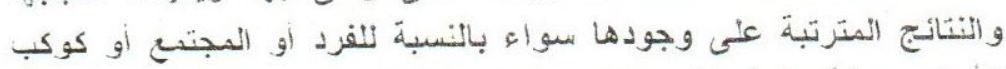

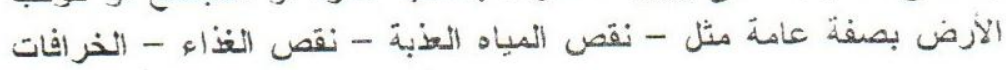


المرتبطة بالبيئة - خروج المر أذ للعمل - حقوق الطفولة - مشكنة التدخين

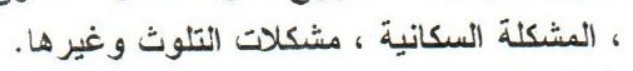

ب-اليبع الثالث : الاستعداد الإيجابى لمواجهة المشكلات

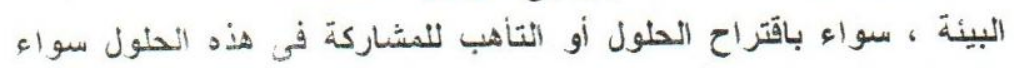

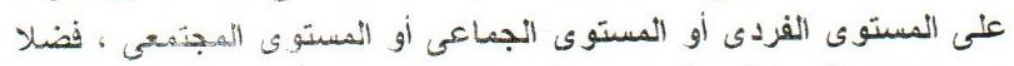

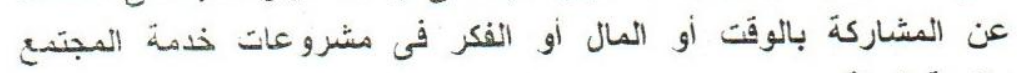
وتنمية البيئة .

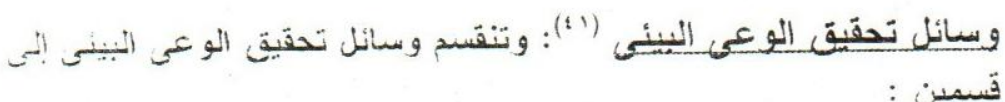

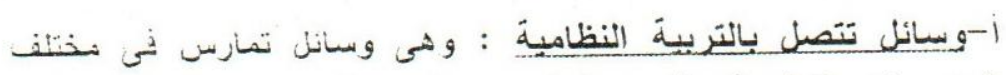

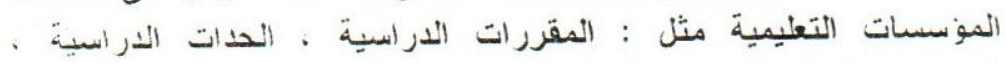

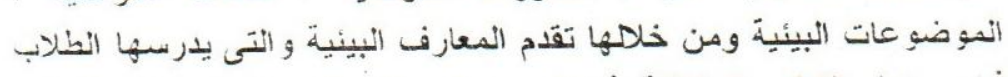

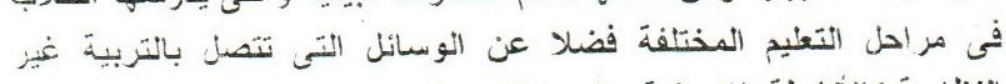

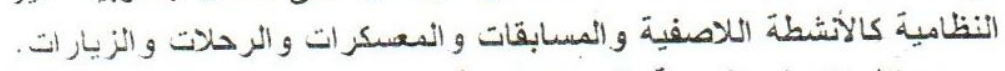

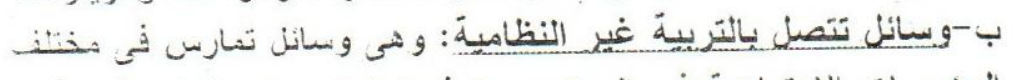

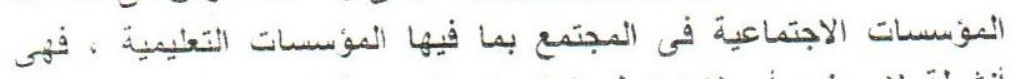

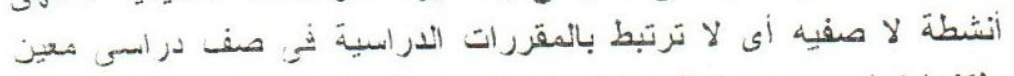

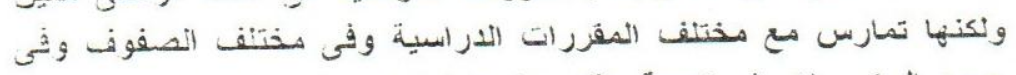

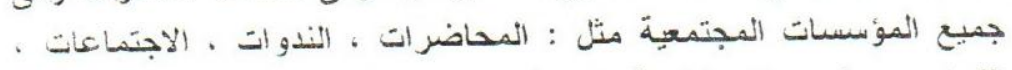

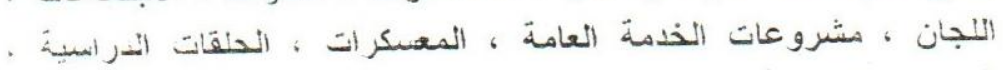

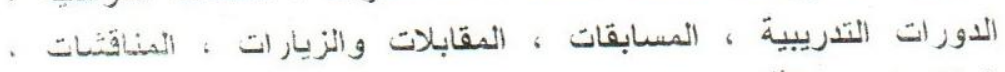

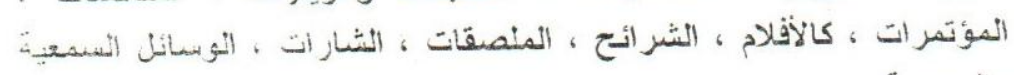
و البصرية.

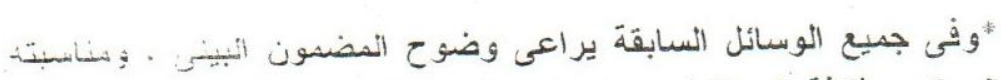

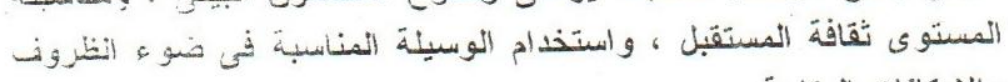

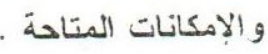

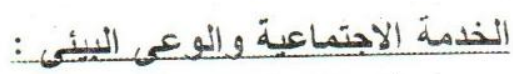

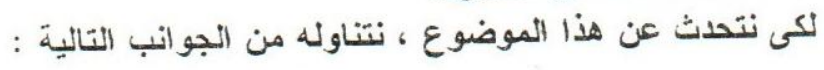




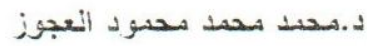

أ-انذمة الاجتماعية والوعى البيئي هن خلال بعض اللاز اسات الميدانية

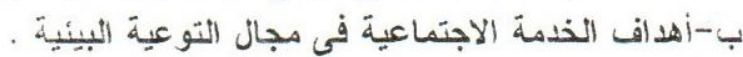

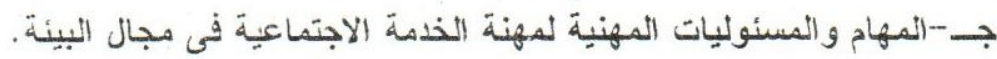

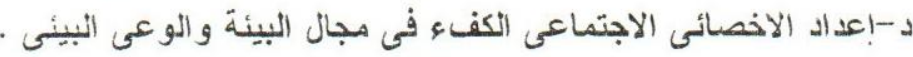

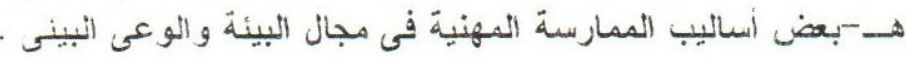
و الآن نتناول هذه الجوانب بشييء من التفصيل .

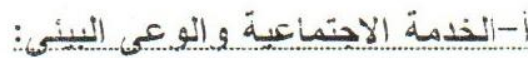

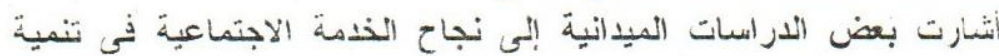
الوعى البيئى فى بعض المجالات منها هذّلا:

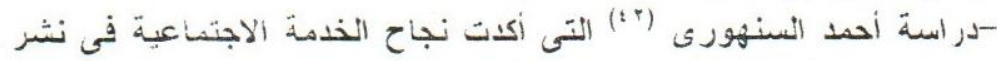

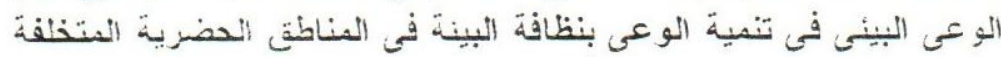

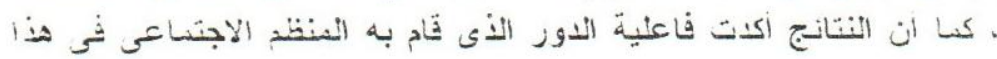
-وانشارت دراسة ملاك الرشيدث ونصيف فهنى (-") إلى أن الخدمة

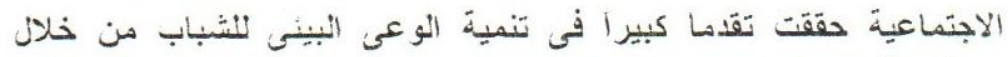

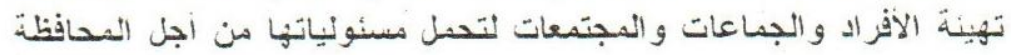
عنى النبيئة . -و أنشارت دزاسة جمال حبيبة ، هريم إبراهيخ (:") إنى نجاح الأخصائى

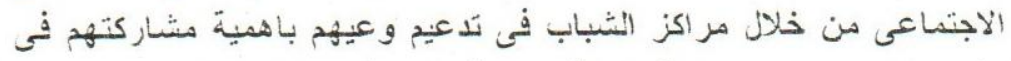

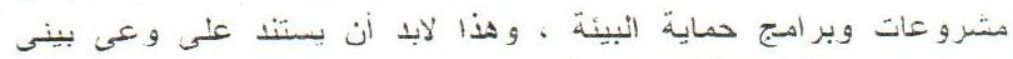

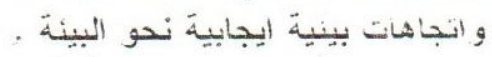

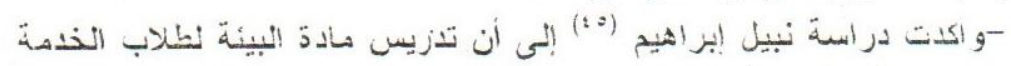

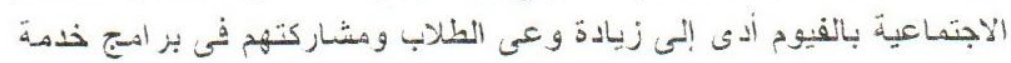

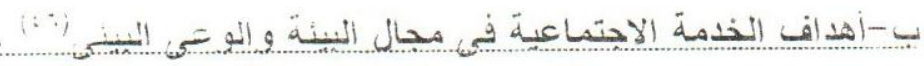

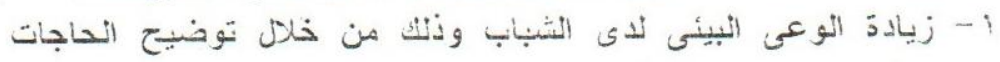

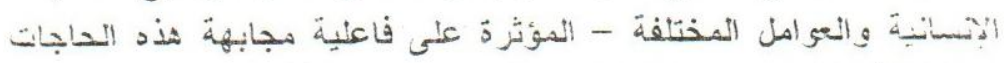
داخل الإطار البيئي دون الإخلال بانتظاهـ وتكامله .

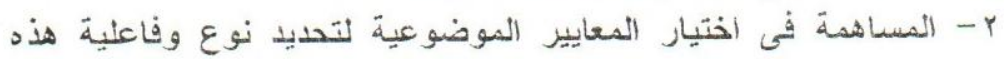




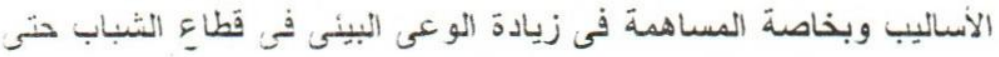

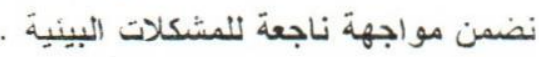

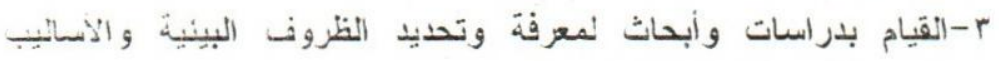

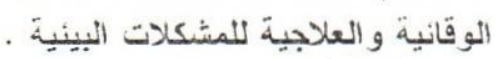

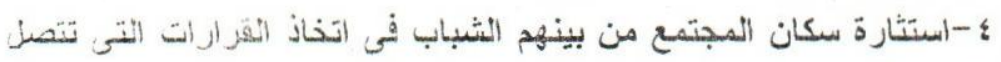

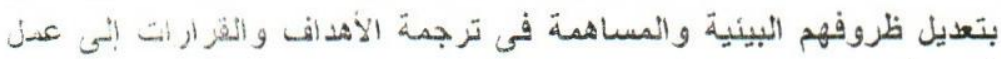

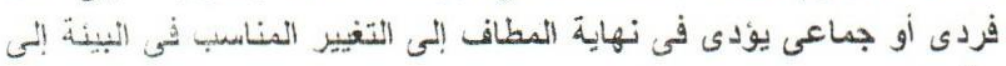
الأفضل .

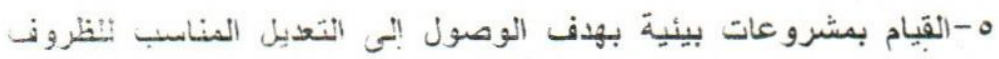

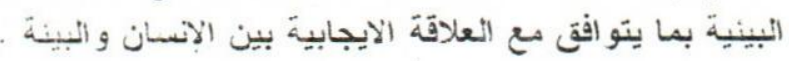

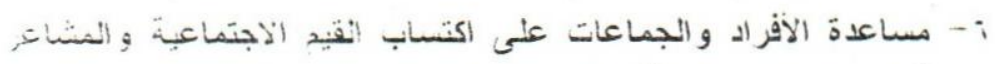

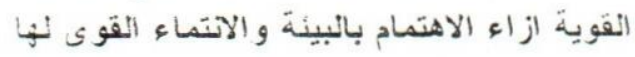

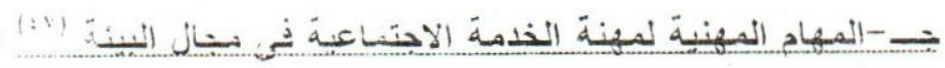

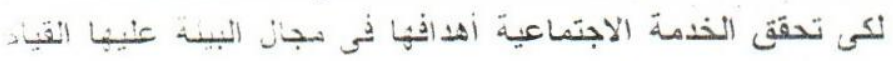

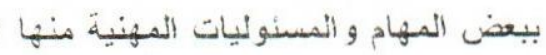

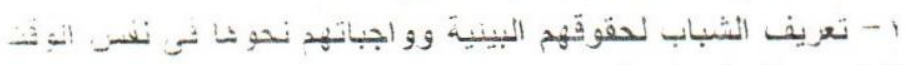

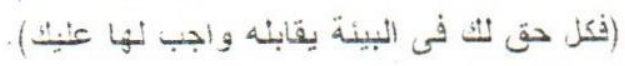

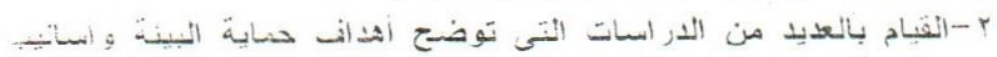
حمايَتها.

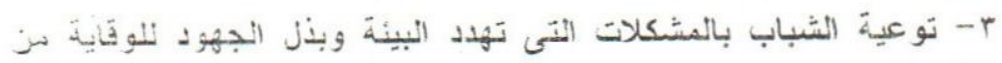

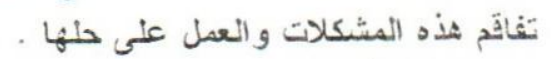

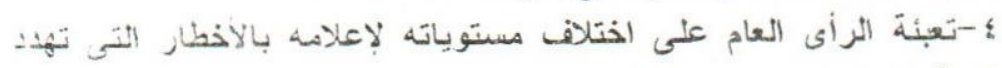

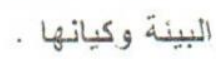

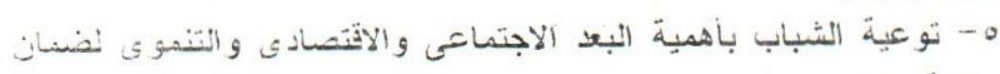

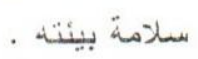

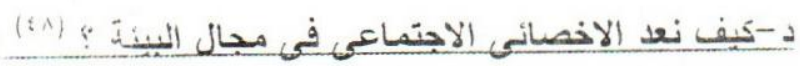

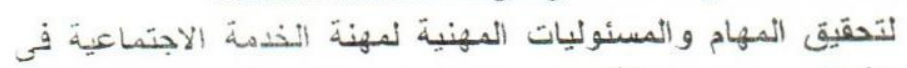

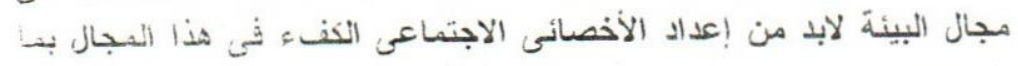


ا - الإلمام ببعض المعارف الأساسية المتعلقة بالمعارف و الحقانق البيئية. r - الإمام بطبيعة المشكلات البيئية ومدى ارتباطها بالجو انب الاجنية الاجنماعية.

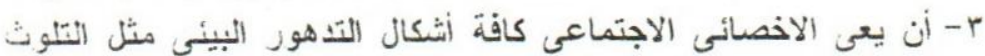

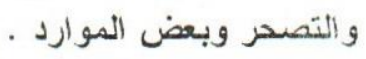

؛ - مساعدة الاخصائى الاجتماعى لكى يفكر فى النسبل التى يتوصل بنها لحل هذه المشكلات.

0- الإمام بالنظريات التى تفسر وتحلل المثكلات انبيئية وكيفية علاجها.

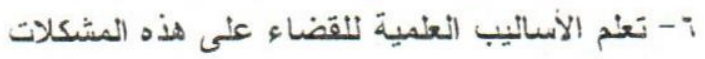

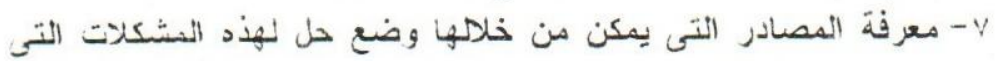
تو اجه البيئة.

- - الاتصال بالأجهزة المعنية لوضع حلول فورية لمواجهة الاخطار التح تلدمر البينية.

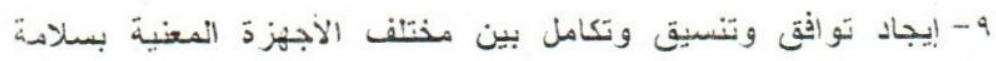
المبيئة.

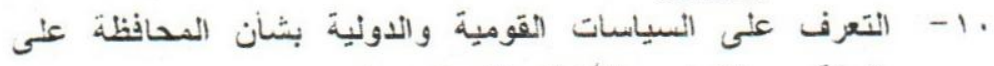

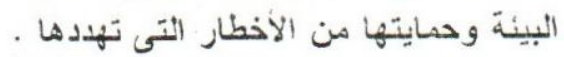

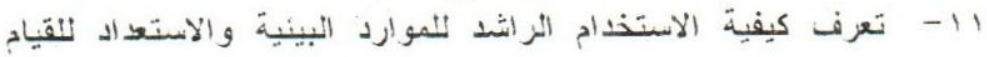

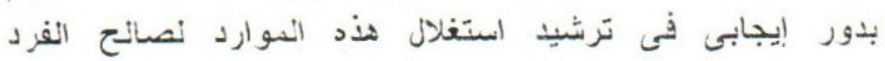

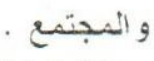

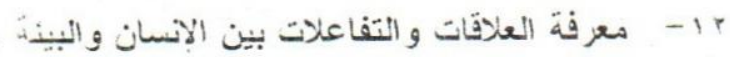

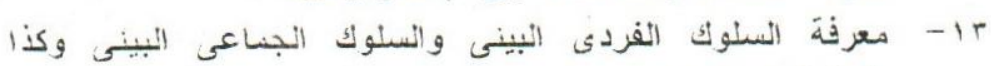

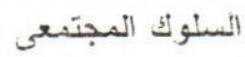

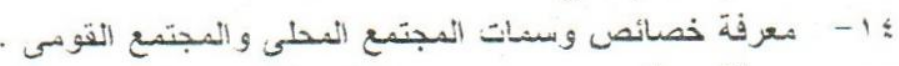

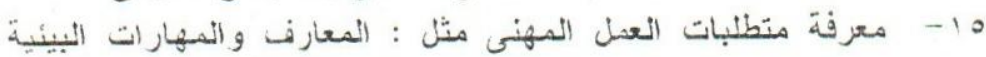

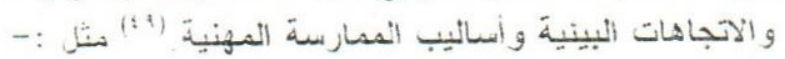

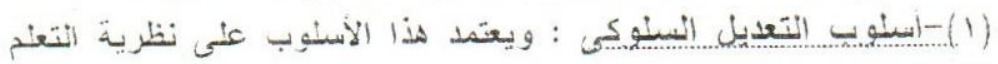

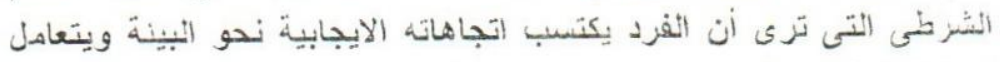

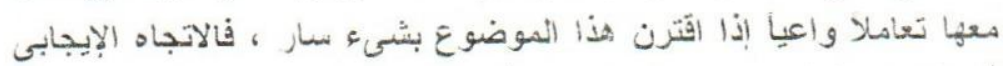

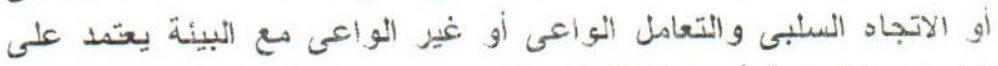

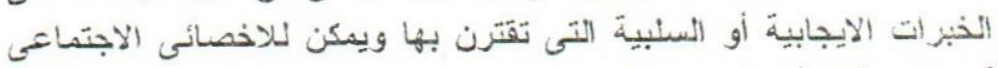

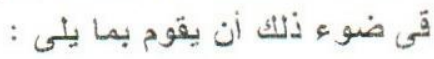


1- استخدام طرق التدعيم الإيجابى فى تحسين البيئة وذللك بتقديم الحو افز

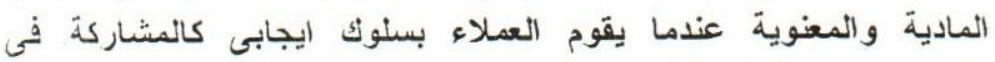

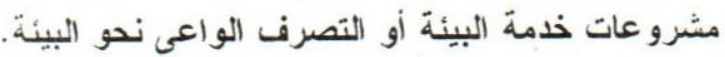

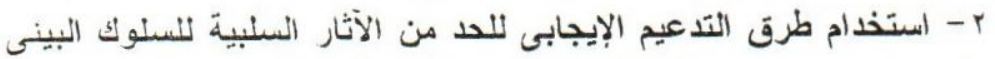

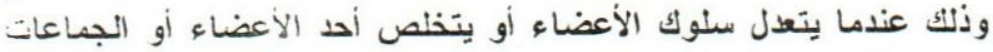

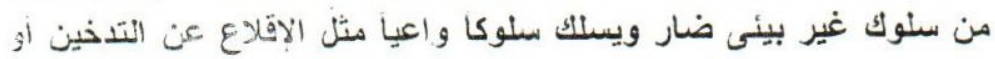

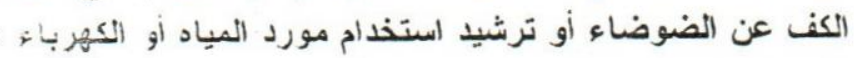

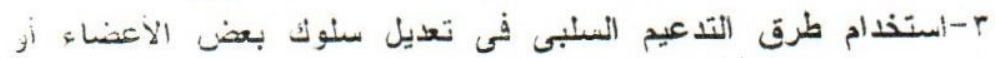

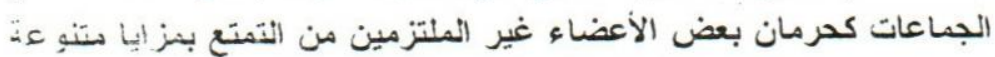

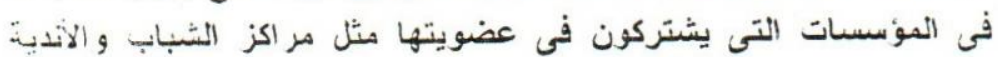

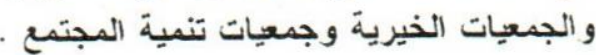

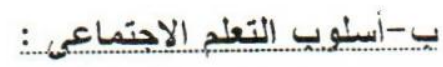

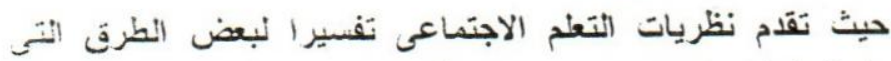

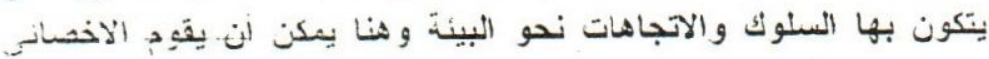

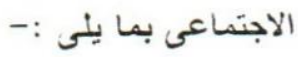

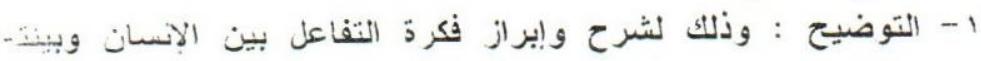

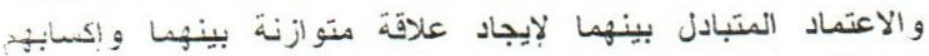

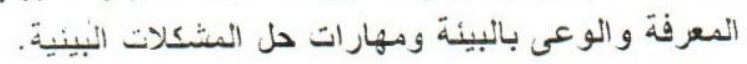

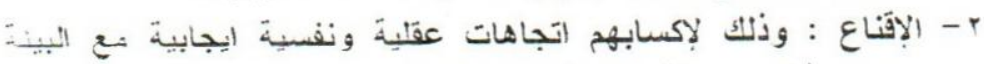

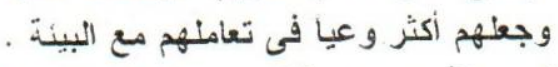

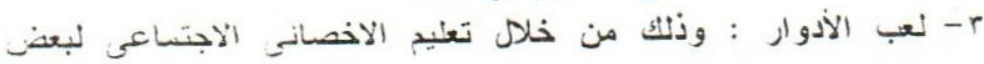

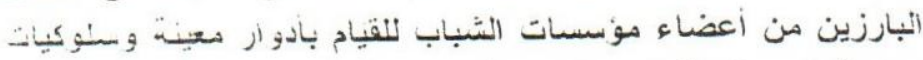

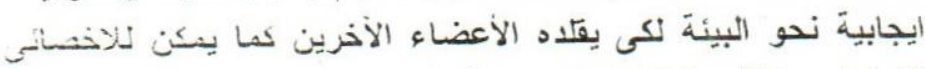

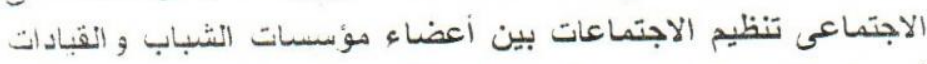

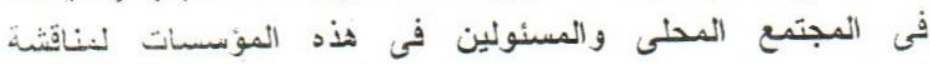

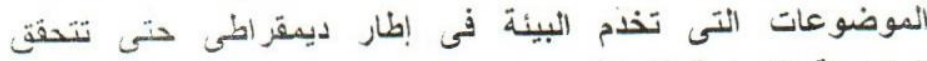

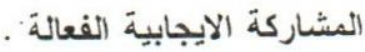

: أسيلوب حل المنتيكلة وهى طريقة جيدة للوصول إلى النتائج والأنار و اقتتر اح الحنول

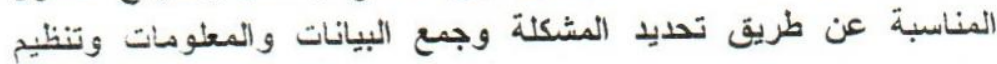


المغلومات وتصنيفها ، عرض المعلومات وتقديمها ، الموصول إلى نتانج وتقايم الحلول الممكنة واختيار الصالح منها فهى عبارة عن الاراسة ، و التخطيط ، التنفيذ ، القويد .

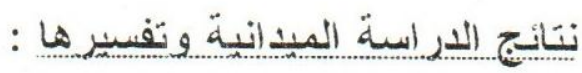
نعرض لنتائج الدراسة على الوجه التالى :

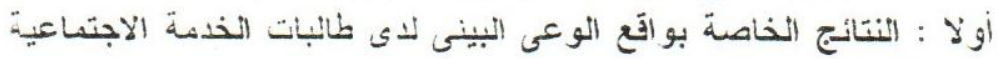

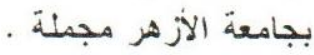
تانبا : النتائج الخاصة بالمحور الأول : الموارد البيئية وعلاتة الإنسان ثنالثا : النتائج الخاصة بالمحور الثنانى : المشكلات البيئية : أسبابها

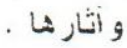
رابعا : النتائج الخاصة بالمحور الثالث : كيفية مواجهة المشكلات البيئية .

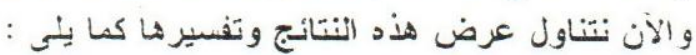

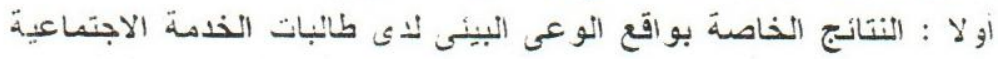

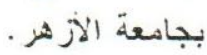

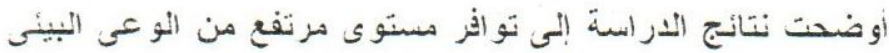

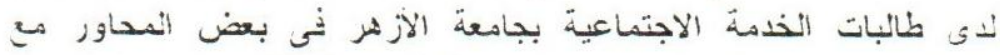
اختلانف مستويات هذا الو عى بين مدأور المقياس الثذلانة.

جذول رقمّ ( (1) يوضح إجمانى استجابات أفر اد عينة الدراسة على محاور التوعى البيئي الثثلاثة

\begin{tabular}{|c|c|c|c|c|c|c|}
\hline \multirow{2}{*}{ سنسنَّ $=$} & \multirow{2}{*}{ إنسنَجابات } & \multicolumn{2}{|c|}{ النسنجابات أخاطند } & \multicolumn{2}{|c|}{ الأستَجاباتَ انصحيحةً } & \multirow{2}{*}{ أسمدزز } \\
\hline & & الخمبنة \% & البند & النسبنة \% & النعذد & \\
\hline ر رَنفِ & $\therefore 2$. & $\%+r, q$. & $1: \Lambda$ & $\% \vee \div .1$. & $r . r$ & الأوزل \\
\hline مرنفع & vo. & $\%$ : & 1.0 & $\% \wedge i$ & $i \leqslant 0$ & الثتانى \\
\hline منتوسط & A.. & $\%$ rq, ro & $r r \leq$ & $\% \vee \cdot, v \circ$ & דו & المثاثث \\
\hline هر تفع & $r \ldots$ & $\%$ r $\{$.ro & $\lfloor A V$ & $\% \vee \Delta, i s$ & $101 \%$ & الجملة \\
\hline
\end{tabular}




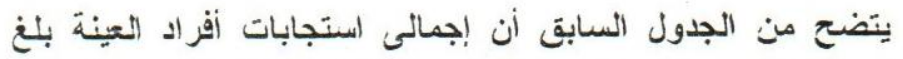

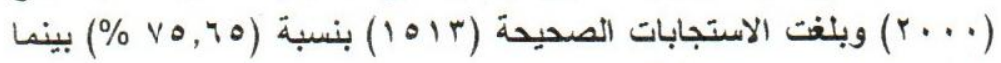

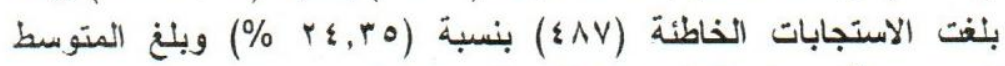

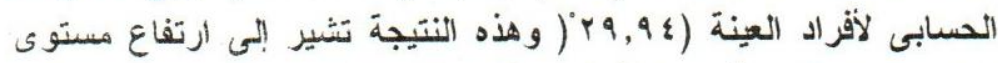

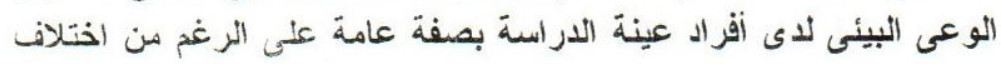

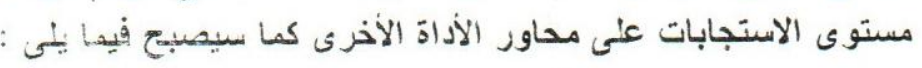
أ- ففى الميحور الأول والخاص بتعرف أهمية الموارد البيئية لبلانسان

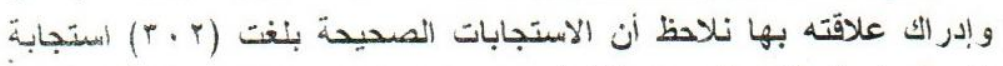

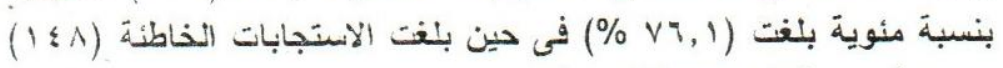

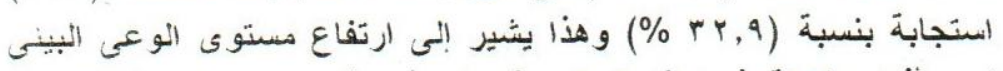

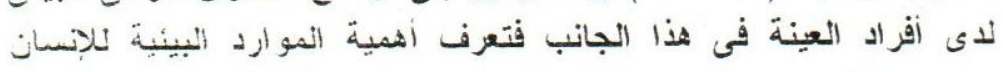

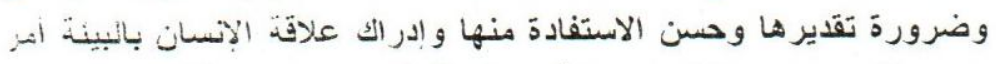

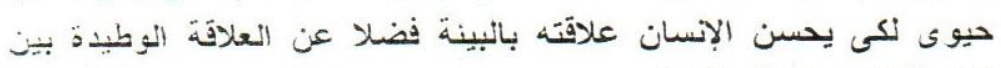
الخدمة الاجتماعية و البيئة الإنيان

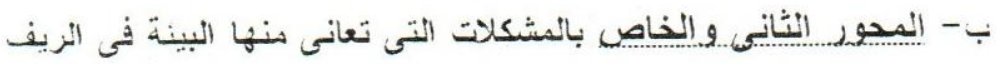

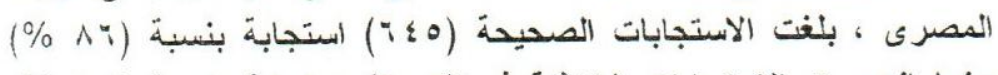

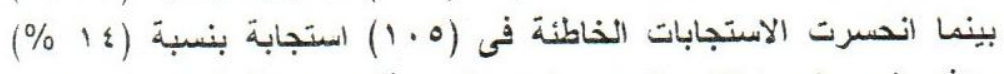

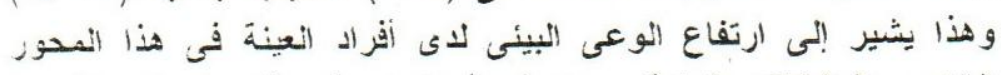

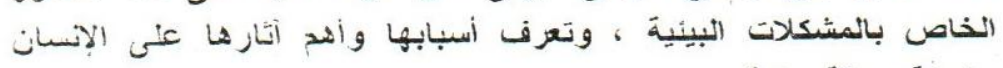
و البيئة بصفة عامة . بالمثلت

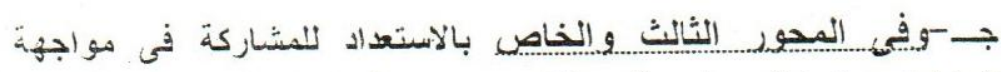

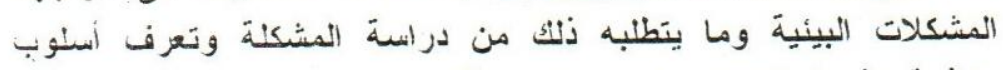

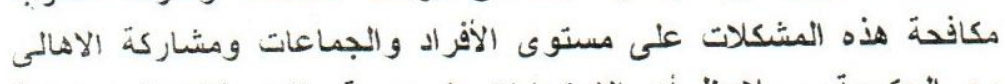

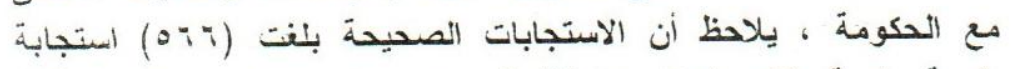

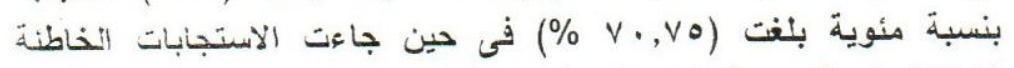

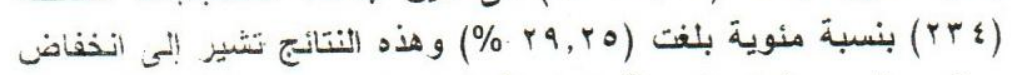

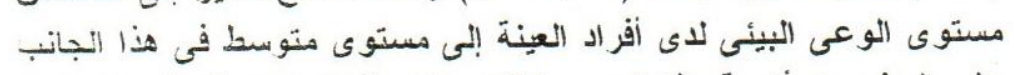

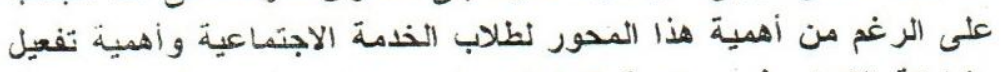

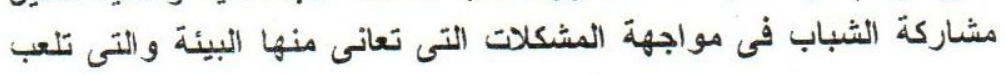




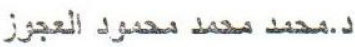

المشاركة دوزا موما في مكافحة هذه المشكلات .

و الآن نعرض لهذه النتائج الخاصة بكل مدور على حدة :

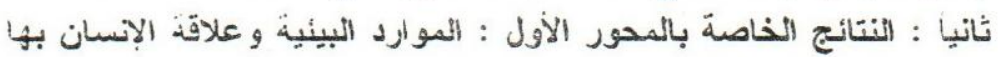

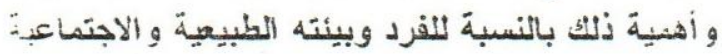

جذون رقم (r) يوضح استجابات أفز اد عينة الار اسة فيما يتعلق بالمحور

الأول : المو ارد البيئية وعلائة الإنسان بهات الاسليا

\begin{tabular}{|c|c|c|c|c|c|c|c|}
\hline \multirow{2}{*}{ 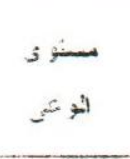 } & \multirow{2}{*}{ 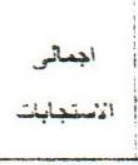 } & \multicolumn{2}{|c|}{ الإنسنجبنبنتة } & \multicolumn{2}{|c|}{ الأستجابيتت } & \multirow[t]{2}{*}{ العبارة } & \multirow{2}{*}{ 光 } \\
\hline & & اننسبة \% & ألعند & هنسبة \% & المعند & & \\
\hline 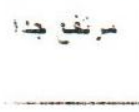 & ○. & $\% \Lambda$ & $:$ & $\% \uparrow r$ & 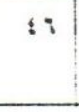 & 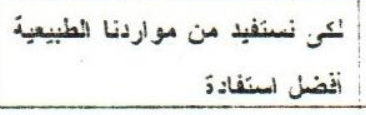 & 1 \\
\hline مسر سط & $\therefore$ & $\%$ \% & $\because:$ & $\% v r$ & $m:$ & عنى أنر غم من كثر مُ الحديث عن & ; \\
\hline خســ & s. & $\% i$ & $r$ & $\%:$ & $r$. & 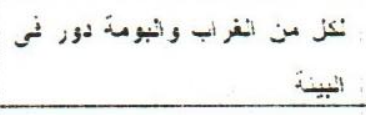 & . \\
\hline- & $\therefore$ & $\% 1$ & ? & $\% i$ & $: 2$ & 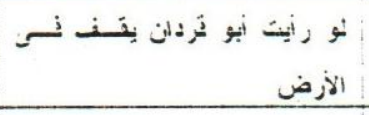 & ir \\
\hline- & $\therefore$ & $\because: 1$ & $\cdots$ & $\%$ \% i & $r a$ & 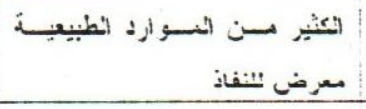 & ir \\
\hline$\therefore=$ & 2. & $\%$ & $:$ & $\% 9$ १ & $\therefore$ & النشجار ثميني البيئة & $\therefore$ \\
\hline ضبيف جـا & $\circ$ & $\% \vee r$ & $r$ & $\% \times A$ & $1:$ & خروج أمر أذّ إلى المعل & $1:$ \\
\hline خبذ & $\therefore$ & $\%$ or & $r:$ & $\% \leq \wedge$ & i: & أنضضل اسنفادْد من طلتحَ المشس & ir \\
\hline بر بن- & $\therefore$ & $\% 1:$ & $\wedge$ & $\% \wedge:$ & $\vdots$ & 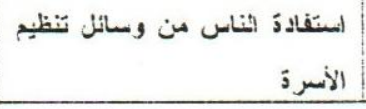 & $r \wedge$ \\
\hline ميندي & $\leq$ & $\%+r .9$. & $\because \vdots$ & $\% \vee \div 1$ & $r \cdot r$ & - لــالى & الاجبت \\
\hline
\end{tabular}

نلاحظ من الجدول السابق أن إجمالى عدد الاستجابات الصحيحة

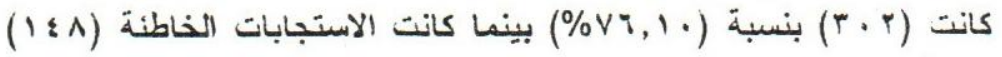

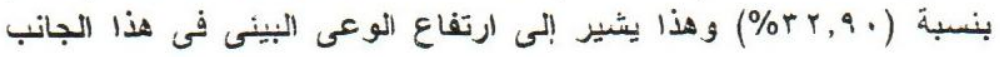


المنصل بعلاقة الإنسان بالبيئة ومواردها و إدراكه بأهمية البيئة بمختلف

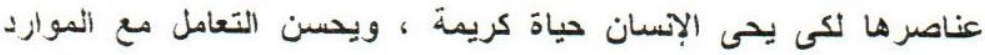

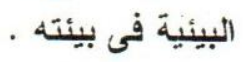

ويمكننا تناول مناقتشة عبارات هذا المحور التسعة كسا يلى :

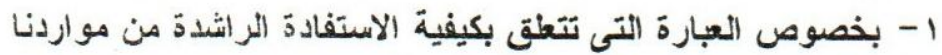

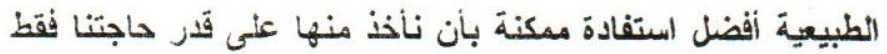

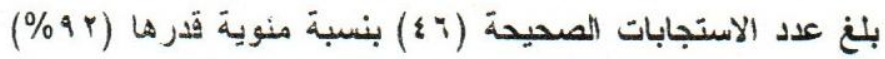

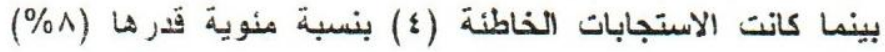

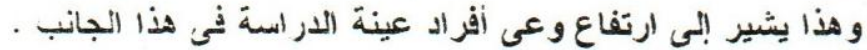

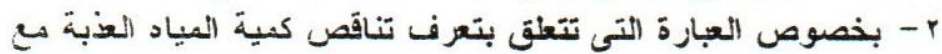

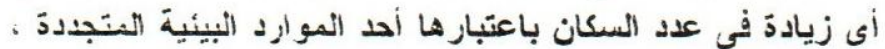

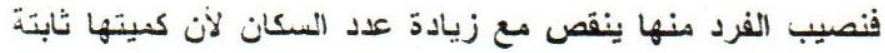

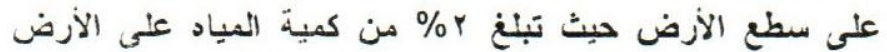

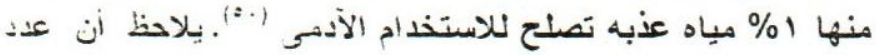

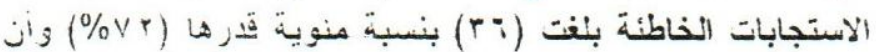

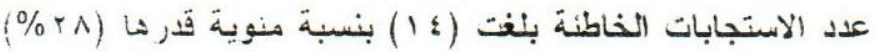

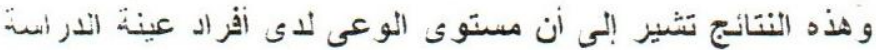
بهذا الجانب جاء متوسطا على الرغم هن أهمية المبياه النغنية للإنسان و الززر اعة وضرورتها للتنمية

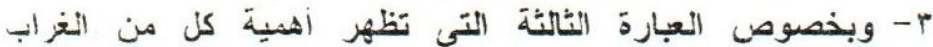
و البومة فيما يتعلق بالبيئة، نلاحظ أن عدد الاستجابات الصحيحة

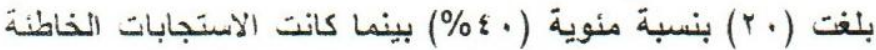

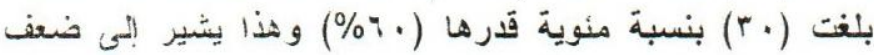

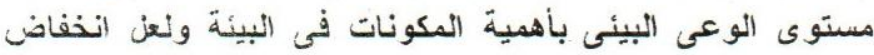

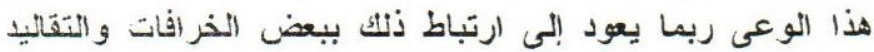
الخاطئة المرتبطة بالبيئة والتى تنشر أكثر فئل في القرية من خلال الموروثات الثقافية كالأمثال الثعبية مثل : الثئة

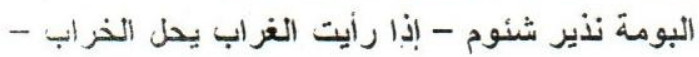

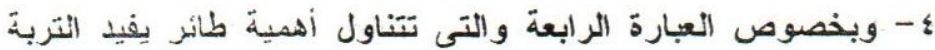

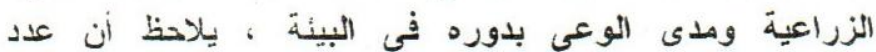

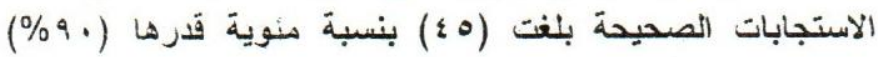


بينما كانت الاستجابات الخاطئة (0) بنسبة منوية بلفت (. (1\%)

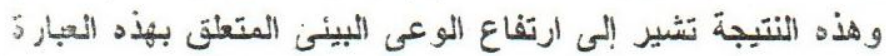

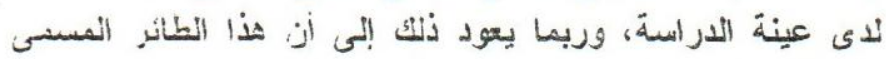

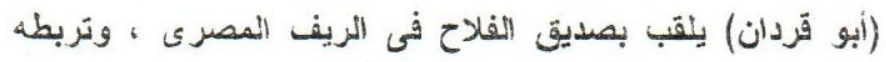

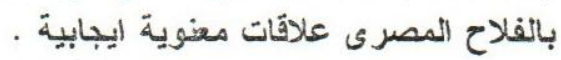

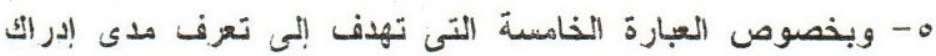

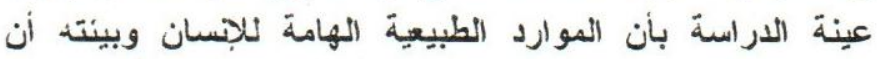

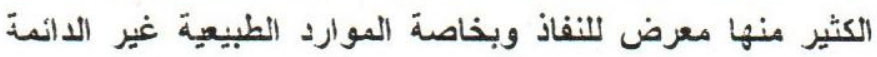

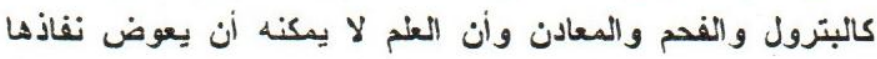

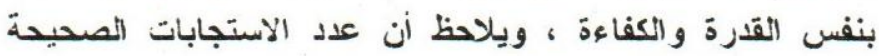

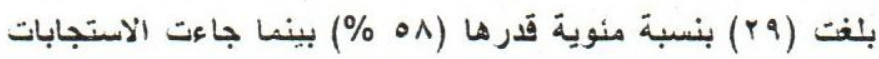

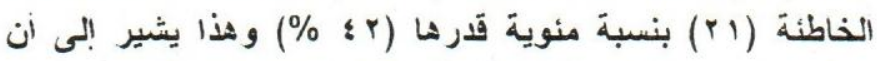

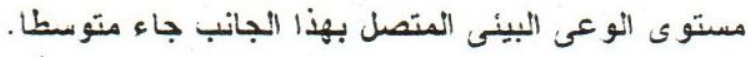

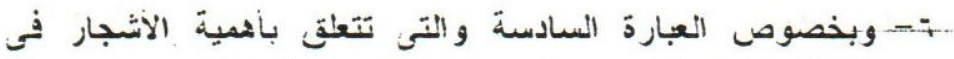

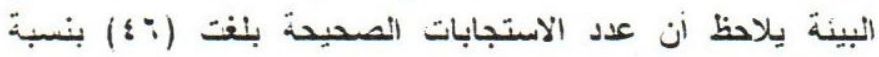

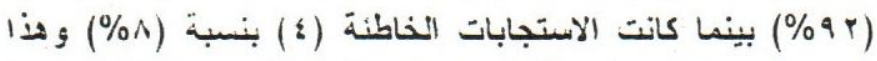

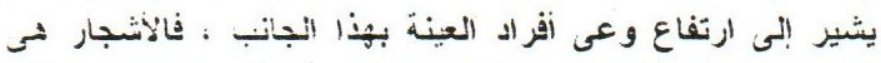

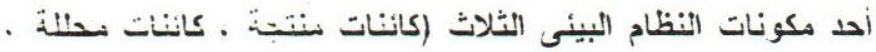

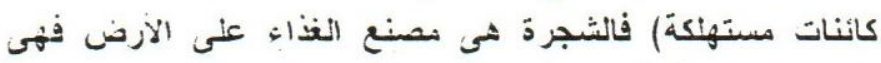

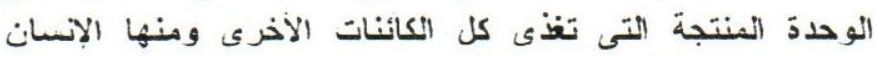

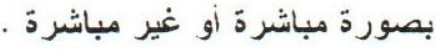

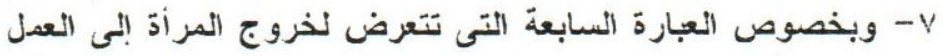

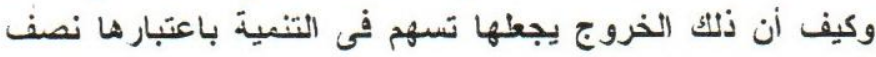

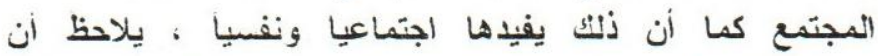

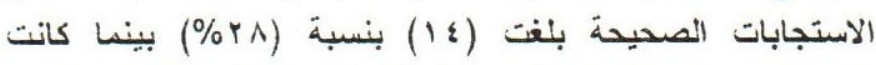

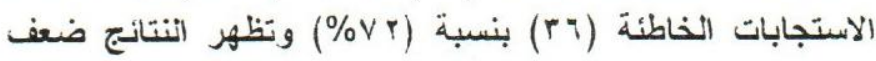

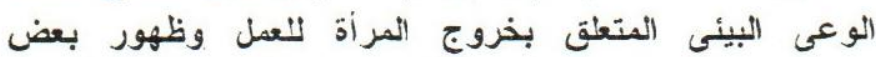

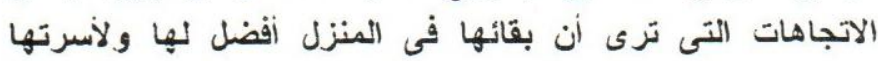

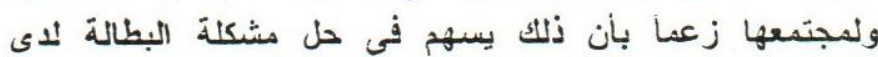

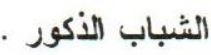


1- وبخصوص العبارة الثامنة والتى تتعلق بأهمية الاستفادة من

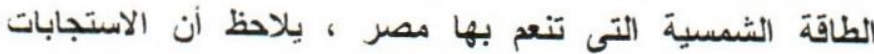
الصحيحة بلغت (ع r) بنسبة (^؟\%) بينسا كانت الاستجابات

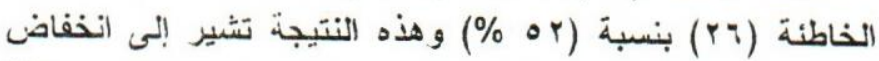

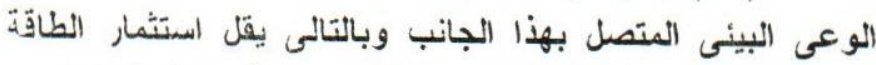

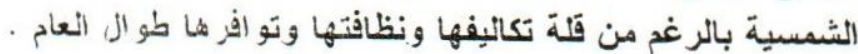

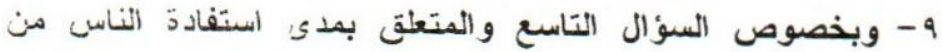

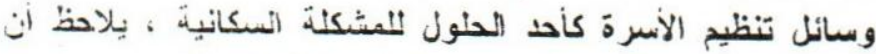

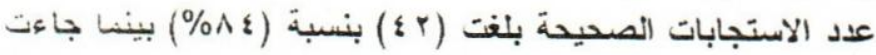

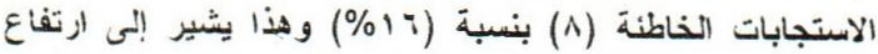

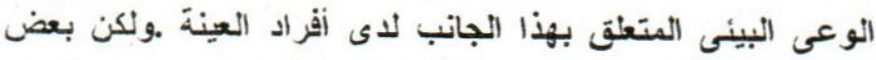

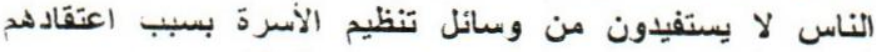

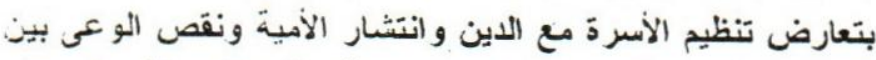

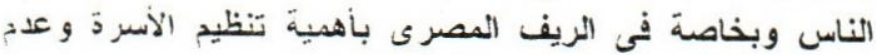

$$
\text { تعارضها مع الدين. }
$$

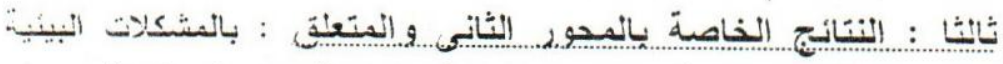
و يعنى بتعرفها وتعرف أسبابها و إدر الثئ خطورتها و أثار ها على النبينة.

جذول رقم (r) يوضح استجابات أفراد عينة الثدر اسة عنى عبارات المدوز

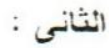

المشكلات البيئية : أسبابها و أنتار نش

\begin{tabular}{|c|c|c|c|c|c|c|c|c|}
\hline \multirow{2}{*}{ - } & \multirow{2}{*}{$\begin{array}{ll}-\infty \\
-1\end{array}$} & \multicolumn{2}{|c|}{ 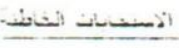 } & \multicolumn{2}{|c|}{ الاستجابات انحسبد } & \multirow{2}{*}{ المبازدة } & \multirow{2}{*}{$\lambda$} & \multirow{2}{*}{3} \\
\hline & & $x-$ & 2 & $\sim m$ & العتد & & & \\
\hline مزنفي & $\therefore$ & $\% \cdot n$ & 9 & $\% \wedge r$ & $\because 1$ & 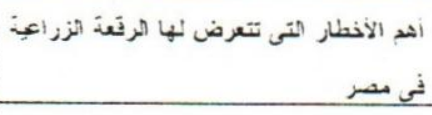 & & r \\
\hline 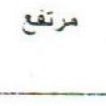 & 2. & $\% 1:$ & $\lambda$ & $\% \wedge \varepsilon$ & $\{r$ & كبرة استعسل المبيدات الكيماوية فى الزراعن & & $r$ \\
\hline متوسط & $\therefore$ & $\% r$. & 10 & $\% \vee$. & ro & من أسباب المشكلة السكانبة في مصر: & & $\leq$ \\
\hline مزتفع بـ & 0. & $\% \wedge$ & 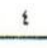 & $\% 9 r$ & i: & التبول فى المجرى المائى أو القرب منه: & & $\circ$ \\
\hline مرتفى & $\therefore$ & $\%$ & ir & $\% \vee v \varepsilon$ & $r v$ & تجريف الأرض المزراعبة & & $A$ \\
\hline
\end{tabular}


لد.محد محمد محسود العجوز

\begin{tabular}{|c|c|c|c|c|c|c|c|}
\hline - & 2. & $\%$ ir & i & $\% \wedge A$ & $i t$ & امستراز هزياذة لسكاتية في مصر بِسبب : & $\therefore$ \\
\hline 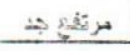 & 2. & $\%$ : & $r$ & $\%$ १: & ¿A & أبتلهارسبا تصبب الإنسان بسبب : & $\because$ \\
\hline مرتفع بـ & $\therefore$ & $\% \&$ & $r$ & $\%$ \%: & 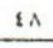 & تتنوث مباد الثترع بسبب & 10 \\
\hline من & 2. & $\% r:$ & in & $\%:\{$ & rr & لينتج عن انتشار البعوض أمراض & iv \\
\hline$\Delta \dot{\Delta i n}$ & o. & $\%$ r. & 1. & $\% \wedge$. & $\varepsilon$. & وند استخدام مكبرات الصوت فى المناسبات & $r$ \\
\hline مرتفع جد & ○. & $\% \wedge$ & i & $\%$ qr & : & يتلوث الهواء من : & ro \\
\hline مرتفع جذ & $\circ$. & $\% \wedge$ & : & $\%$ १ & i: & يصاب الإسلن بذيذان الإسكارس بسبب & $r$ \\
\hline مرنفع جدا & $\circ$. & $\% \therefore$ & $i$ & $\%$ १r & : : & يودى تلوث لمهو اء "مى : & $r i$ \\
\hline مرتفى جـ & $\circ$. & $\%:$ & $r$ & $\%$ 9: & iv & 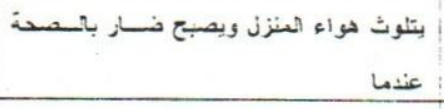 & $r$ \\
\hline مرنفي بـ & 2. & $\%:$ & $r$ & $\%$ a: & : & ينتج عن الثتخين : & $r a$ \\
\hline ر تفي & vo. & $\% 1:$ & 1.0 & $\%$ i: & $\therefore: 2$ & & الاجد \\
\hline
\end{tabular}

بالنظر إنى انجدول النسابق نلاحظ ان عدد الاستجابات الصحيحة

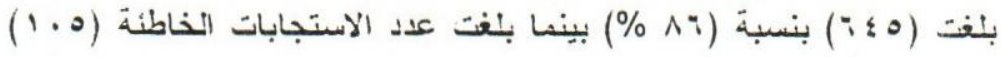

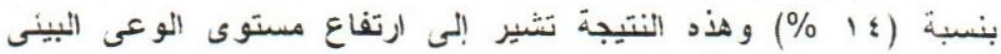
المتصل بالمنثكلات تعانى منها البيئة من حيث تعرف أسبابها وأهد النتائج

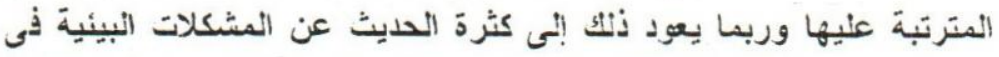
مختنف وسنائل التربية النظامية وغير النظلية ، فضية فئلا عن أن القرية

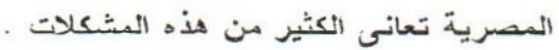

ويمكنا تناول استجابات أفزاد العينة على عبارات المحور الثانى كسا بئى :

1 - بخصوص العبارة الأولى والتى تتعلى بأهم الأخطلى التى تتعزض ألتى

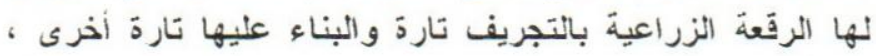

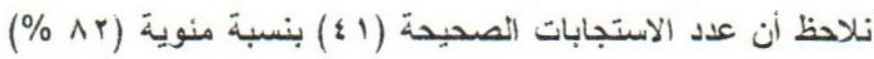
بينما كانت الاستجابات الخاطنة (9) بنسبة مئوية (1 ا ع \%) وهنا يشير إلى ارتفاع مستوى الوعى النيئس المتصل بهنا الجانب: لانق

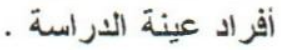
r - وبخصوص العبارة الثانية والتى ترى أن كثرة استعمال المبيدات 
الكيماوية فى الززراعة أدى إلى تلوث التربة والماء و التهواء

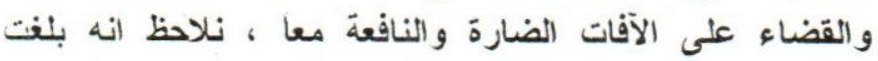

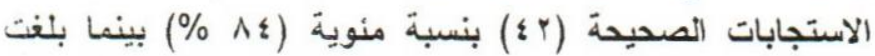

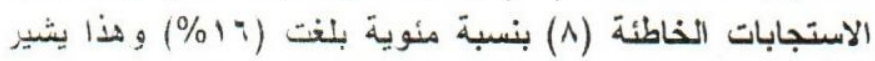

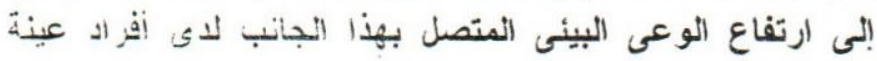

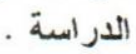

r- وبخصوص العبارة الثالثة والتى تتناول أسباب المشكلة السكانية

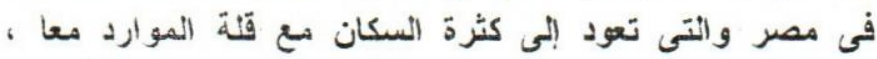

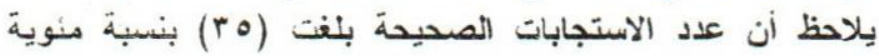

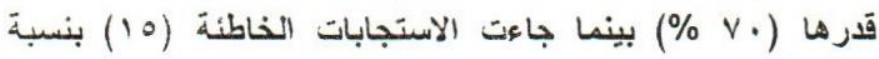

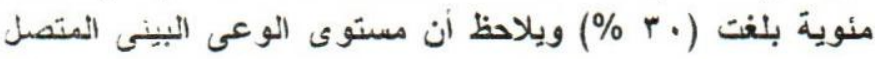

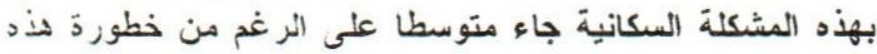

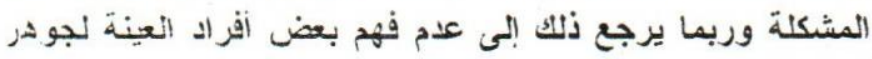

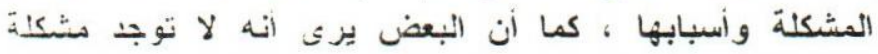

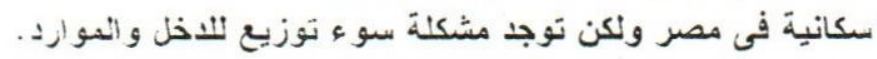

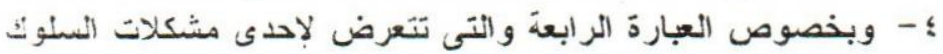

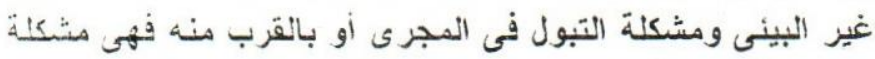

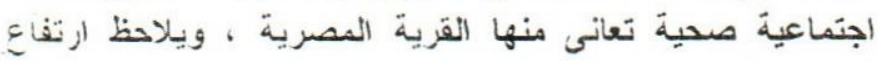

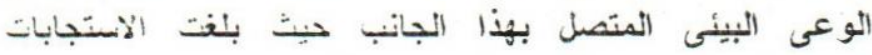

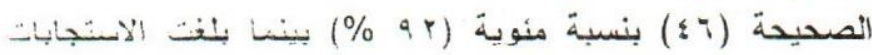

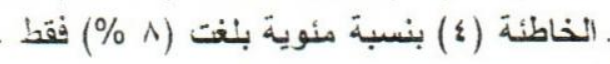

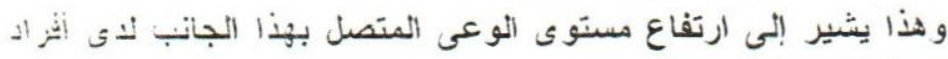

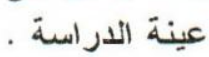
ه- وبخصوص العبارة الخامسة والتى تتناول مشكلة تجريف الارض الزبة

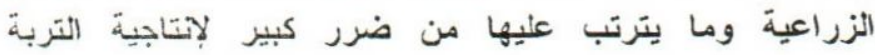

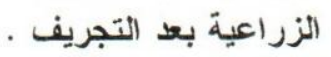

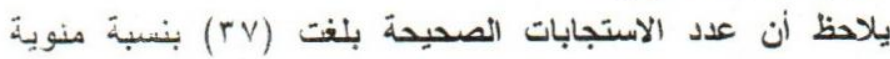

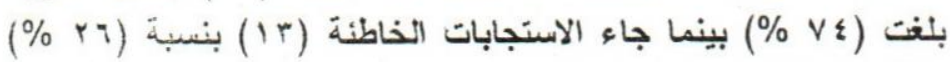

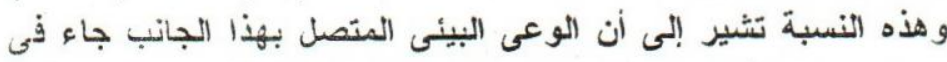

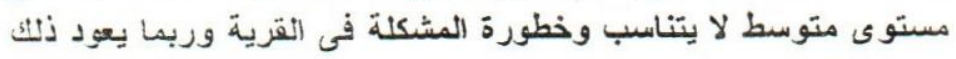

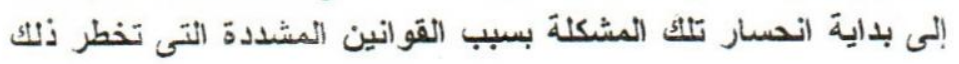




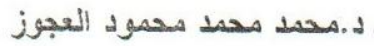

7- وبخمسوص المبارة السادسة والتيى تتعزض لآثار المشكلة المسكانيية في مصر والتى تتمثل فى انخفاض مسنتوى معيشية الفرد ، فضلا

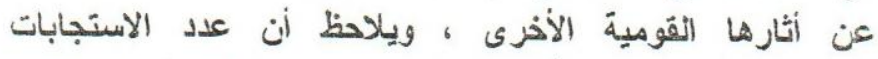

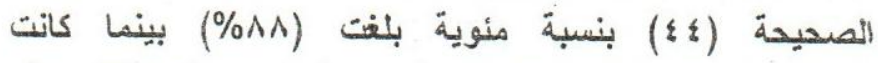

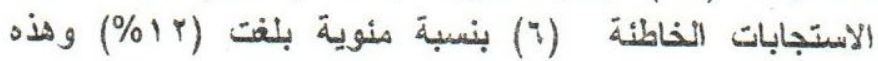
النتائج تشير إلى ارتفاع مستوى التوعى البيئى المتصلة بهنا

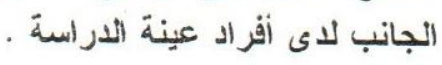

V- وبخصوص العبارة السابعة والتى تتصل بأسباب انتشتار مرض

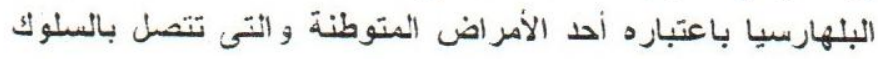

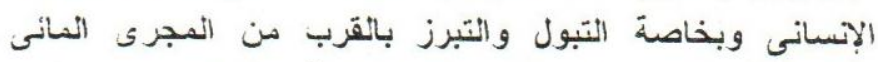

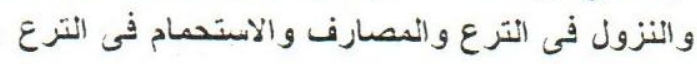

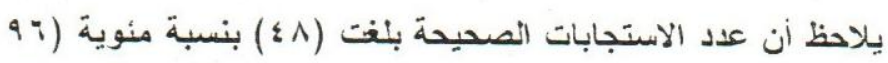

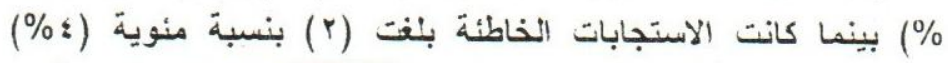

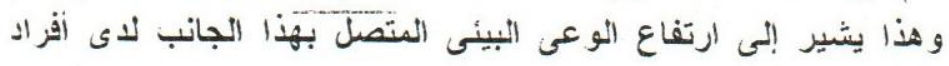

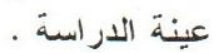

^- وبخصوص المبارة الثامنة و التى تتعرض لمشكلة تلوث مياد التزرع وهى منثكلة فى معظمها سلوكية لان التخوث يعود إنى إلى رسى

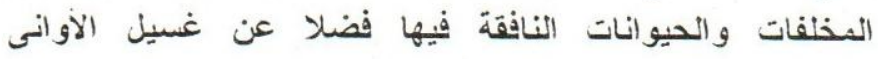
و المهلابس و إلقاء مياه الصرف بهوا ، ويلاحظ ارتفاع مسنوى

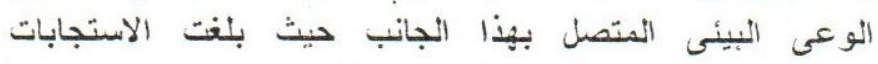

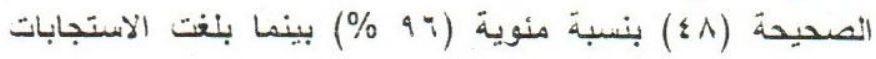

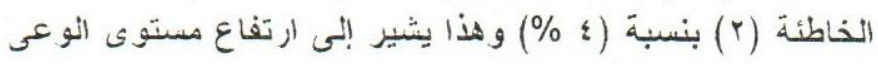

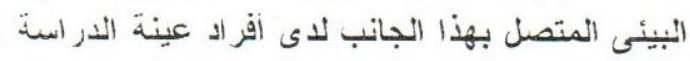

9 - وبخصوص العبارة التتاسعة والتى تتصل بالؤعى والآثار المترتبة

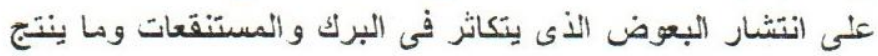
عن ذلتك من أمراض الحميات يلاحظ أن عدد الاستجابات الصحيحة

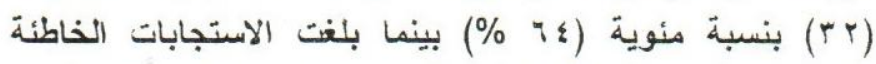

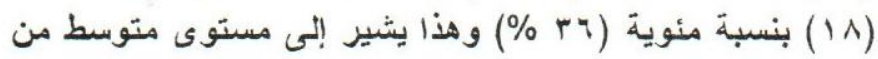




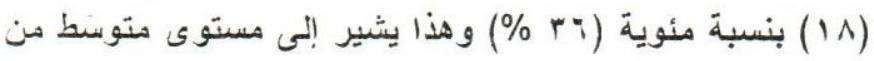

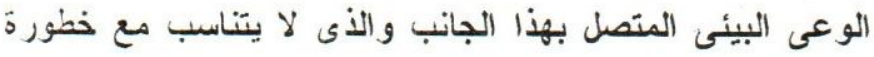

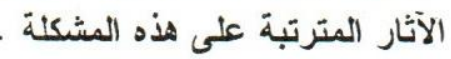

• 1- وبخصوص العبارة العاشرة و التى تتعلق بالتلوث بالضوضاء

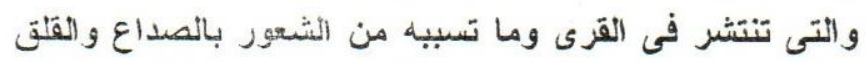

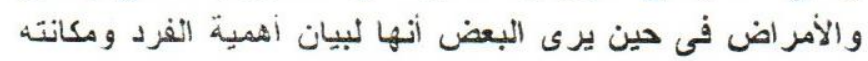

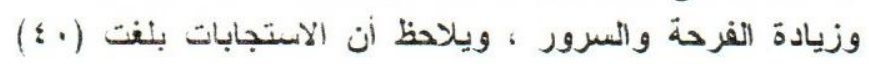

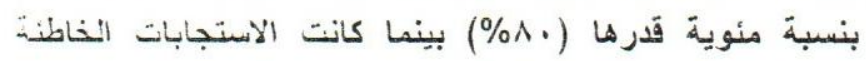

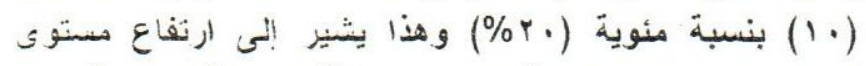

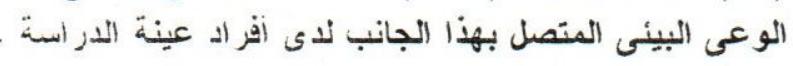

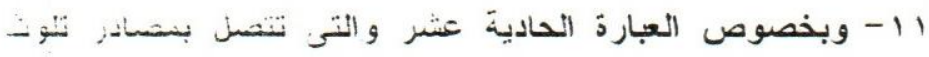

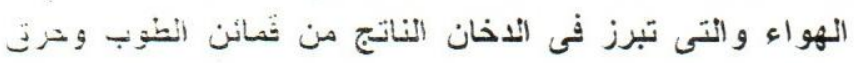

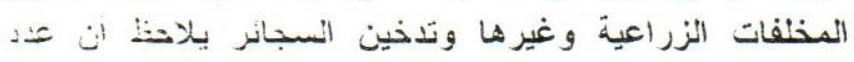

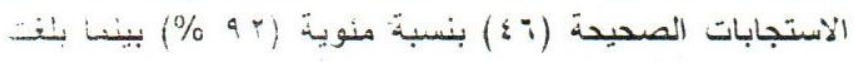

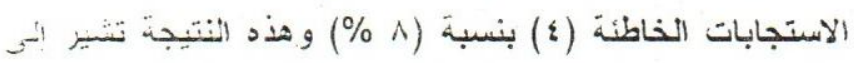

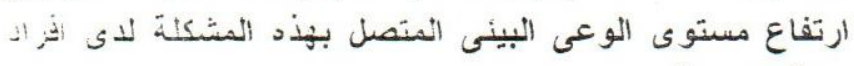

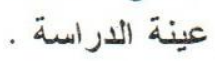

rا- وبخصوص العبارة الثانية عشر والتى تتعنق بالنسباب التسى

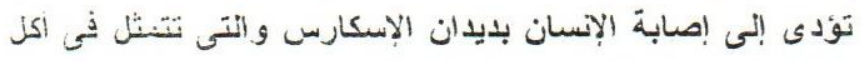

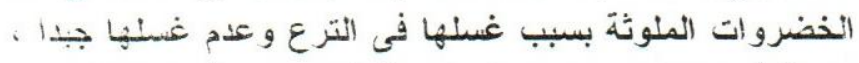

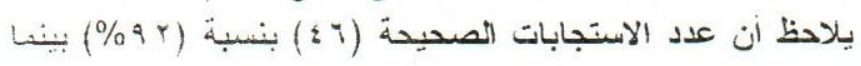

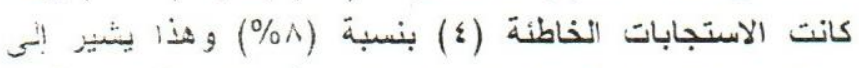

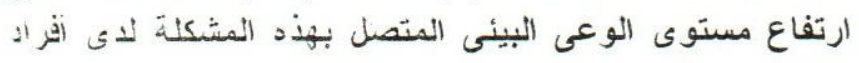

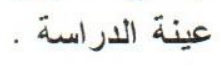

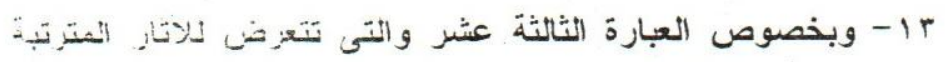

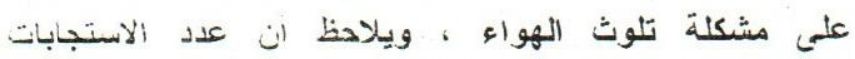

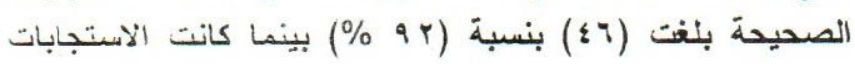

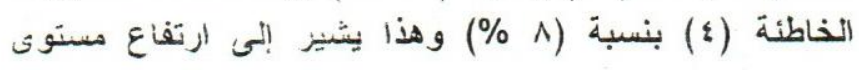




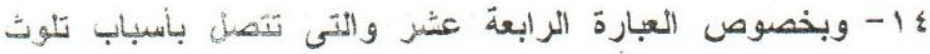

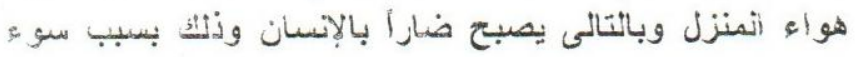

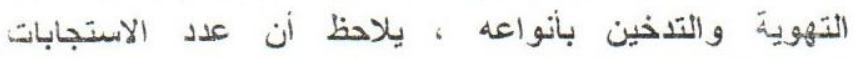

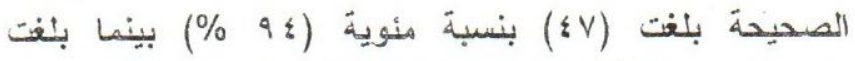
الانستجابات الخاطئة (r) بنسبة (T \% ) و هذا يشيز إلى ارتفاع

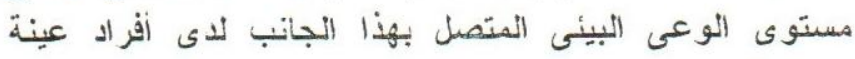
الار اسة.

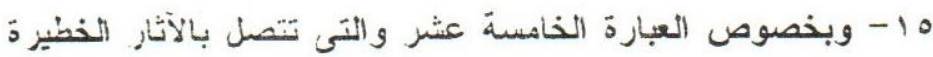

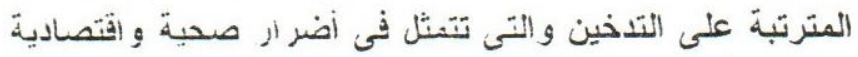

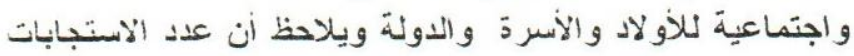

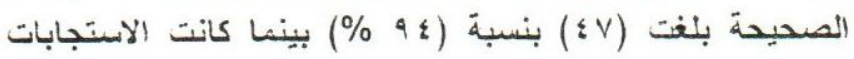

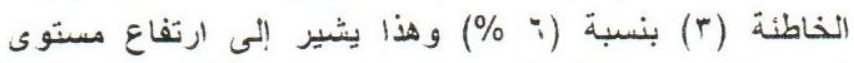

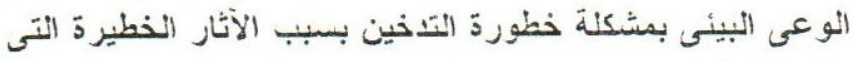
تنتج عنو

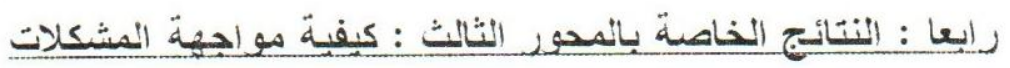

جلول رقمّ (ع) يوضنح استجابات أنر اد عينة اللار اسة على عباز ات

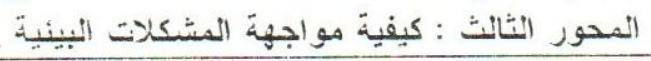

\begin{tabular}{|c|c|c|c|c|c|c|c|}
\hline \multirow{2}{*}{ مسنو تئون } & \multirow{2}{*}{ الاجسح } & \multicolumn{2}{|c|}{ الْسنجبابات الخذطنُ } & \multicolumn{2}{|c|}{ الانسنجب'بات المصديحة } & \multirow{2}{*}{ أنعبازرة } & \multirow{2}{*}{3} \\
\hline & & التسبن \% & المغ: & النسبنة \% & المغند & & \\
\hline ضسيف & 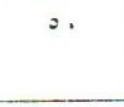 & $\%=A$ & ra & $\% \leq:$ & rY & 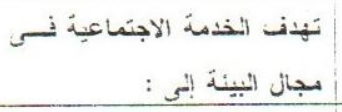 & 9 \\
\hline ثرن & $\circ$. & $\%$ & it & $\% \vee:$ & $r i$ & 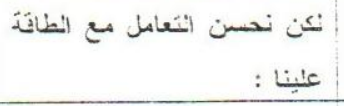 & $1 \mathrm{~A}$ \\
\hline سرت & s. & $\% 1 r$ & $y$ & $\% \wedge A$ & $\therefore:$ & 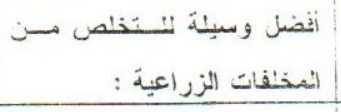 & 19 \\
\hline مرتفى & o. & $\%$ Yr & 11 & $\% \vee \wedge$ & pq & 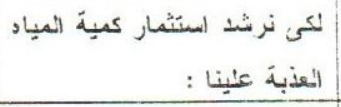 & Y! \\
\hline مرنفع & o. & $\% \backslash \wedge$ & 9 & $\% \wedge r$ & $\leqslant 1$ & تسعى التُربية إلى : & $r r$ \\
\hline
\end{tabular}


انوعي البيئي للى طالبات الخذدة الاجتهاعية بجامعة الأزهز

\begin{tabular}{|c|c|c|c|c|c|c|c|}
\hline مرتف & 0 . & $\% 1 \therefore$ & 9 & $\%$ \%r & $\leqslant 1$ & نَسعى المتربيةَة للهى : & $r r$ \\
\hline هرتفع & s. & \%rr & 11 & $\% \vee \wedge$ & rq & 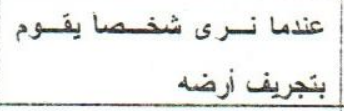 & $r \leq$ \\
\hline مرنفع & o. & $\% r \leq$ & ir & $\% \vee r$ & r & 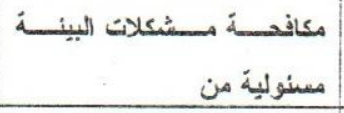 & YY \\
\hline هنربة بنط & o. & $\% \leq \varphi$ & it & $\% \circ \wedge$ & Ys & 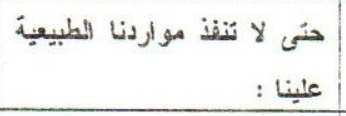 & Yq \\
\hline مرنفع جلا & 0 . & $\% \wedge$ & : & $\% 98$ & 87 & 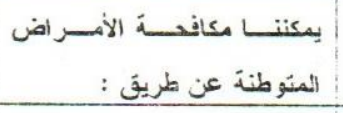 & $r$ \\
\hline مرنفى & s. & $\%: \wedge$ & 9 & $\% \wedge r$ & $\leqslant 1$ & 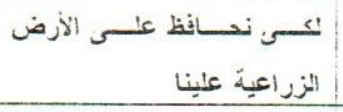 & $r$ \\
\hline- & $\therefore$ & $\% r$ & $\therefore$ & $\% v:$ & $r v$ & 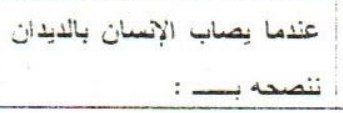 & $r$ \\
\hline$\therefore-$ & $\therefore$ & $\% \leq \therefore$ & $:$ & $\%=r$ & $Y$ & 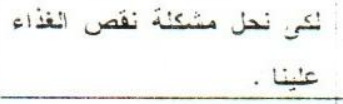 & + : \\
\hline$\rightarrow \leq-$ & $\therefore$ & $\%:$ & ir & $\% 97$ & $\leq \wedge$ & 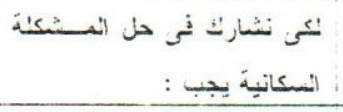 & $r$ \\
\hline 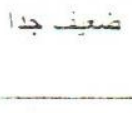 & $\therefore$. & $\% \vee$. & ro & $\%$ & 10 & 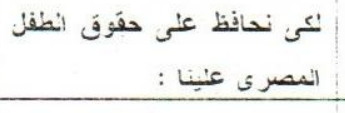 & $r$ \\
\hline ضسيف & $\therefore$ & $\%:$ & $r$ & $\%:$ & r. & 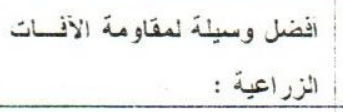 & $-v$ \\
\hline - & $=$. & $\% 1+$ & i & $\% \wedge \wedge$ & $\leq \leq$ & طيكن بكندة الخـندين عـن & 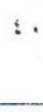 \\
\hline منَّو سط & $\wedge \cdots$ & $\%+\leq .+0$ & $r+5$ & $\% v \cdot . v=$ & $0: 1$ & ith- & \\
\hline
\end{tabular}

بالنظر إلى الجدول السابق نلاحظ أن عدد الّستجابات الصديحة

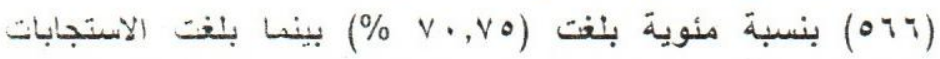

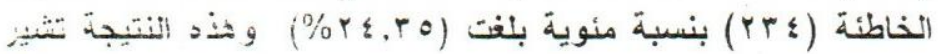

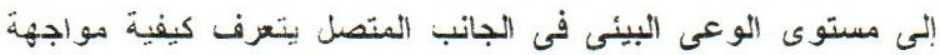
المشكلات البيئية والتأهب للمشاركة في اليجاد حلول لهنئه المشكلات 


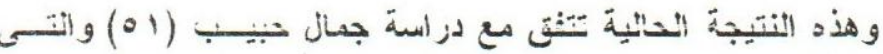

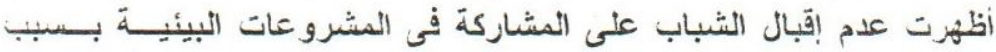

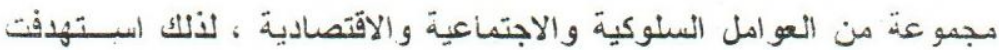

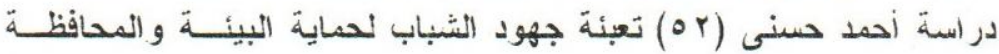

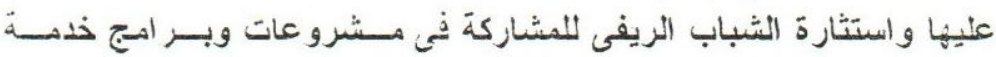
البيئة مع إكساب الثباب مهار ات فنية لحل المشكلات البينية

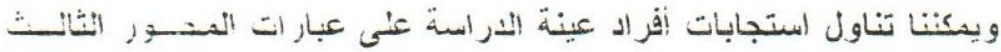
كما بـلئ

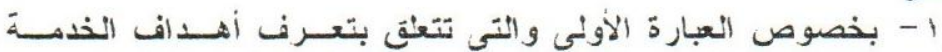

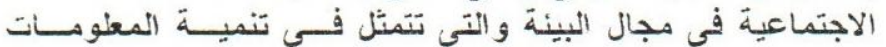

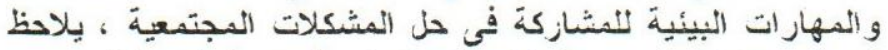

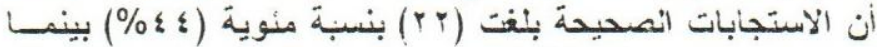

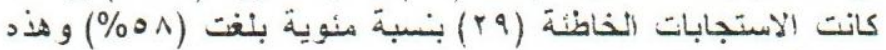

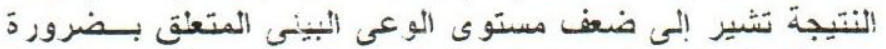

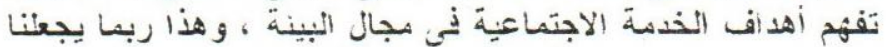

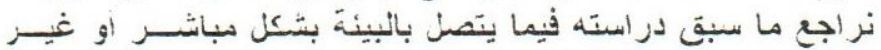

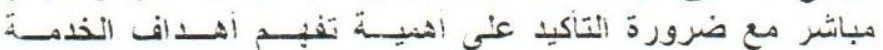

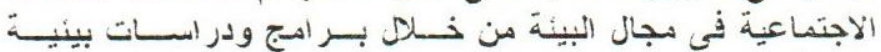

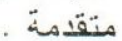

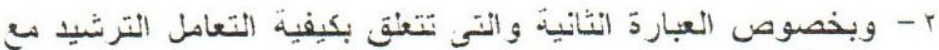

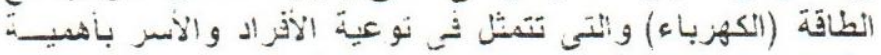

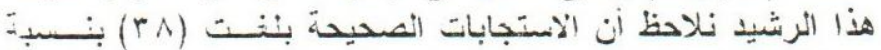

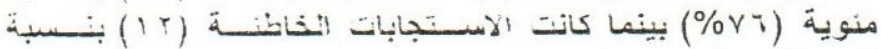

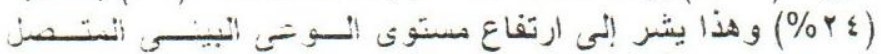

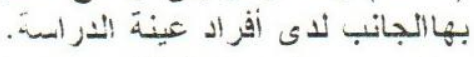

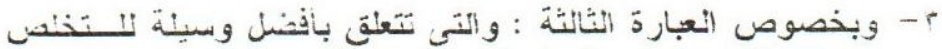

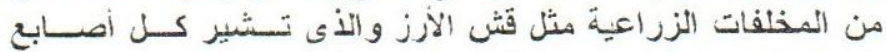

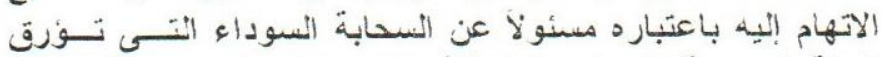

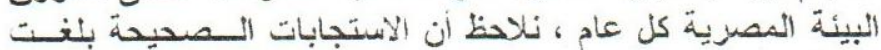

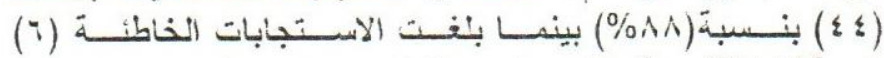

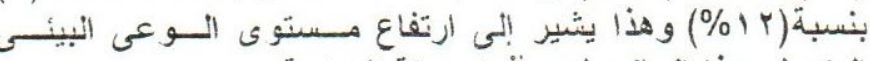

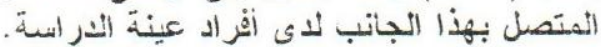

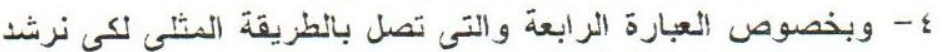

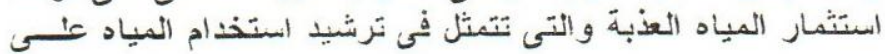




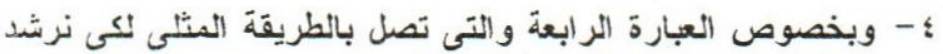

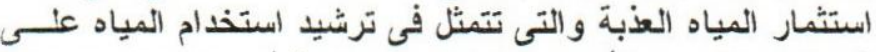

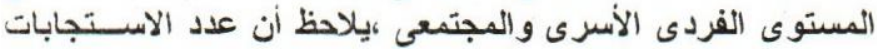

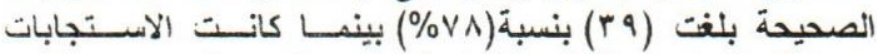

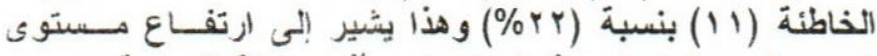

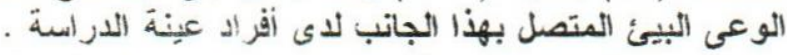

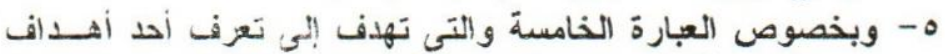

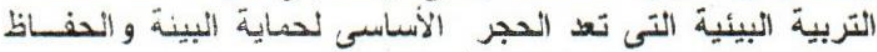

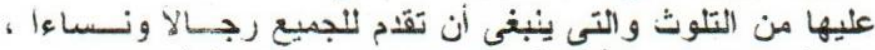

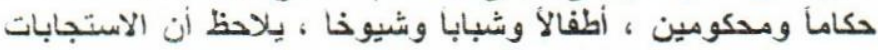

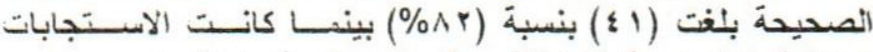

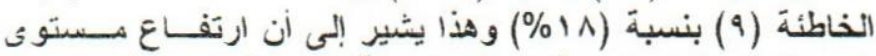

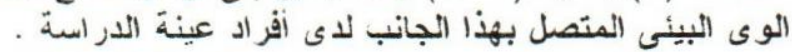

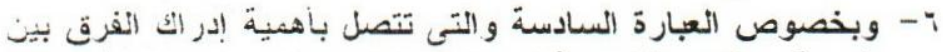

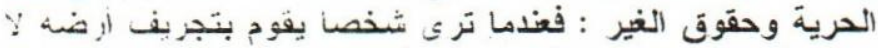

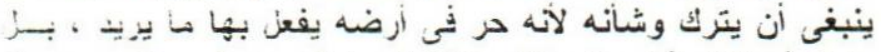

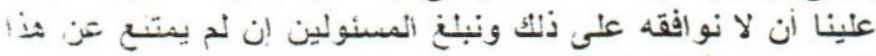

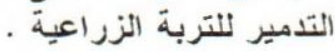

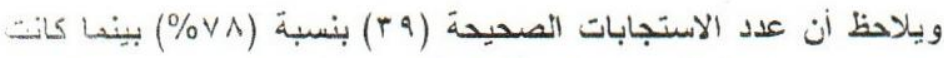

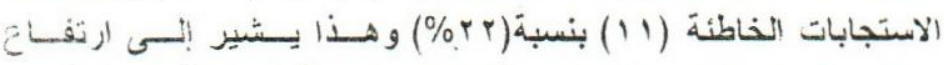

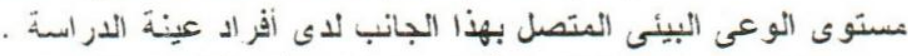

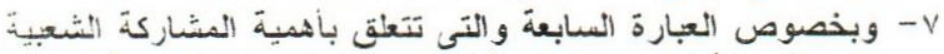

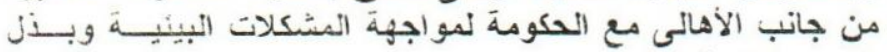

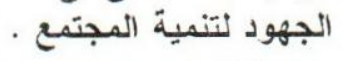

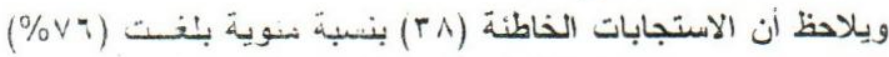

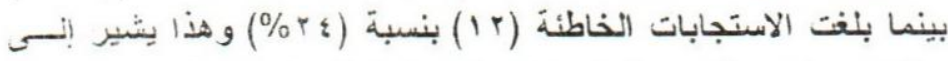

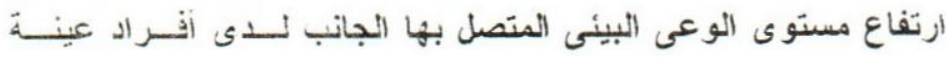

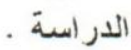

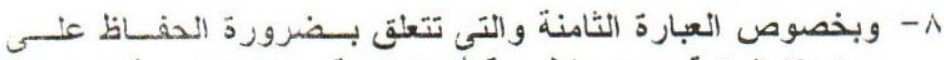

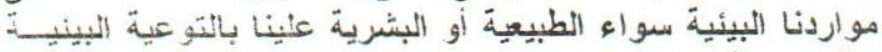

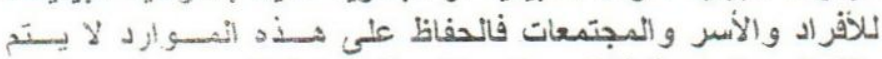

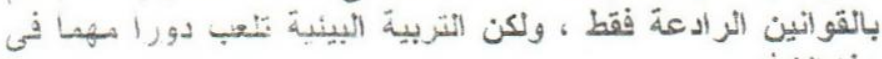

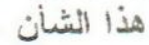

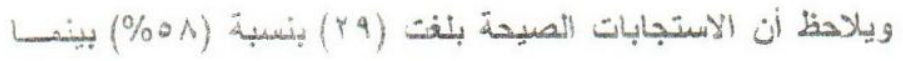




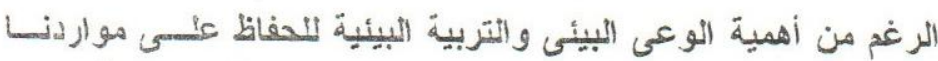

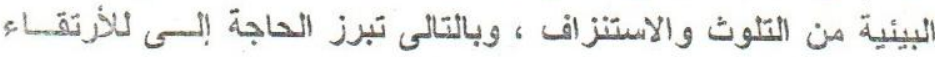

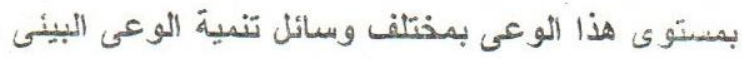

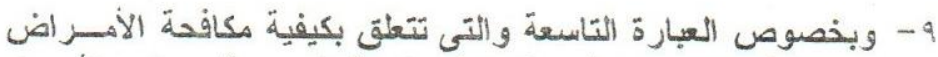

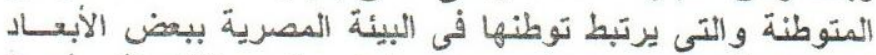

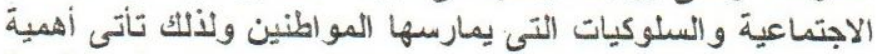

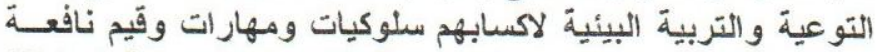

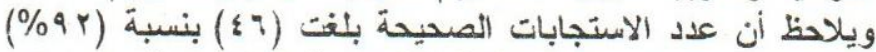

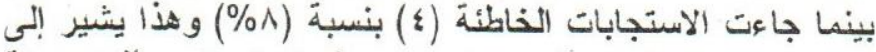

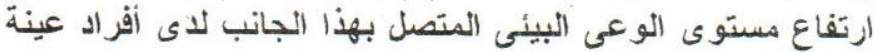

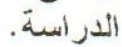

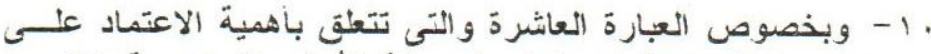

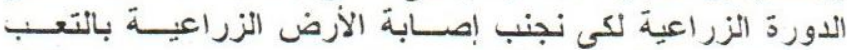

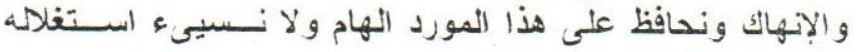

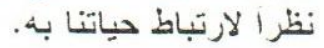

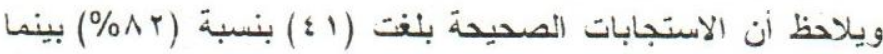

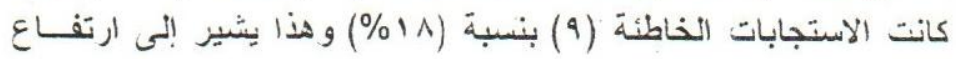

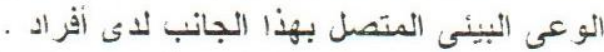

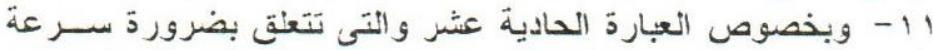

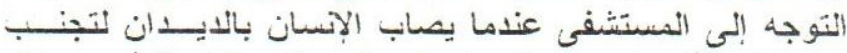

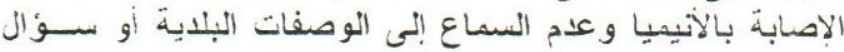

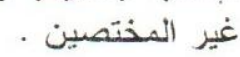

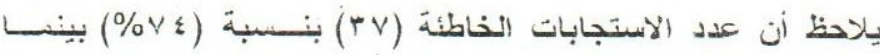

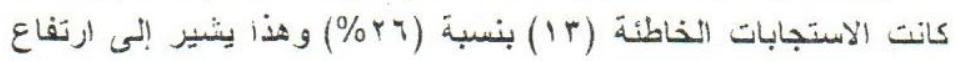

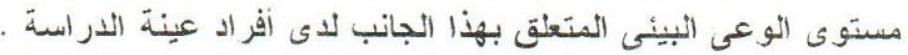

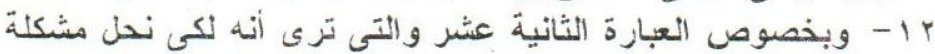

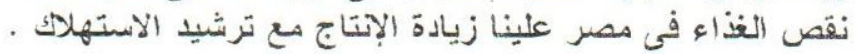

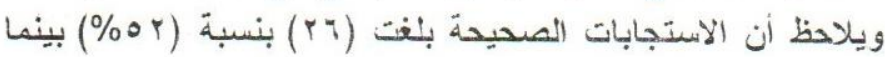

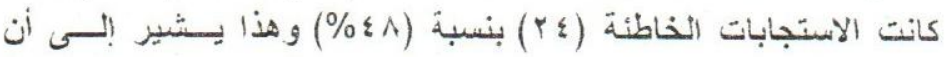

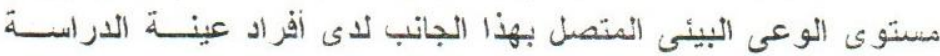

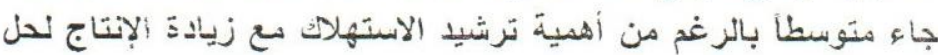

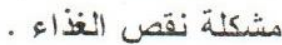


سبكلة نقص الفذاء .

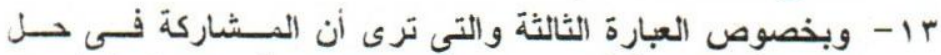

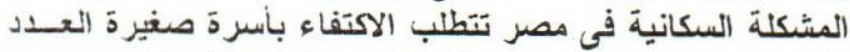

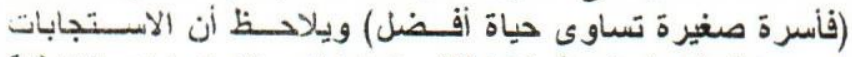

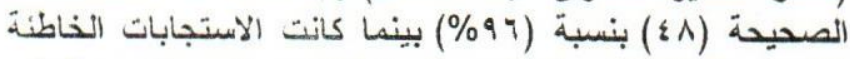

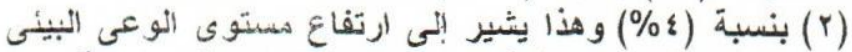

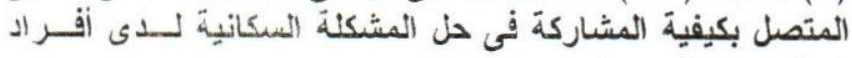

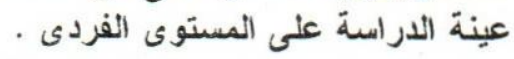

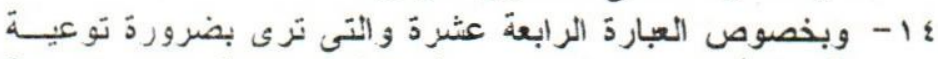

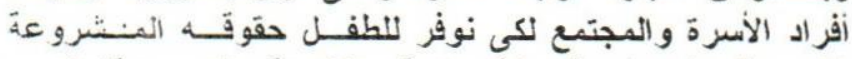

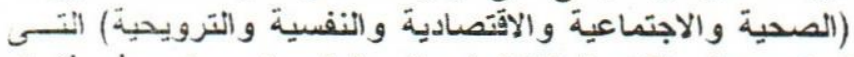

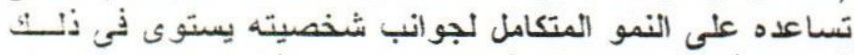

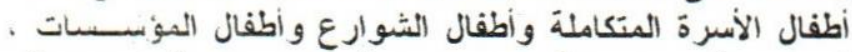

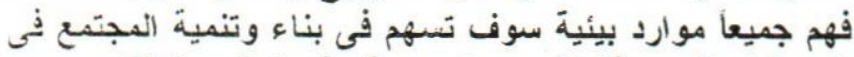

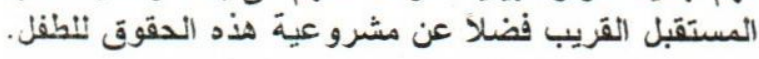

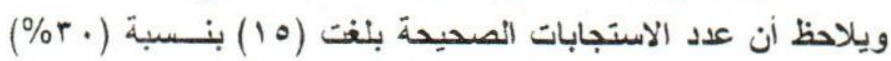

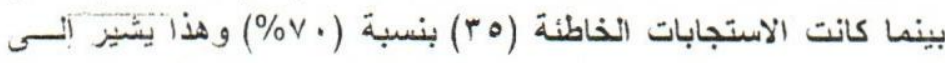

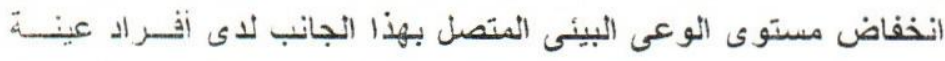

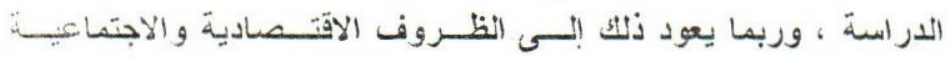

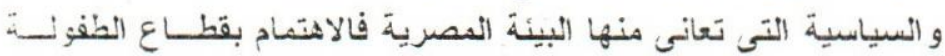

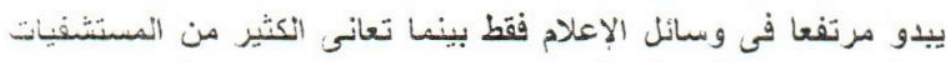

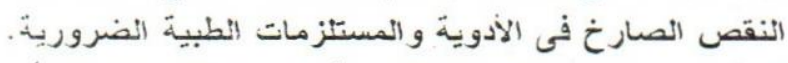

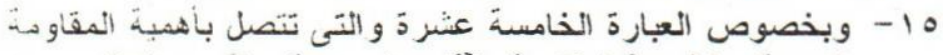

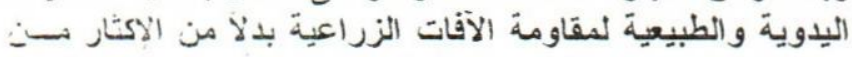

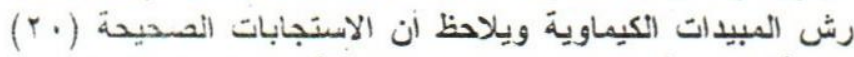

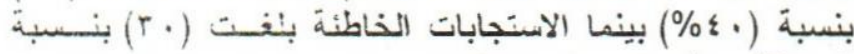

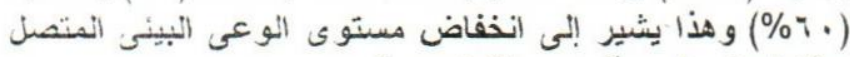

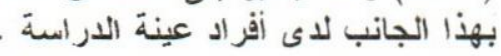

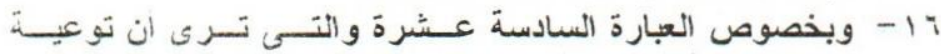

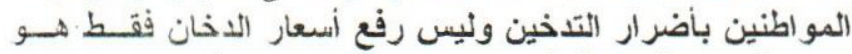

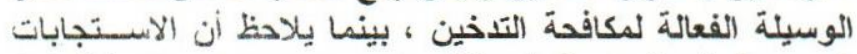

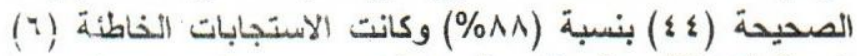

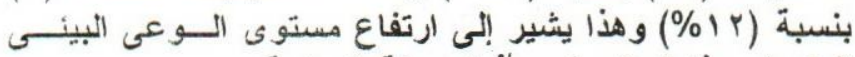
المتصل بهذا الجانب لاى أفراد عينة الدار استة . 


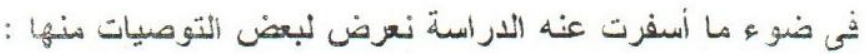

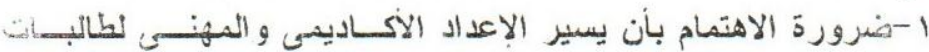

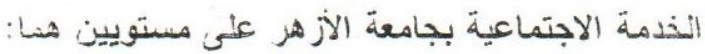

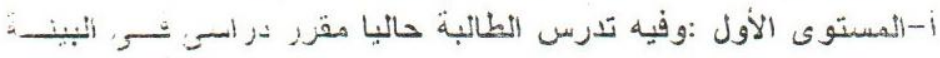

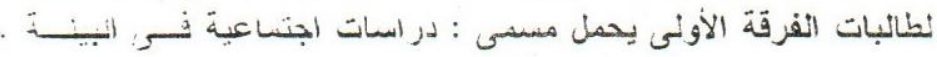

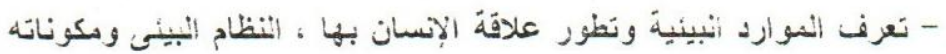

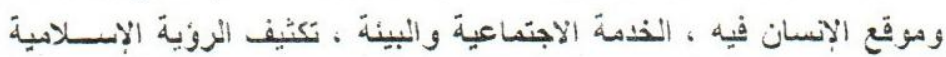

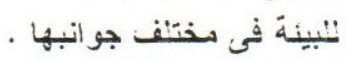

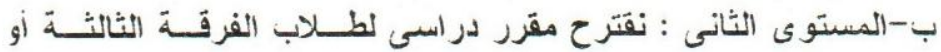

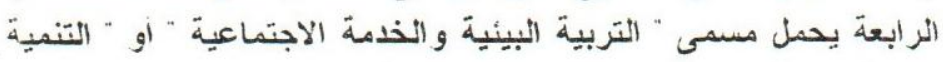

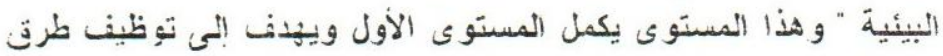

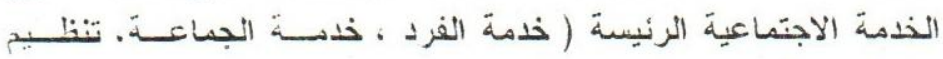

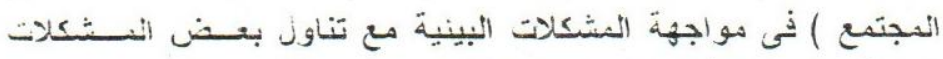

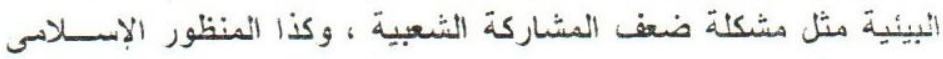

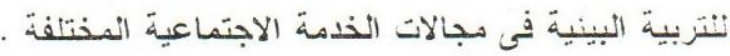

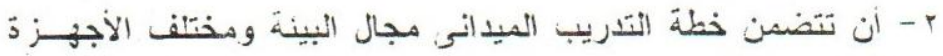

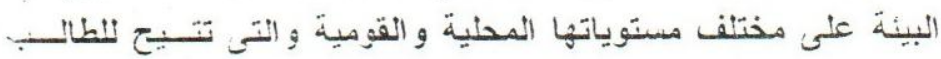

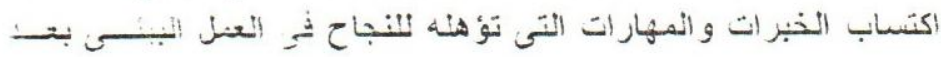
البتخرج

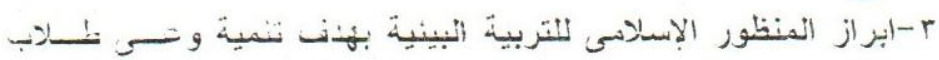

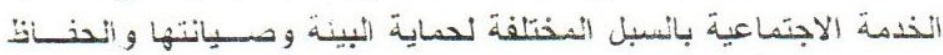

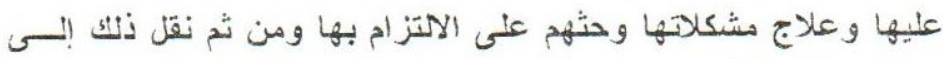

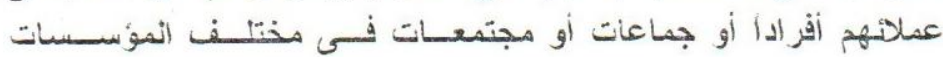

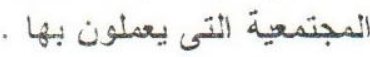

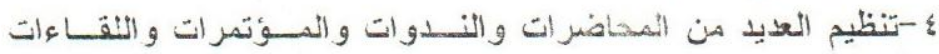

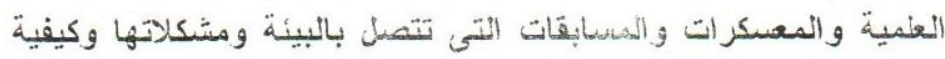

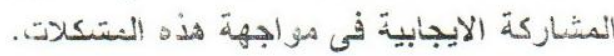

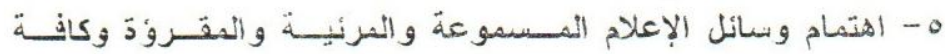

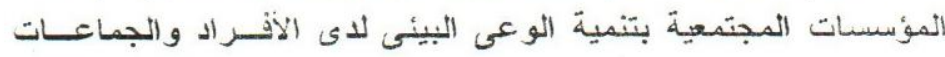


الؤوعي البيئي لدى طالبات الخدمة الاجتهاعية بجامعة الأزهر

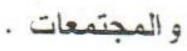

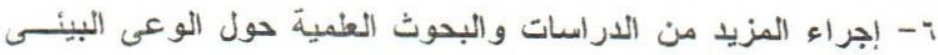

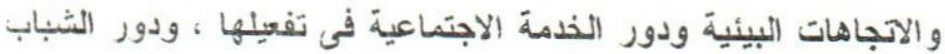

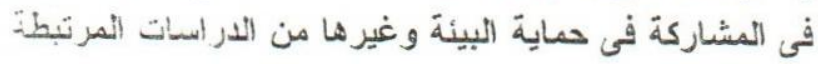

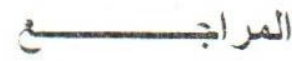

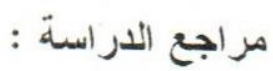

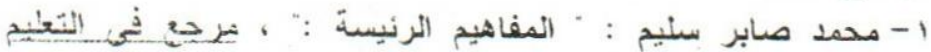

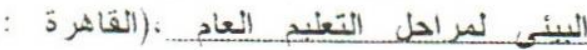
المنظمة النعربية للتربية والئية والثقانة و العُوم

$$
\text { (19VY }
$$

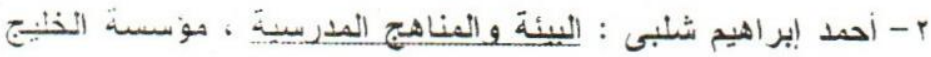

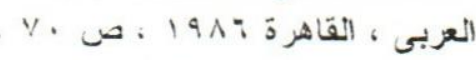

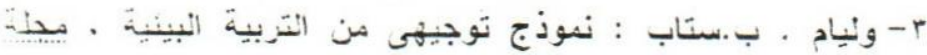

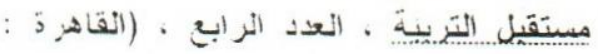

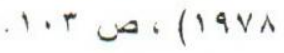

: - سميز عبد القادر خطاب ، عبد الناصر سعيد عطايا : وعى طلانب كلية التربية ببعض جو انب القضايا التوطنية .

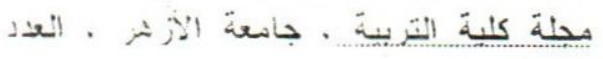

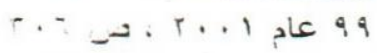

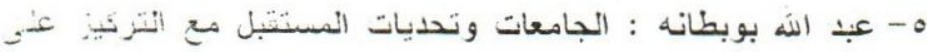

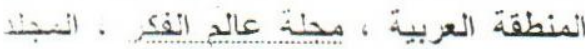

التاسع عشر ، (الكويت : وزارة الإنة الاعلام

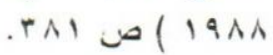

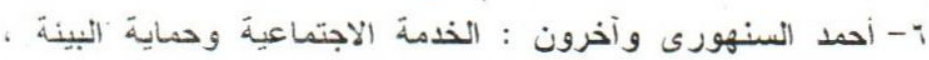

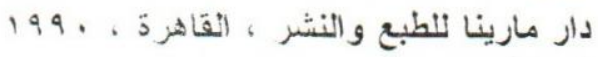

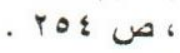

V- الجهاز المركزى للتعبئة العامة و الإحصاء : المجموعة الإحصائية

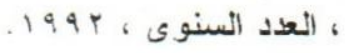

1- دافيذ وثرنجنون : بزامج التتريب البيئى للشباب غير الميقا 


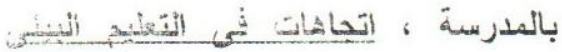

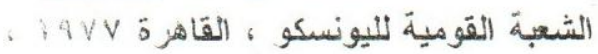

$$
\text { ص . }
$$

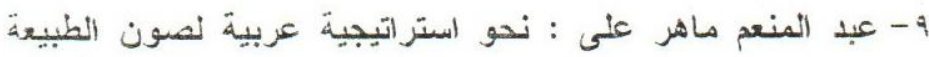

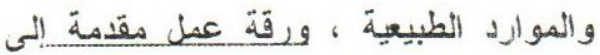

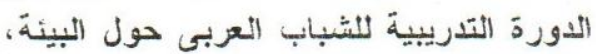

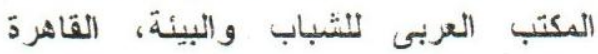

$$
\text { 1.1 1910 }
$$

. 1 - ليوبولا وتشيابو : التربية البيئية و النعالم الثنالث ، ميلة مسيتقبل

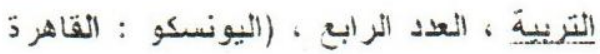

$$
\text { . V. ص ( 19VA }
$$

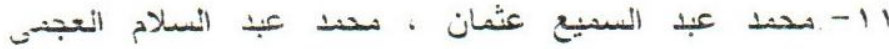
الدار اسات الاجتماعية للبيبة - ينينامبات العمل

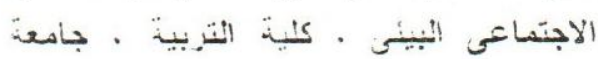

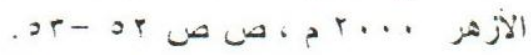

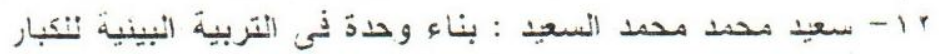

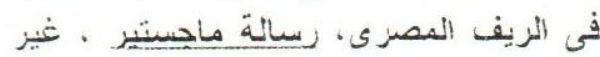

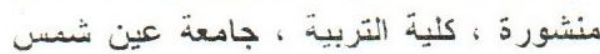

$$
\begin{aligned}
& .191 \text {. }
\end{aligned}
$$

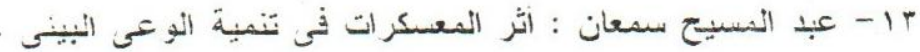

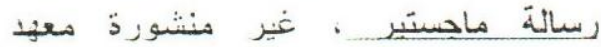

$$
\begin{aligned}
& \text { ألذراسنات و البحوث البيئية ، جامعنة عين فئل }
\end{aligned}
$$

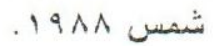

14- Mecay , Roger, and others:"measuring the attitudes and awareness of Environmental lducation compusers, Pocone Enw . Edu. center, I.S.A Pennsyivania. 1988.

15- Kidd, William : Evaluation of an Environmental Education Program, Journal of 
Env . Eda . vo! !e, Ne, 4 . 1978.

17 - فادية حامد مغيث : مشكلة تلوث البيئة ودور التربية فى لى

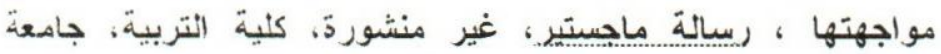

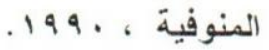
IV

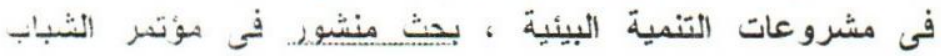

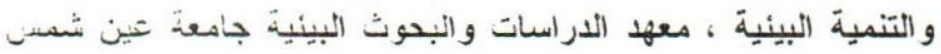

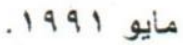

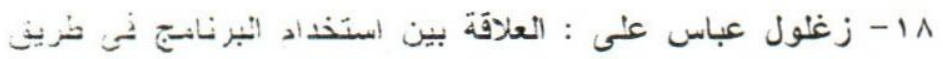

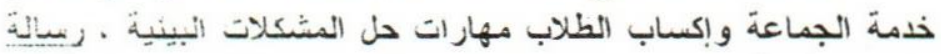

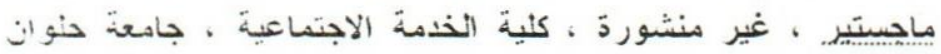
.1994

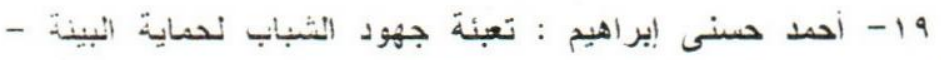

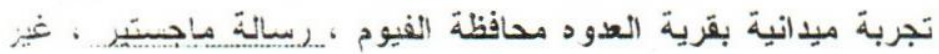

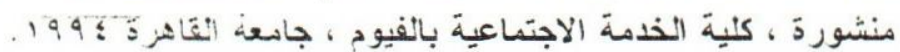

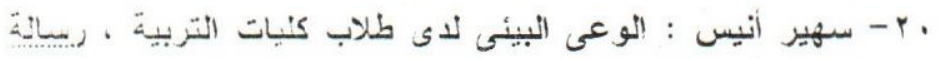

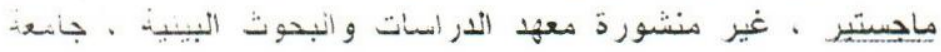

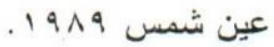
اب- على خليل وفايز عبدد : المواجهات الاسنلامية للتبربية البينية

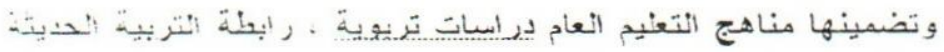

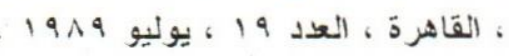

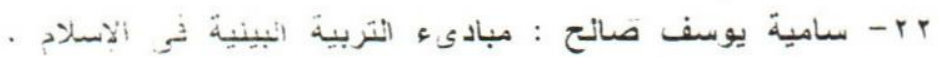

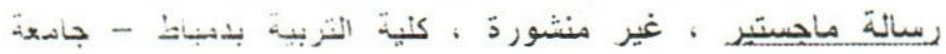

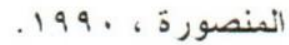

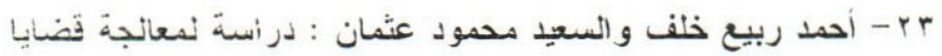

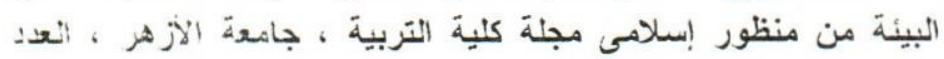

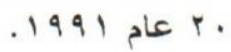
ع ب- السيا هدمد السابح وعلى إيراهيم الاسوقى : إتجاهات أعضلاء

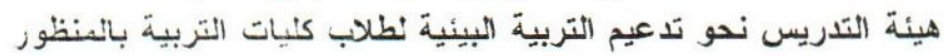

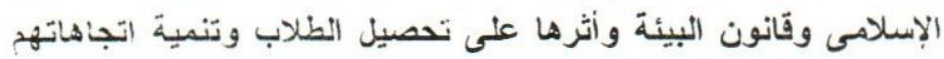


نحو دماية البيئة من التلوث ، مجلة كلية التربية ، جاهعة الأزهر ،

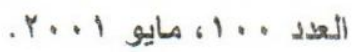

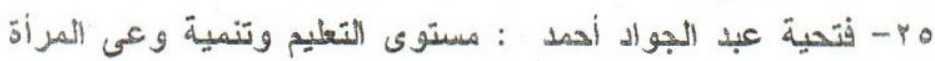

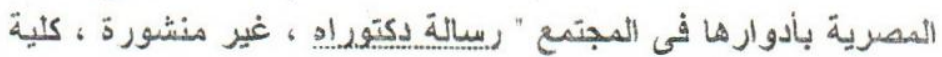

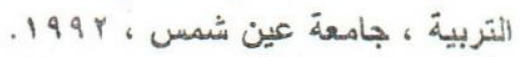

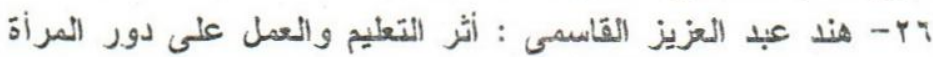

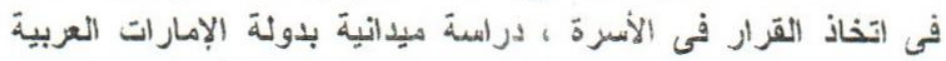

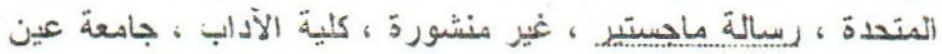

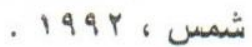

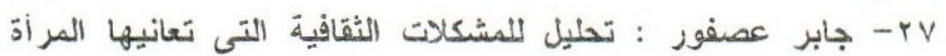

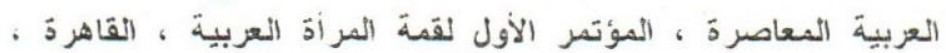

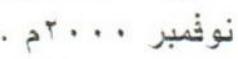
^r - سمير عبذ القادر خطاب وعبل الناصر عطايا ، وعى طنلب كلية

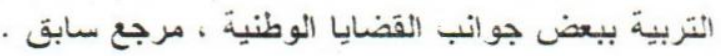

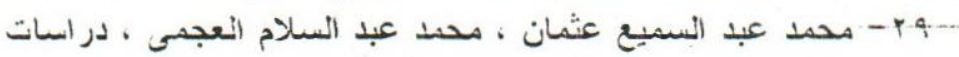

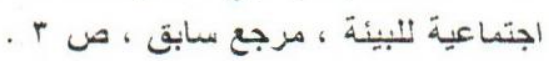

30- David R. Krathwohl :Toxonony of Educational objectives, Hand bookll ,affective domain, New York, 1964, P99.

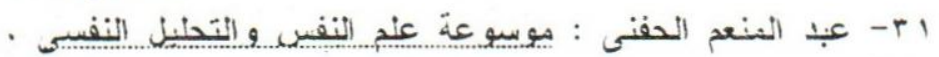

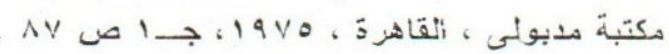

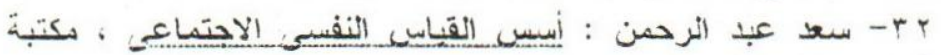

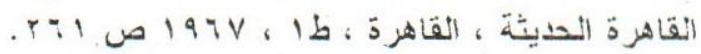

33- John $O$. Steven : Awareness, Exploring, Experimenting, Experiencing, California, 1971, PP 5 6.

؛ آب- جون تايلور : عقول المستقبل ، ترجمة لطفى فطيم ، بينييلة

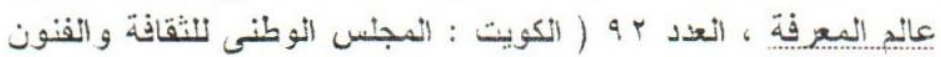

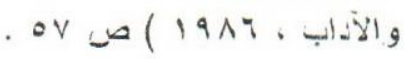

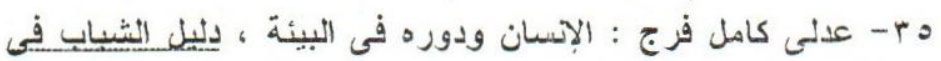

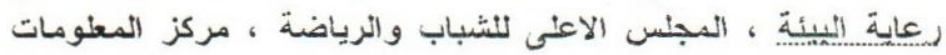




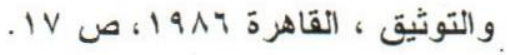

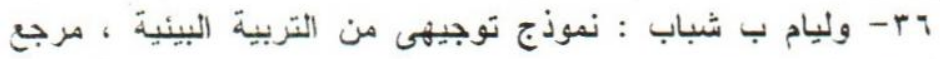

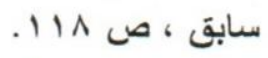

37- William H. Ittelson, Harold M. Proahansky ; An introduction (i) Enuironmental Psychology , Halt Rinhart and Winston Jncg New york, 1974 , P.7.

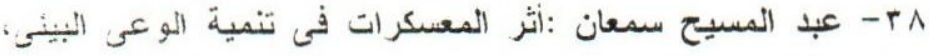

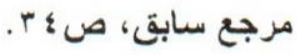

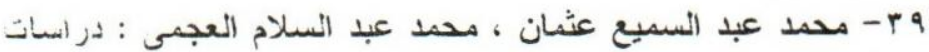

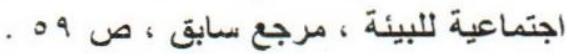

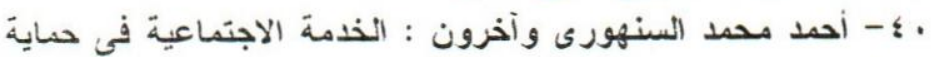

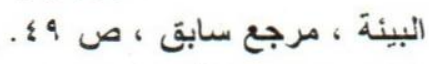

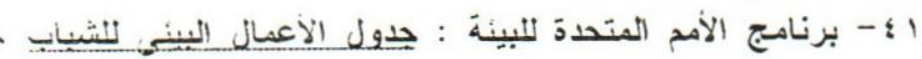

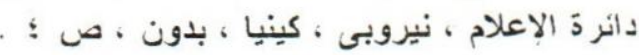

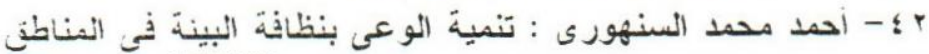

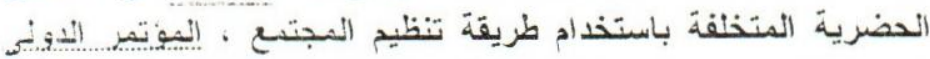
التتابيع للاحصاء والحسابات العلمية والبيحوث الاحتماعية و انسيكانية .

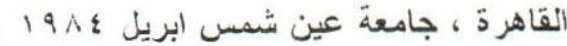

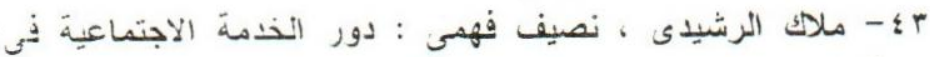

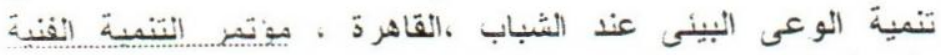

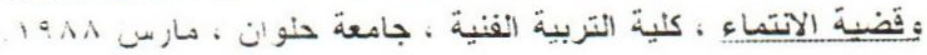

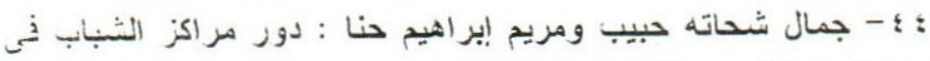

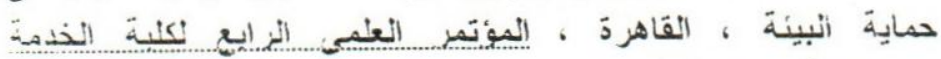

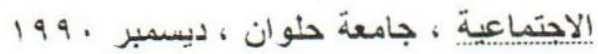

0ـ - نبيل إبراهيم أحمد : اتجاهات طلاب الخدمة الاجنساعية نحز

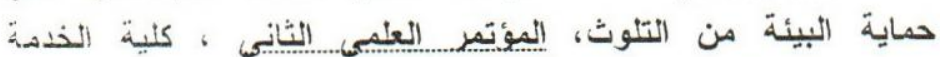

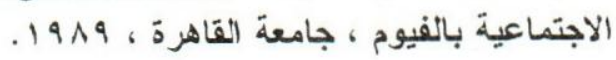

خ ؛ - مصطفى أحمد حسان : دور الأخصائى الاجنماعى فى مجال

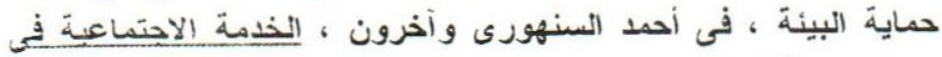

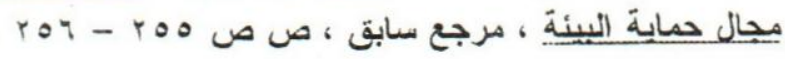


- أحمد أنسنهورى و آخرون : الذذمة الاجنماعية فى هبان همابة

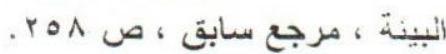

^ـ - محمد نجيب توفيق : نحو إطلار مقترح لقيام الاخصانى

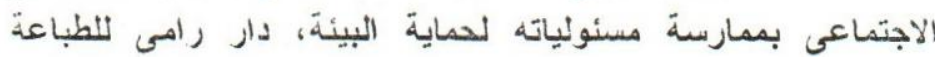

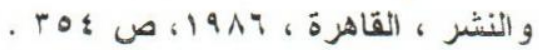

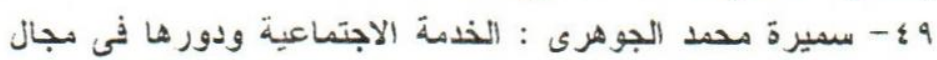

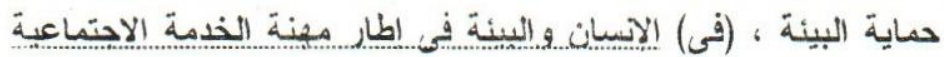

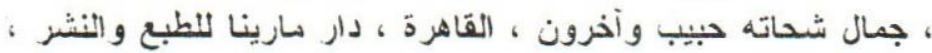
. • - محمد عبد الفتاح القصناص : الإنسان و البيينة والتنمية ، الميوتير.

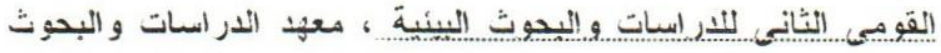

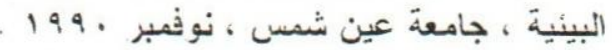

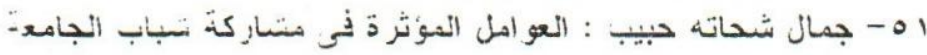

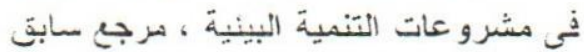

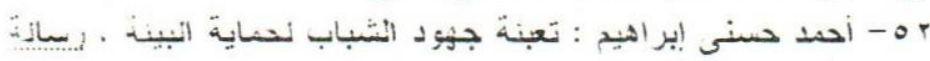

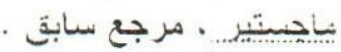


الوعي البيئي لهى طالبات الخدمة الاجنماعية بجامعة الأزهر

$$
\text { ملحق الار اسة }
$$

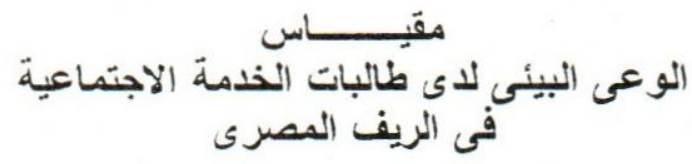

|

$$
\begin{aligned}
& \text { د / محمد محمد محموي العجوز } \\
& \text { مدرس الخدمة الاجتماعية } \\
& \text { بكلية التربية بتفهنا الأشر افت } \\
& \text { جامعة الازهز }
\end{aligned}
$$


تهلف الاستمارة التى بين يديك إلى تعرف مدى التوعى بقضايا

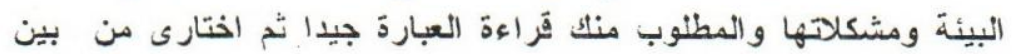

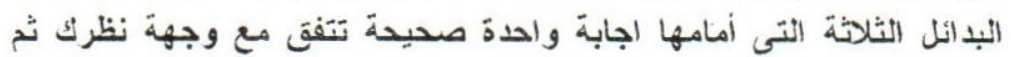

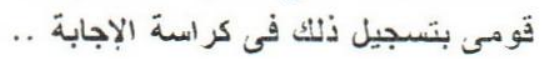

مثًال : من أسباب المشكنة السكانية فى مصر :

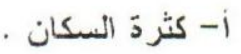

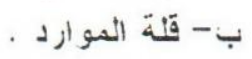

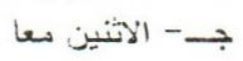

هنا يكون علئ أن تضعى علامة (V) أسفل خانة البذيل سن رقم السؤوال في كر اسة الإجابة.

و المرجو أن تكون اجابتك صادقة وتعبر عن وعيك الحقيقى ،

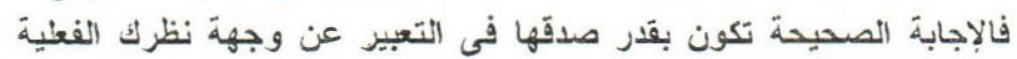

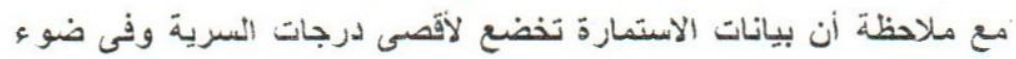

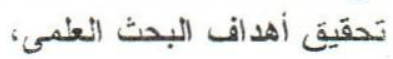

مع قبول و افز انثكر لتعاونكم الصادق معنا و السلام عليكم ورحمة الله وبركاته.

الباحث 
التوعي الببيئي لـث طلاتبات الخذمة الاجتساعية بجامعة الازهز

س ا: لكى تستفيا من هو اردنا الطبيعية أفضل استفادذّ علينا أن

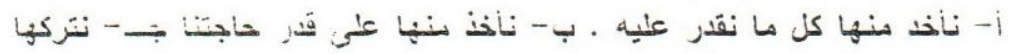

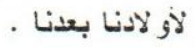

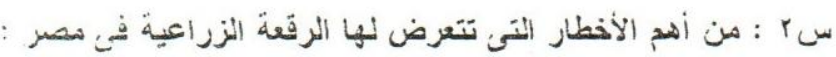

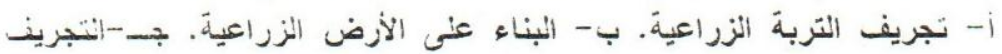
و النبناء بعا.

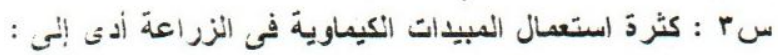

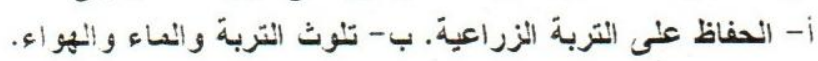

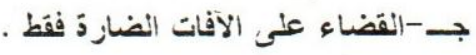

س : : سن أسباب المشكلة السكاتية في مصر :

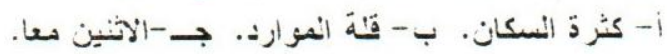

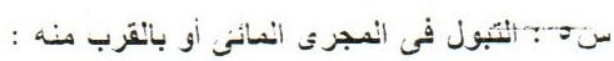

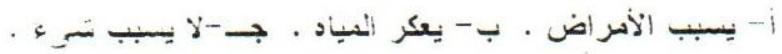

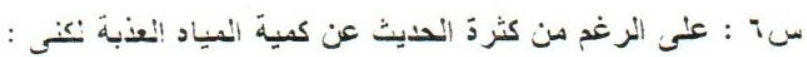

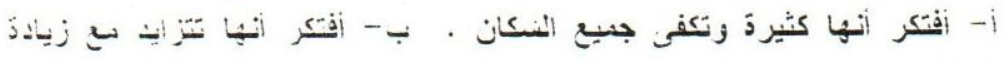

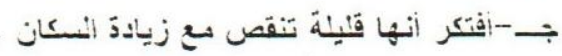

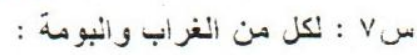

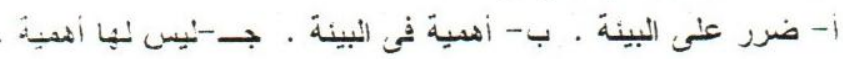

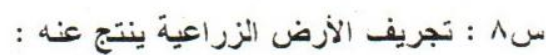

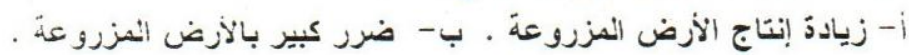

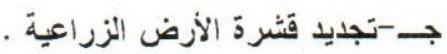

س9 : من أهداف الخذمة الاجنساعية في مجال البيئة :

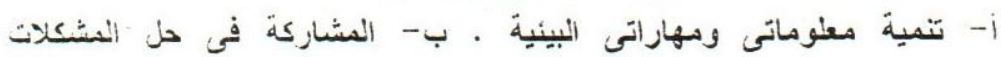
المجتنعية.

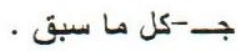
س • 1 : استمرار زيادة السكان في هصر سيؤيى إنى : 


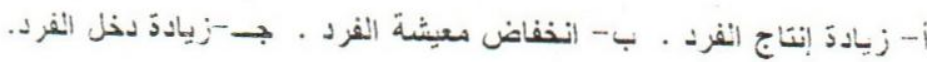

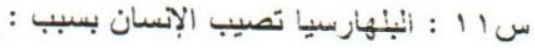

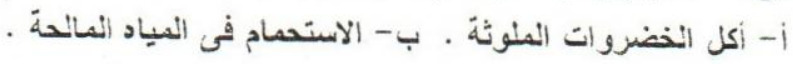
جـ-انتزول فى الترع و المصارف . سب ا : لم رأيت أبو قردان يقف فى الأرض :

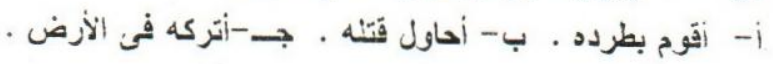

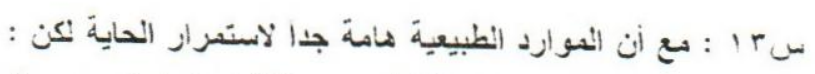

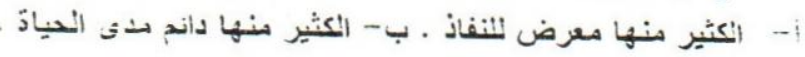

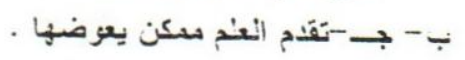

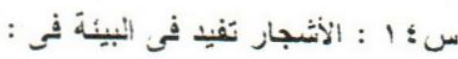

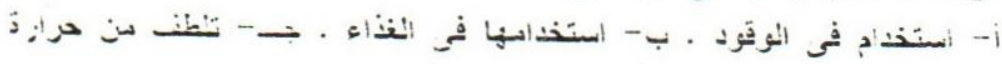
أiجنز

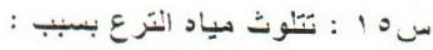

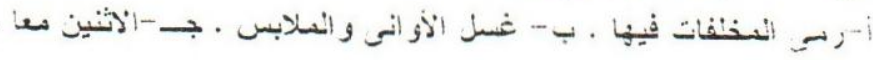

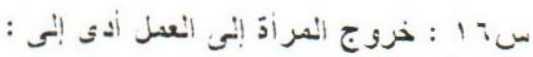

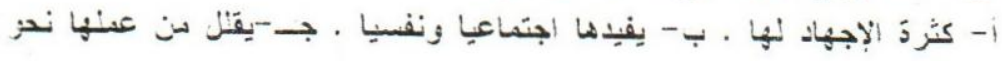
أسرنتيا

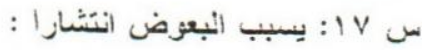

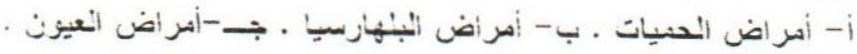

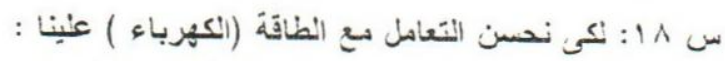

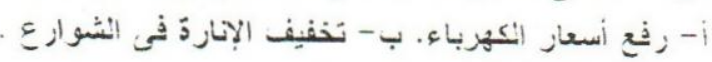

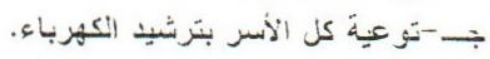

س 9 1: أفضل وسيلة للتخلص سن المخلفات الززر اعية سثل (قتش الززز) :

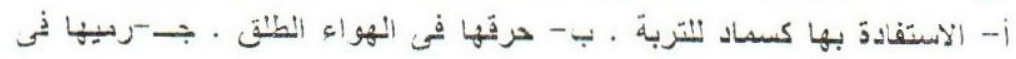

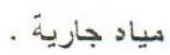

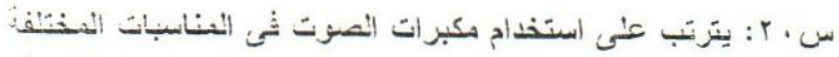

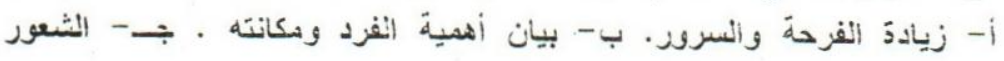


الموعي البيئي لثى طالبات الخدة الاجتماعية بجامعة الأزهر

$$
\text { بالصداع و القتق . - مأق }
$$

س ا ب : لكى نرشد استثمار كمية المياد العتبة يجب علينا :

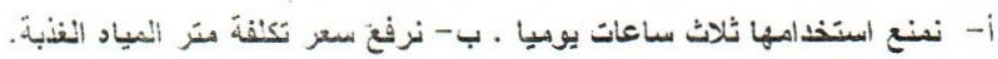

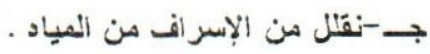

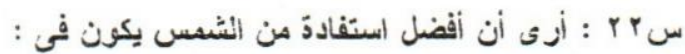

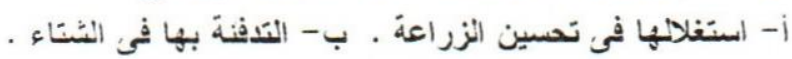
ج-تجفيف المنتجات الززاعية .

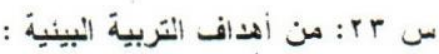

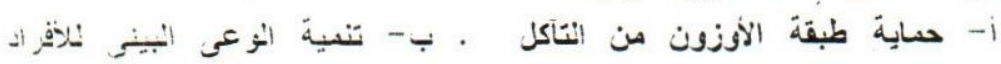
و الجنساعات. ج- الاهتصام بالزراعة الحيثية .

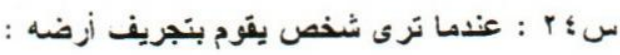

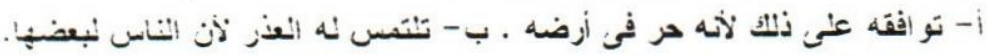

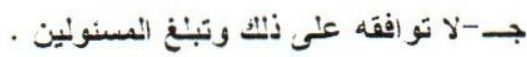
س م مب: يتلّوثر الهواءون :

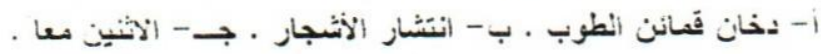

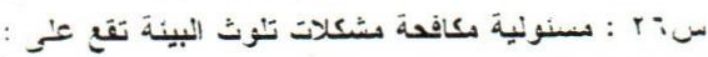

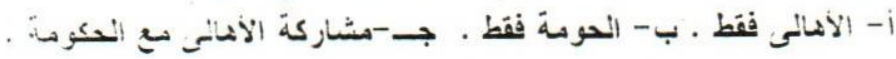

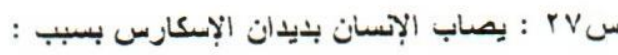

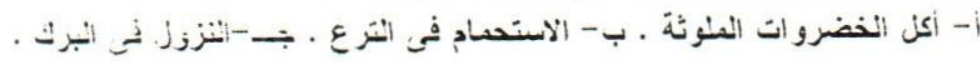

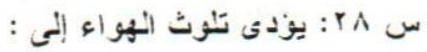

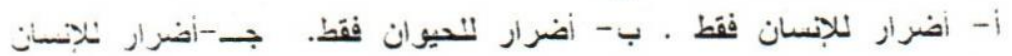
و الحيو ان. .

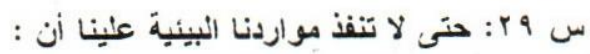

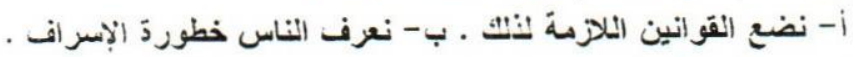

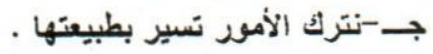


س ، r: يمكن مكافحة الأمر اض المنوطنة عن طريق :

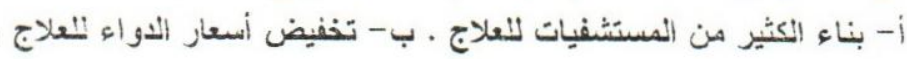
ج-توعية الناس بضررها و الموقاية منها ل.

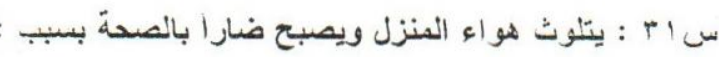

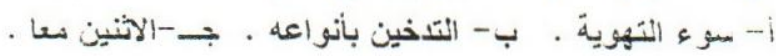

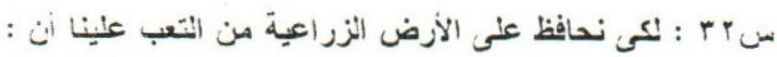

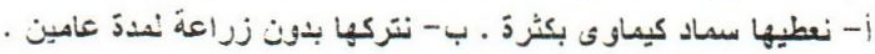

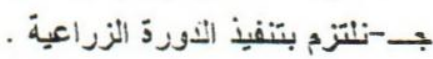

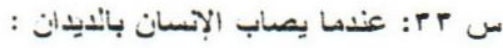

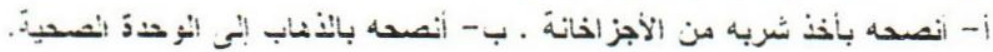

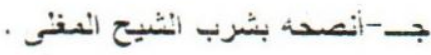

س ؛r: بكى نحل مثكلة نقص الغذاء في سصر أنث :

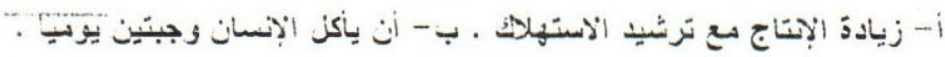

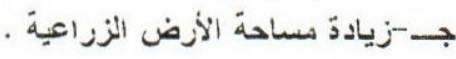

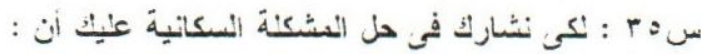

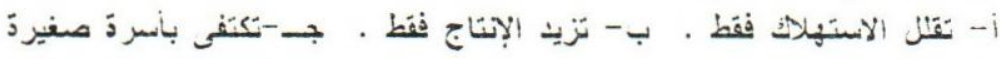
ا'عند

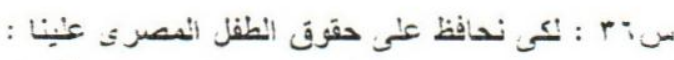

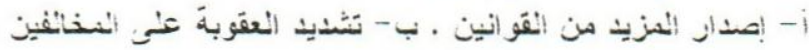

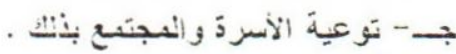

سب س : أفضل وسيثة نمقاومة الآفات الززاعية

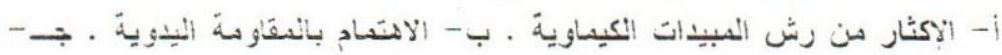

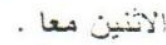

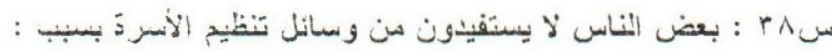

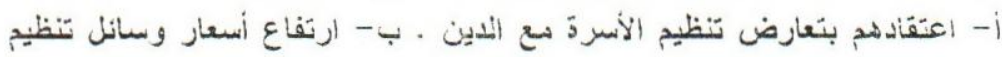

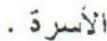

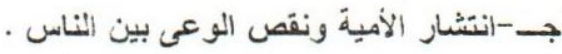

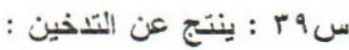


الثوعي البيئي لدى طالبات الخدمة الاجتساعية بجامعةُ الأزهر

أ- أضرار جسمية للفرد وأسرته . ب- تأثير بسيط في نخل الفري . جـ-زيادد إنتاج الفرد .

س ، : : يمكن كافحة التتخين عن طريق :

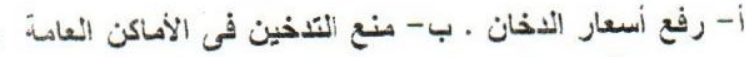

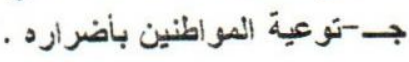

